INTERNATIONAL MONETARY FUND

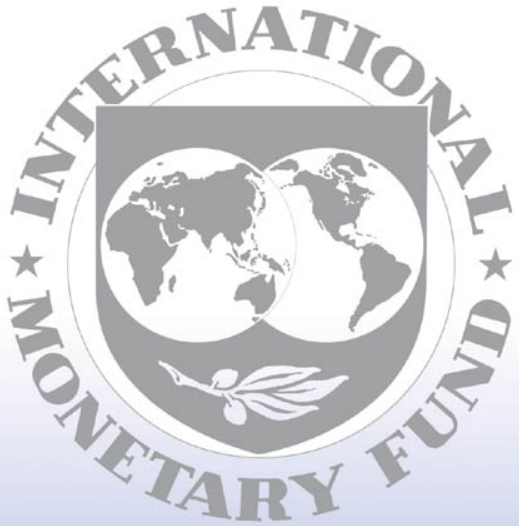

Staff

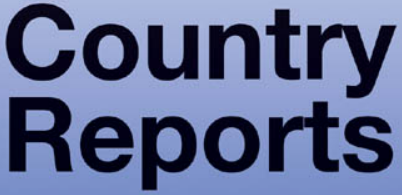




\title{
Cape Verde: 2008 Article IV Consultation and Fourth Review Under the Policy Support Instrument-Staff Report; Public Information Notice and Press Release on the Executive Board Discussion; and Statement by the Executive Director for Cape Verde
}

Under Article IV of the IMF's Articles of Agreement, the IMF holds bilateral discussions with members, usually every year. In the context of a combined discussion of the 2008 Article IV consultation with Cape Verde and the fourth review under the Policy Support Instrument, the following documents have been released and are included in this package:

- $\quad$ The staff report for the combined 2008 Article IV Consultation and the Fourth Review Under the Policy Support Instrument (PSI), prepared by a staff team of the IMF, following discussions that ended on March 19, 2008, with the officials of Cape Verde on economic developments and policies. Based on information available at the time of these discussions, the staff report was completed on June 9, 2008. The views expressed in the staff report are those of the staff team and do not necessarily reflect the views of the Executive Board of the IMF.

- A Public Information Notice (PIN) and a Press Release summarizing the views of the Executive Board as expressed during its June 30, 2008, discussion of the staff report on issues related to the Article IV consultation and the IMF arrangement, respectively.

- A statement by the Executive Director for Cape Verde.

The documents listed below will be separately released:

Poverty Reduction Strategy Paper II

Joint Staff Advisory Note on the Poverty Reduction Strategy Paper II

Selected Issues Paper

Letter of Intent sent to the IMF by the authorities of Cape Verde*

Technical Memorandum of Understanding*

* Also included in the Staff Report

The policy of publication of staff reports and other documents allows for the deletion of market-sensitive information.

Copies of this report are available to the public from

International Monetary Fund $\bullet$ Publication Services

$70019^{\text {th }}$ Street, N.W. • Washington, D.C. 20431

Telephone: (202) 623-7430 • Telefax: (202) 623-7201

E-mail: publications@imf.org • Internet: http://www.imf.org

Price: $\$ 18.00$ a copy

\author{
International Monetary Fund \\ Washington, D.C.
}


This page intentionally left blank

CInternational Monetary Fund. Not for Redistribution 


\title{
CAPE VERDE
}

\section{Staff Report for the 2008 Article IV Consultation and Fourth Review under the Policy Support Instrument (PSI)}

\author{
Prepared by the African Department \\ (In consultation with other departments) \\ Approved by David Nellor and Mark Plant
}

June 9, 2008

\begin{abstract}
Mission
Praia, March 5-19, 2008. The mission met Minister Duarte, Governor Burgo, the Finance Committee of the National Assembly, government officials, and representatives of civil society, donors, and businesses. The IMF team comprised Messrs. Leigh (head), Castro, Ronci, and Shanghavi (all AFR).

Recommendation The report recommends a waiver for the nonobservance of a continuous structural assessment criterion based on corrective actions taken, and completion of the 4th PSI review. All end-December 2007 quantitative assessment criteria were met.

Discussion topics The Article IV discussions focused on policies needed to preserve external and domestic stability:

- Keep debt on an appropriate path by anchoring fiscal policy in a medium-term perspective.

- Safeguard financial stability by reducing reliance on non-resident deposits.

- Enhance resilience to shocks by deepening structural reforms to diversify the economy and increase price flexibility.

Fund relations The Executive Board concluded the 3rd PSI review on December 21, 2007. The previous Article IV consultation for Cape Verde, which is on a 24-month cycle, was concluded in July 2006. Cape Verde has accepted the obligations of Article VIII of the IMF Articles of Agreement and maintains an exchange system free of restrictions on the making of payments and transfers for current international transactions. The de facto and de jure exchange rate arrangement of Cape Verde is a conventional fixed peg to the euro.
\end{abstract}


Executive Summary

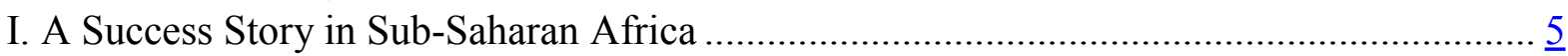

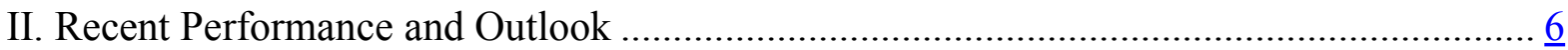

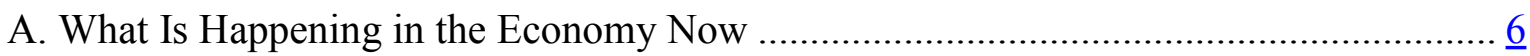

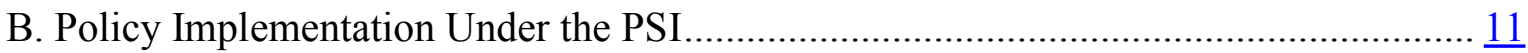

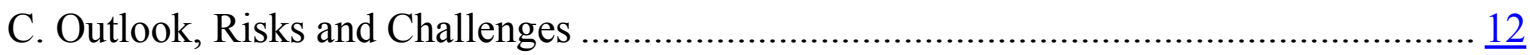

III. Policy Discussions: Sustaining the Strong Performance …………….......................... 14

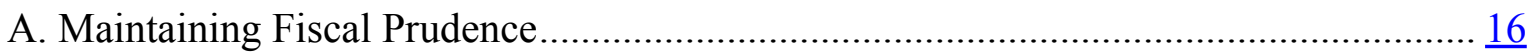

B. Preserving Financial Stability ……………………................................................

C. Maintaining Competitiveness and Fostering Private Sector Development.................... 23

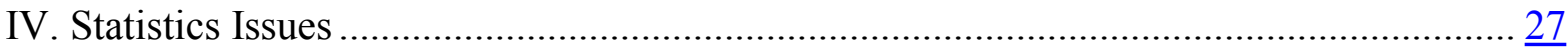

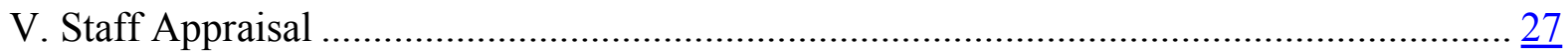

Tables

1. Selected Economic and Financial Indicators, 2006-13 …..............................................

2. Fiscal Operations of the Central Government, 2006-10 .................................................

3. Fiscal Operations of the Central Government (Percent of GDP) ………………...............

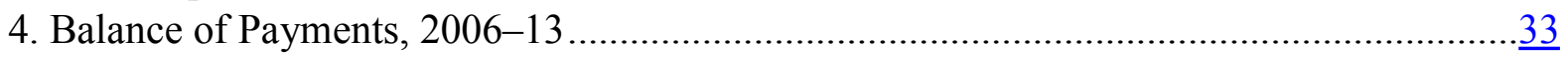

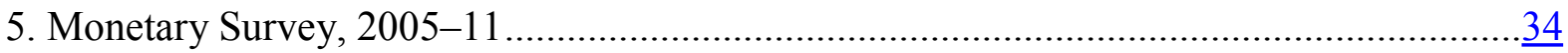

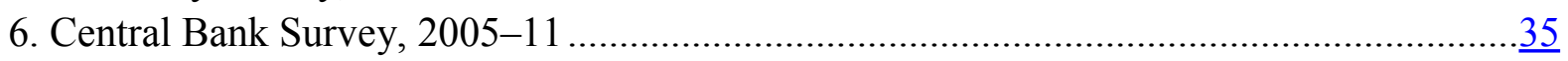

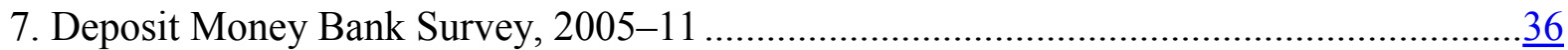

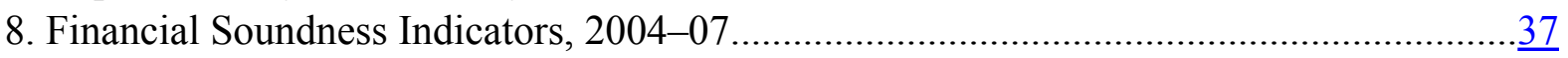

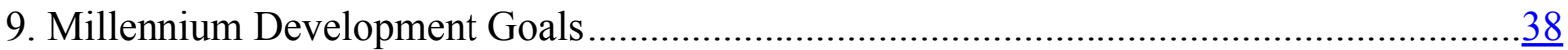

10. Proposed Work Program, 2008-09 ........................................................................

Figures

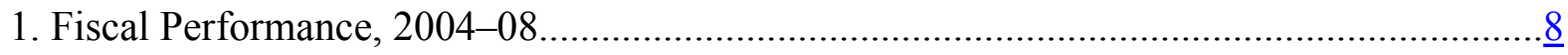

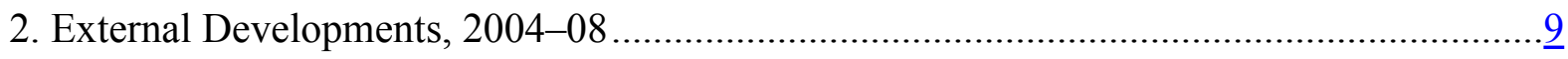

3. Monetary Developments, January 2004-December 2007 …………………………….....10

4. Cross Country Perspective in Highly Tourism Based Economies........................................18

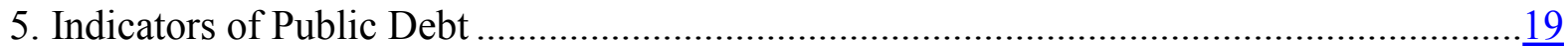

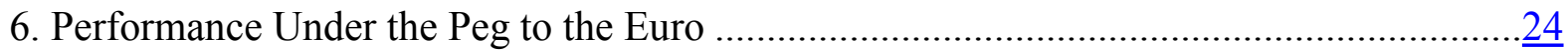


Boxes

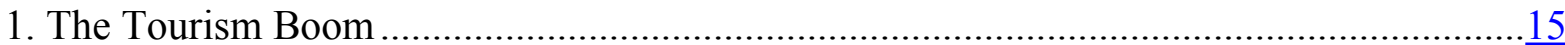

2. Remittances: A Less Reliable Hedge Against Shocks......................................................

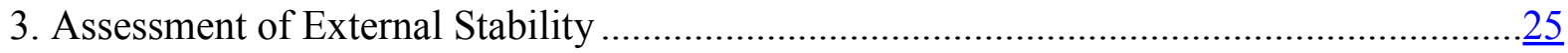

Appendix

Letter of Intent

Attachment

Technical Memorandum of Understanding .$\underline{49}$ 


\section{EXECUTIVE SUMMARY}

Over the last several years, Cape Verde has achieved a major economic transformation that is a tribute to its sound homegrown economic reform program. Real per capita GDP has increased on average by over 7 percent a year since 2001, faster than most small island economies and the average for sub-Saharan Africa. In 2006 real GDP growth reached double digits, boosted by tourism, telecommunications, and construction. Staff estimate that GDP grew by about 7 percent in 2007, and factoring in the effects from the global economic slowdown, growth is expected to moderate only slightly in 2008 as tourism and construction continue to expand. Twelve month inflation averaged about $3 \frac{1}{2}$ percent for December $2007-$ April 2008, broadly in line with inflation in the euro area.

Policy implementation under the PSI is strong. All PSI quantitative assessment criteria for end-December 2007 were met with wide margins. There was a 9 percentage points of GDP reduction in domestic public debt as revenues are ahead of the authorities' targets and expenditures are as budgeted. Official reserves are also building rapidly. Thus, domestic policies are strengthening the credibility of the exchange rate peg. Progress on structural reforms is steady, especially reforms related to public financial management, the tax system, the financial sector, and energy sector regulation. However, technical difficulties prevented implementation of the continuous assessment criterion on full application of the mechanism for setting and adjusting fuel prices. On the basis of remedial measures taken by the authorities, staff recommends granting a waiver for the missed continuous structural assessment criterion.

\section{The 2008 Article IV consultation discussions and the 4th review of the PSI focused on} policies for consolidating gains on macroeconomic stability and deepening structural reforms to sustain high growth over the medium term. The mission and the authorities reached broad understandings on measures for responding to the challenges Cape Verde faces and minimizing vulnerabilities to preserve external stability:

- A medium-term fiscal framework which accommodates the authorities' desire to increase investment in infrastructure and the energy sector while keeping debt on an appropriate path;

- $\quad$ Financial sector reforms to broaden the funding base of banks and reduce reliance on nonresident deposits, while laying the foundation for the authorities' plans for further liberalization of the capital account; and

- $\quad$ Structural reforms to foster private sector development, diversify the economy, and improve price flexibility in both goods (energy) and factor (labor) markets to support the exchange rate peg. 


\section{A SuCCESS Story In Sub-SaHaran Africa}

\section{Over the last several years, Cape Verde has achieved a major economic}

transformation. Real per capita GDP has increased on average by over 7 percent a year, faster than other small island economies and other countries in sub-Saharan Africa. The unemployment rate fell by more than 10 percentage points between 2001 and 2006. ${ }^{1}$ Cape Verde is also on track to achieve most of the MDGs by 2015, including halving the 1990 poverty level. This is remarkable for a small island economy with no natural resources. The transformation is reflected in an economy that is increasingly becoming service-based, led by tourism and commerce.

\section{Cape Verde also compares favorably} with other mature stabilizers. Growth from 2001-07 was about the average for countries that entered a PSI program, and inflation was the lowest. Although domestic debt reduction since 2001 was below the average for the PSI group, at its current rapid pace of reduction it should rival that average in a few years. The net present value of external central government debt has been reduced by 16 percent of GDP since 2001, despite the fact that, unlike most PSI countries, Cape Verde did not benefit from debt relief under the HIPC initiative and the MDRI. ${ }^{2}$ Since 2001, reserve accumulation by Cape Verde was higher than the PSI group average. In recognition of its strong performance and policy credibility, Cape Verde was accepted as a special partner of the
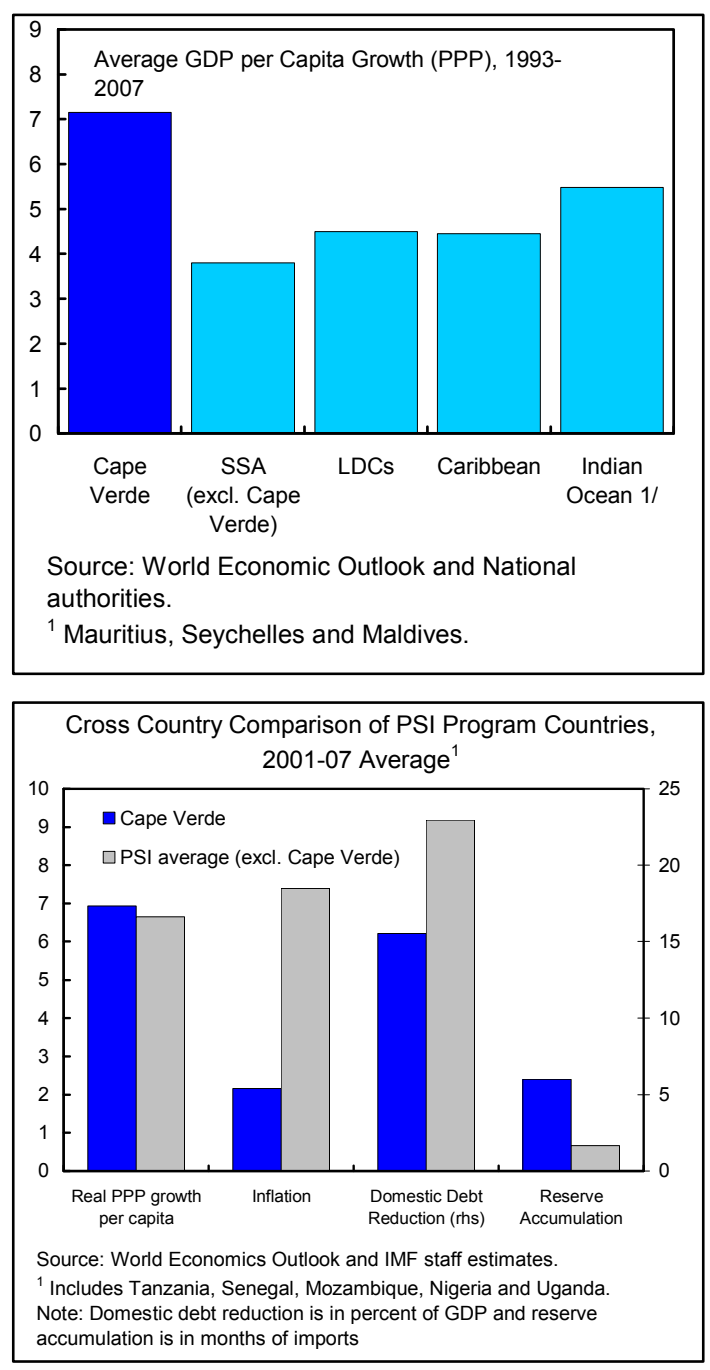
European Union in November 2007, was invited to join the WTO in December 2007, and graduated from UN least-developed country (LDC) status in January 2008 (the second in sub-Saharan Africa after Botswana and the first graduation in more than a decade).

\footnotetext{
${ }^{1}$ However, at just under 20 percent, the unemployment rate is still high, mainly because of structural factors (notably the skills mismatch in the labor market, difficulties in interisland mobility that have resulted in a segmented labor market, and possibly a high reservation wage due to remittance flows).

${ }^{2}$ Cape Verde's nominal debt to IDA, the IMF-PRGF Trust, and the AfDF at the end of 2005 was approximately US\$346 million (34 percent of GDP).
} 


\section{Cape Verde's progress owes much to a homegrown reform program that has} produced good policy outcomes:

- Lower domestic debt: Tax reforms, notably the introduction of the value-added tax (VAT) in 2004, which improved revenue buoyancy, and tight restraint on recurrent spending, helped by civil service reform, have reduced domestic debt considerably.

- A stronger external position: Good policies catalyzed high inflows of tourismrelated foreign direct investment (FDI), which are breaking past dependence on aid and remittances. Thus, international reserves were rebuilt, which enhanced the credibility of the exchange rate peg.

\section{- Greater private sector participation:}

Structural reforms were undertaken to foster competition and enhance private sector's role in the economy. Several state-owned enterprises were privatized; the government selected new management to prepare the national airline (TACV) for privatization; and the process of privatizing the ports operator (ENAPOR) is underway. Ahead of WTO accession, external tariffs were lowered. The Cape Verde Stock Exchange has been revitalized; its market capitalization is now 25 percent of GDP (from zero in 2005).

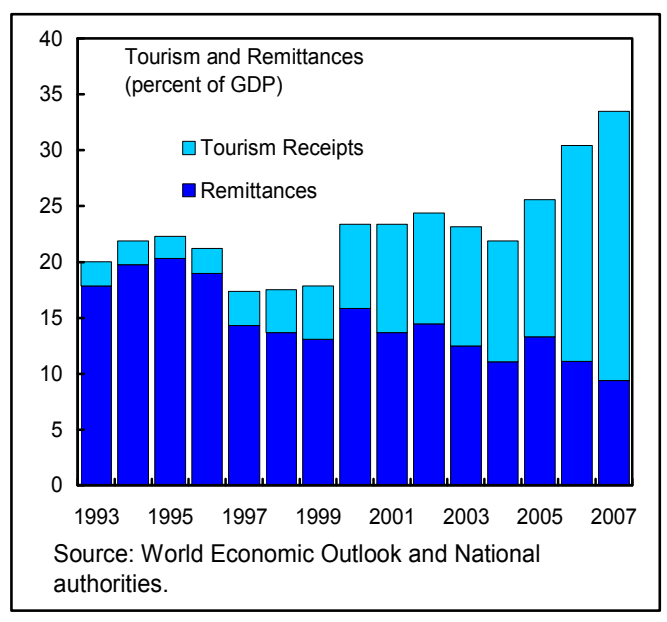

These economic achievements were facilitated by Cape Verde's political stability and enhanced governance.

\section{The 2008 Article IV consultation discussions and $4^{\text {th }}$ PSI review focused on} policies to consolidate these gains on macroeconomic stability and deepen structural reforms to sustain growth over the medium term. Discussions centered on anchoring fiscal policy in a medium-term perspective, preserving financial stability, and enhancing the economy's resilience to shocks.

\section{RECENT PERFormanCE AND OUTLOOK}

\section{A. What Is Happening in the Economy Now}

5. Economic growth is strong with moderate inflation: The real GDP growth rate peaked at 10.8 percent in 2006 , boosted by tourism, telecommunications, and construction. Based on information from the National Statistical Institute (INE), staff estimate that GDP grew about 7 percent in 2007 and, factoring in the effects of the global economic slowdown, growth should moderate only slightly to $6 \frac{1}{2}$ percent in 2008 as tourism and construction continue to expand. With the peg to the euro and the high openness allowing rapid import price pass-through, twelve-month inflation averaged about $3 \frac{1}{2}$ percent for December 2007 
April 2008, broadly in line with inflation in the euro area. ${ }^{3}$ While food and energy prices have risen, this has not led to generalized inflation partly due to lack of a strong wage indexation.

\begin{tabular}{|c|c|c|c|c|c|}
\hline \multicolumn{6}{|c|}{$\begin{array}{l}\text { Cape Verde: Contribution to Growth } \\
\text { (Annual percentage change) }\end{array}$} \\
\hline \multicolumn{6}{|c|}{200320042005} \\
\hline Agriculture and fishing & 0.1 & 0.0 & 0.0 & 0.1 & 0.0 \\
\hline Industry and energy & 0.3 & 0.7 & 0.6 & 0.5 & 0.3 \\
\hline Construction & 0.0 & 0.0 & 1.4 & 1.5 & 1.7 \\
\hline Commerce & 0.8 & 1.1 & 1.7 & 0.9 & 0.9 \\
\hline Hotels and restaurants & 0.7 & 0.5 & 0.6 & 1.5 & 0.9 \\
\hline Transport and communications & 1.1 & 1.1 & 0.0 & 3.3 & 1.4 \\
\hline Banks and insurance ${ }^{1}$ & -0.4 & -0.1 & -0.1 & 0.1 & 0.0 \\
\hline Public service & 0.9 & 0.8 & 0.9 & 1.2 & 0.6 \\
\hline Other ${ }^{2}$ & 1.1 & 0.2 & 1.4 & 1.8 & 1.2 \\
\hline GDP & 4.7 & 4.3 & 6.5 & 10.8 & 6.9 \\
\hline $\begin{array}{l}{ }^{1} \text { Net of financial intermediation } \\
{ }^{2} \text { Including housing rent, taxes c }\end{array}$ & $\begin{array}{l}\text { yes ind } \\
\text { orts a }\end{array}$ & ectly & $\begin{array}{l}\text { easur } \\
\text { er se }\end{array}$ & & \\
\hline
\end{tabular}

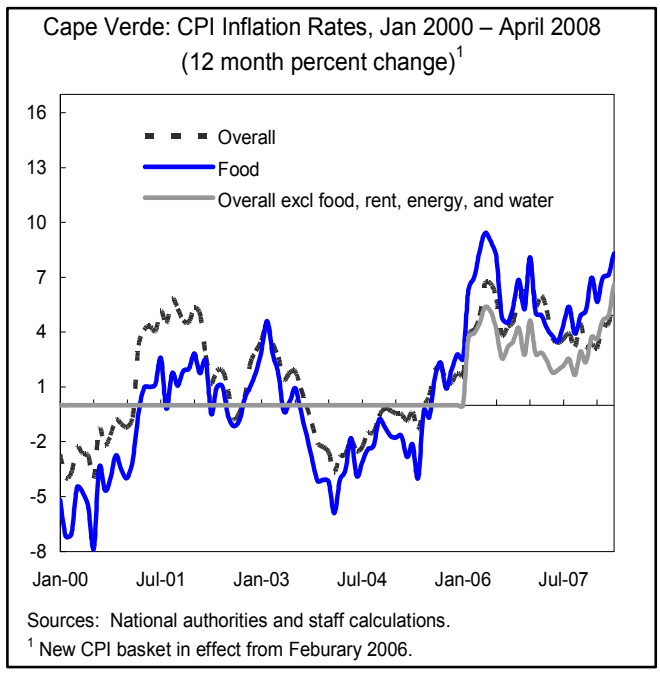

6. Fiscal policy continues to support the peg. Staff estimate that the prudent 2008 budget will ensure that domestic debt will be further reduced to 16 percent of GDP by end2008. Tax revenues are exceeding budget forecasts, reflecting not just economic growth but also improvements in tax administration; also, asset sales have surpassed expectations. These factors, together with continued expenditure restraint, have reduced the domestic debt-toGDP ratio. ${ }^{4}$ The authorities' target for domestic debt, 20 percent of GDP, was reached in 2007, two years ahead of schedule (Figure 1).

\section{The Bank of Cape Verde (BCV) continues to conduct monetary management}

appropriately. Given the peg and a largely open capital account, passive monetary management by the BCV has been setting the official policy rate consistent with its endogenous equilibrium level, which smoothes and sterilizes short-term capital flows. Reserves continue to accumulate, and while FDI-related imports have led to and financed a higher current account deficit, there are no signs of a more general increase in imports that would jeopardize the targeted increase in reserves (Figure 2). Excess liquidity has been contained by sterilization, by the new investment opportunities on the Stock Exchange following rapid development of the domestic equity market, and by growth in private sector

\footnotetext{
${ }^{3}$ A new inflation methodology was introduced in February 2008 and the time-series was recalculated from January 2005.

${ }^{4}$ Many other factors explain the strong fiscal performance including the ongoing hiring freeze. The PFM innovations in the wake of the weaknesses in data reporting for 2006 were also successful. Most notably, decentralizing the budget execution and introducing the deadline of November 30 to grant new spending commitments prevented the carryover of accounts payable from 2007 into 2008.
} 
credit (Figure 3). The buildup of government deposits at the BCV is also helping to sterilize external inflows. Thus, monetary management and fiscal prudence are both supporting the exchange rate peg and promoting external stability.

Figure 1. Cape Verde: Fiscal Performance, 2004-08 (Percent of GDP)
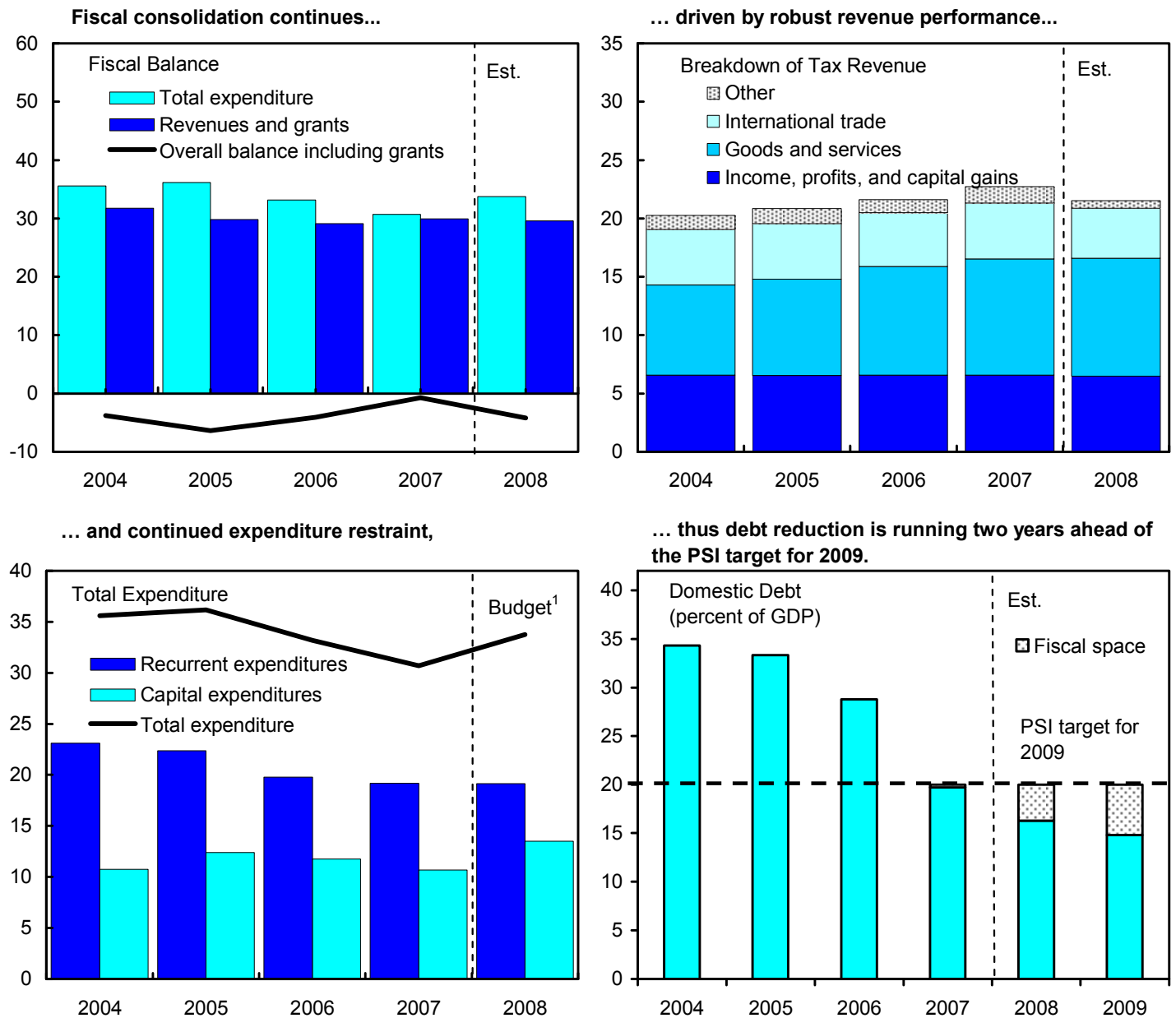

... thus debt reduction is running two years ahead of the PSI target for 2009.

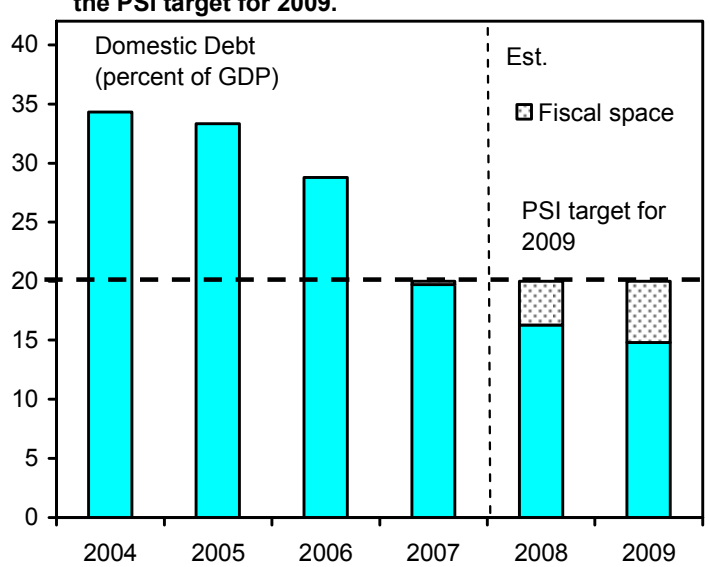

Source: National authorities and IMF staff estimates.

${ }^{1}$ The capital expenditure budget is typically underexecuted owing to capacity and donors' delays. 
Figure 2. Cape Verde: External Developments, 2004-2008
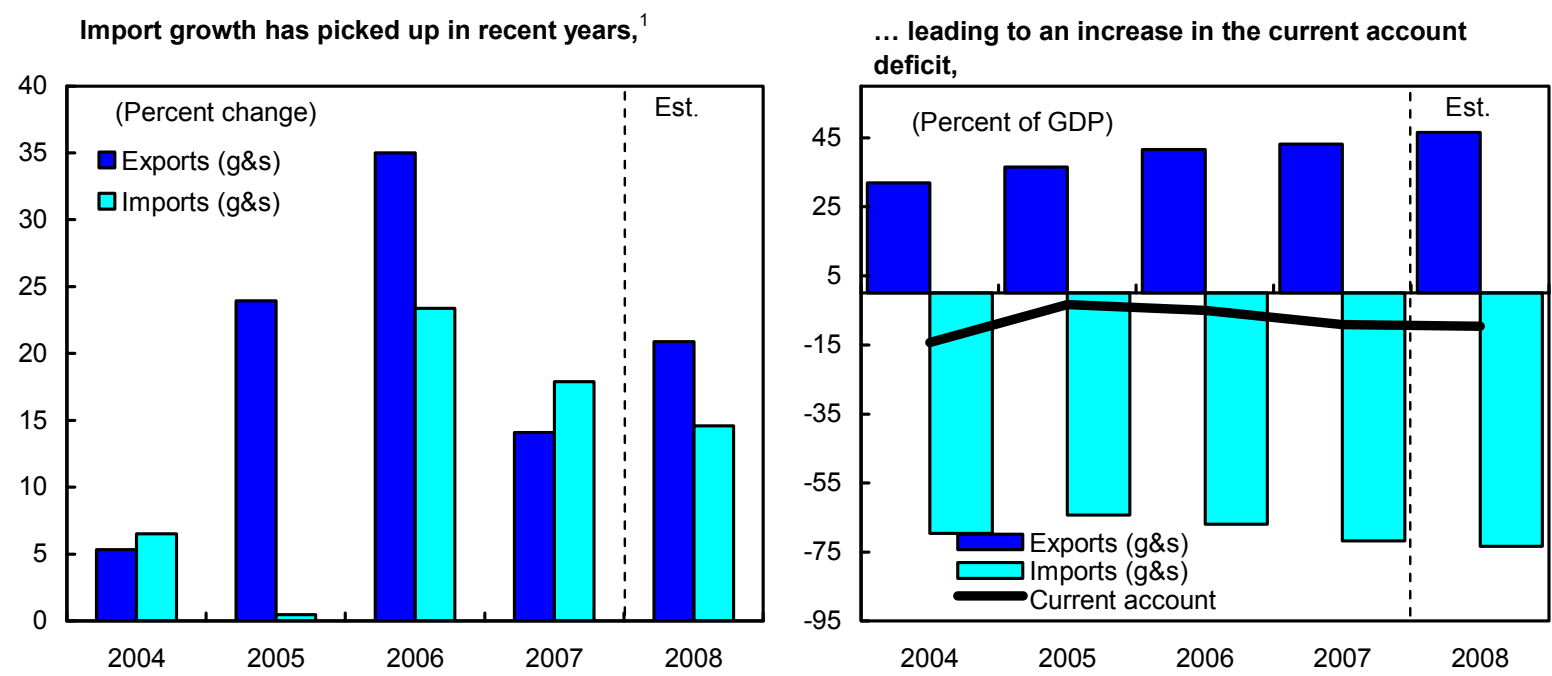

... which is more than financed by tourism-related FDI and other financial flows,..

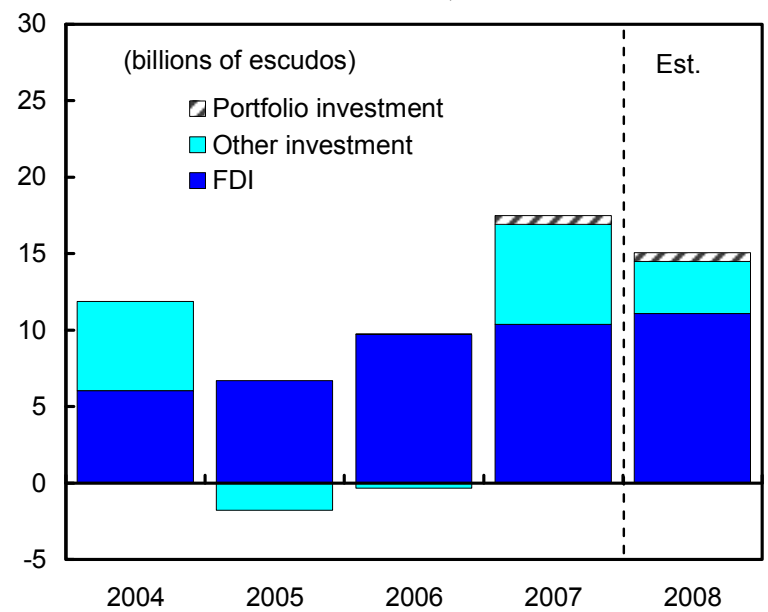

... leading to a rapid increase in gross international reserves.

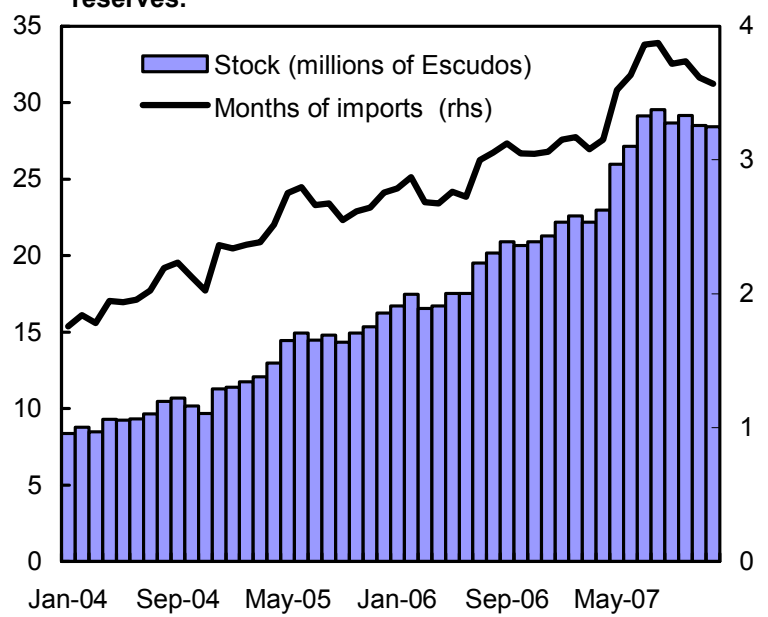

Source: National authorities and IMF staff estimates.

1. Growth in total exports in 2007 was dampened by a sharp decline in re-exports of fuel because South African Airlines stopped refueling in Cape Verde. 
Figure 3. Cape Verde: Monetary Developments, January 2004-December 2007

Banks are drawing on their excess reserves...

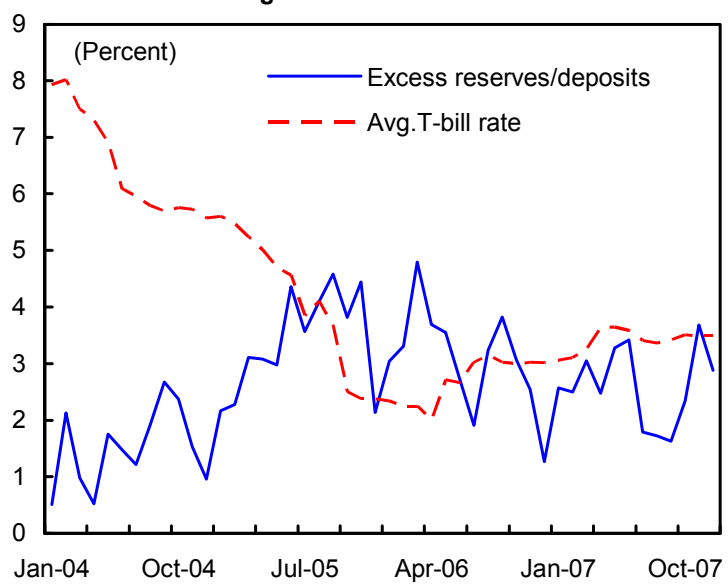

... to increase credit to the private sector...

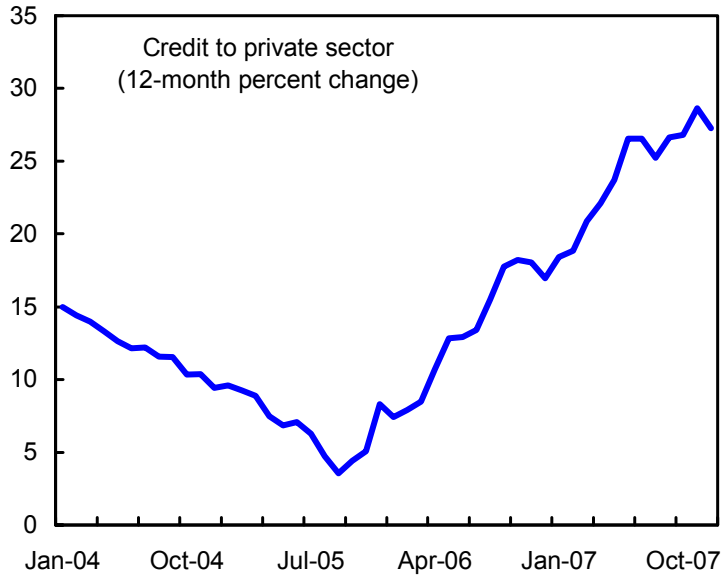

Broad money growth is tapering off...

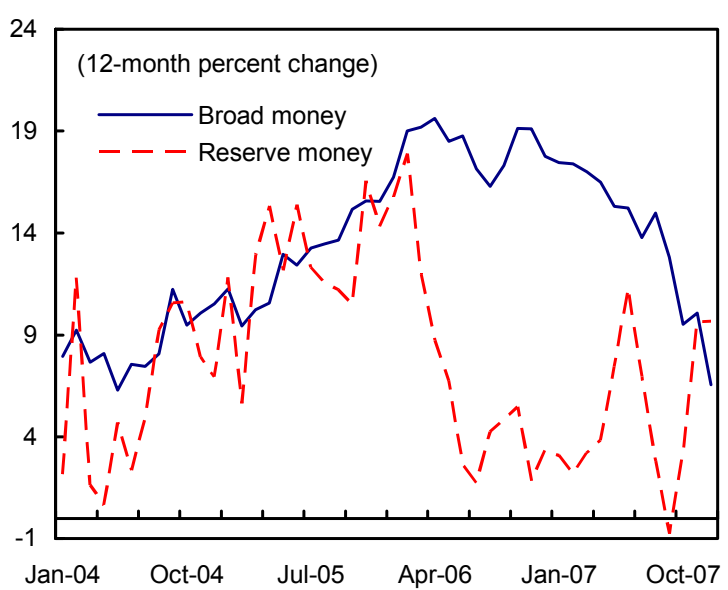

Source: National authorities and IMF staff estimates $\ldots$ and on their net foreign assets,

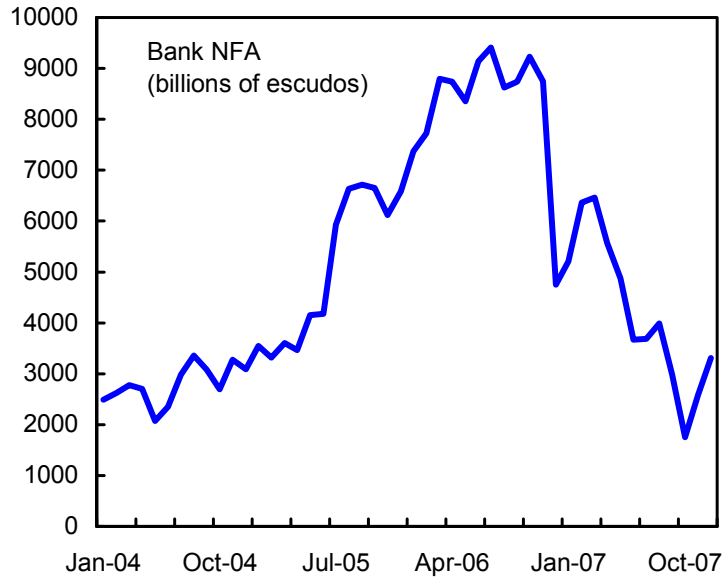

... and to purchase BCV securities.

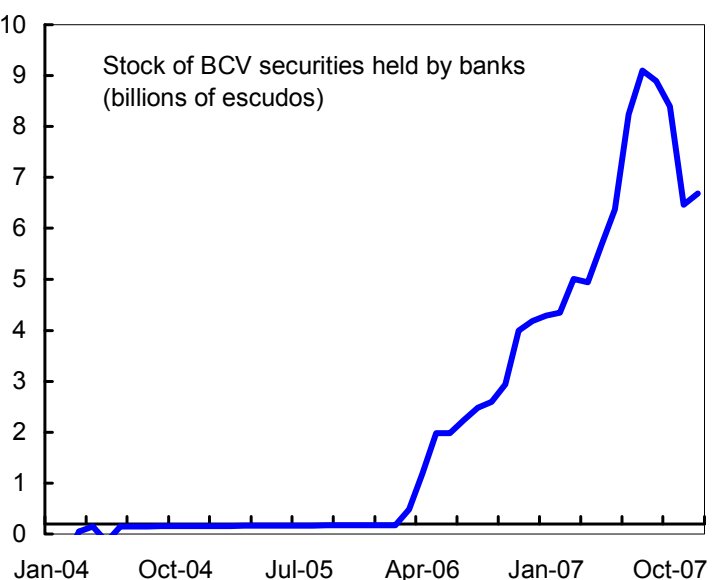

...as government bank debt declines, notwithstanding the growing money multiplier.

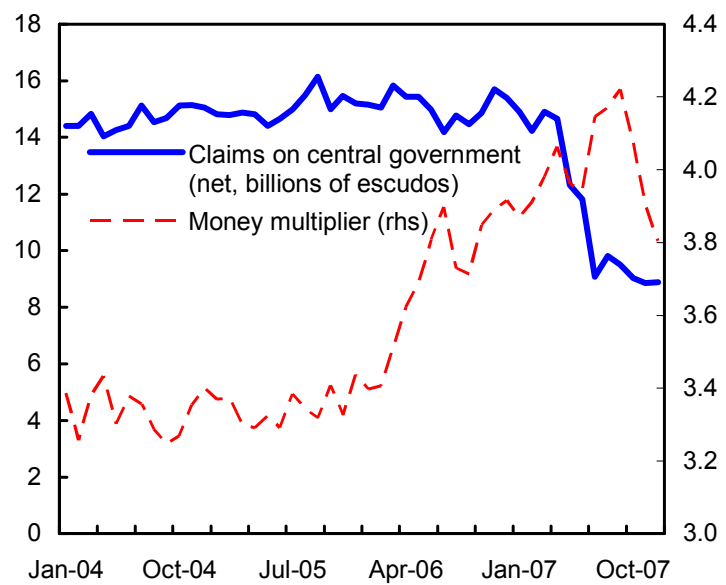




\section{B. Policy Implementation Under the PSI}

\section{All PSI quantitative assessment criteria for end-December 2007 were met with} wide margins. The ceiling on net domestic borrowing was observed by a margin of 1.8 percent of GDP reflecting a much improved public financial management system, which also prevented the accumulation of arrears. International reserves exceeded the PSI floor by about 0.2 months of imports despite some moderation in the last quarter of 2007 as FDI slowed.

\section{Despite capacity constraints, steady progress was made on implementing the structural assessment criteria: ${ }^{5}$}

- $\quad$ The authorities reported that the base utility tariffs mechanism was finalized and approved by the Economic Regulatory Agency (ARE) on March 27, 2008 and posted on ARE's website on the following day (LOI, \ 5). The goal of this structural assessment criterion in the program is to achieve full cost recovery to stop the accumulation of tariff deficits, a contingent liability. The adjustment of the final electricity price for consumers based on the new base tariffs will take into account the impact of the global food and oil price inflation on the poor and vulnerable segments of the population. ${ }^{6}$

- $\quad$ On the fuel pricing side, however, the complex cost structures of the two oil companies, Shell and Enacol, posed technical difficulties that prevented implementation of the continuous assessment criterion on full application of the mechanism for setting and adjusting fuel prices. ${ }^{7}$ To solve this problem, the Economic Regulatory Agency (ARE) took two main corrective actions: First, it adjusted fuel prices on March 25, 2008, clearing implicit subsidies owed to the oil suppliers that had accrued since the previous adjustment in October $2007 .{ }^{8}$ Second, after some delay due to lack of funding, ARE hired a consultant to develop a new fuel pricing formula (a structural benchmark for March), which is expected to be finalized and published by end June 2008. The new simplified and more transparent formula, based on a unified cost structure of the upcoming joint venture between the oil companies, will ensure regular fuel price adjustments, stop accrual of fiscal liabilities, and encourage much-needed investment in the energy sector. On the basis of these remedial measures taken by the authorities, the staff recommends granting a waiver for the missed structural assessment criterion.

\footnotetext{
${ }^{5}$ Going forward, in line with the IMF-World Bank JMAP (Informational Annex), the Fund is expected to play a subsidiary role to the Bank on both energy and labor market issues.

${ }^{6}$ The measures being considered by the government include increasing the social transfers to CVE 3,500 , expanding the eligible group, and to a lesser extent exempting grains from import duties and VAT. The estimated fiscal impact is negligible as most food items are already exempt and the increase in cash transfers will be small (around $€ 3$ per recipient).

${ }^{7}$ The assessment criterion called for application of the regulation according to which fuel prices should be adjusted every time the price of an incoming shipment of fuel imports changes by \pm 2 percent.

${ }^{8}$ Prices of gasoil and heavy fuel were raised by 12 percent, butane by 7 percent, and gasoline by 2.3 percent.
} 


\section{Important progress has also been made on implementing the structural benchmarks, despite some delays (text table).}

Cape Verde. Selected Structural Benchmarks for 2007-08 ${ }^{1}$

\begin{tabular}{|c|c|c|}
\hline Benchmark & Timing & Status \\
\hline \multicolumn{3}{|l|}{ Tax Reforms } \\
\hline Submit the new General Tax Code to the National Assembly (LOI I5). & End-Dec. 2007 & $\begin{array}{l}\text { To be implemented in } \\
\text { June } 2008^{2}\end{array}$ \\
\hline $\begin{array}{l}\text { Submit the new Code on Judicial Process to the National Assembly } \\
\text { (LOI ๆ5). }\end{array}$ & End-Dec. 2007 & $\begin{array}{l}\text { To be implemented in } \\
\text { June } 2008^{2}\end{array}$ \\
\hline $\begin{array}{l}\text { Submit the draft individual and corporate income tax bills to the National } \\
\text { Assembly ( LOI } \mid 5) \text {. }\end{array}$ & I End-Dec. 2007 & $\begin{array}{l}\text { Postponed to October } \\
2008 \text { (LOI \5) }\end{array}$ \\
\hline \multicolumn{3}{|l|}{ Financial Sector } \\
\hline $\begin{array}{l}\text { Implement the recommendations of the task-force on financial sector } \\
\text { reform. }\end{array}$ & End-June 2007 & Met in November 2007 \\
\hline $\begin{array}{l}\text { Submit to the National Assembly legislation to establish a Financial } \\
\text { Intelligence Unit (LOI } \mid 5) \text {. }\end{array}$ & End-March 2008 & Met \\
\hline $\begin{array}{l}\text { Submit to the National Assembly legislation to criminalize financing of } \\
\text { terrorism and facilitate the combating of financing of terrorism (LOI } \mid 5 \text { ). }\end{array}$ & End-March 2008 & $\begin{array}{l}\text { To be implemented in } \\
\text { June } 2008^{2}\end{array}$ \\
\hline $\begin{array}{l}\text { Submit to the National Assembly legislation to strengthen the framework } \\
\text { for combating money laundering (LOI } \mid 5 \text { ). }\end{array}$ & End-March 2008 & $\begin{array}{l}\text { To be implemented in } \\
\text { June } 2008^{2}\end{array}$ \\
\hline \multicolumn{3}{|c|}{ Public Financial Management } \\
\hline $\begin{array}{l}\text { Instituting November } 30 \text { as deadline for granting new spending } \\
\text { commitments to reduce end year payment pressure. }\end{array}$ & End-October 2007 & Met \\
\hline Finalize reform strategy for General Tax Directorate (DGCI). & End-Dec. 2007 & Met \\
\hline
\end{tabular}

\footnotetext{
${ }^{1}$ As in the Letter of Intent and Memorandum of Economic and Financial Policies of November 2007 for the $3^{\text {rd }}$ PSI review (IMF Country Report 08/37).

${ }^{2}$ Submitted to the Council of Ministers in May 2008.
}

\section{Outlook, Risks and Challenges}

\section{The near-term outlook is broadly favorable but risks are tilted to the downside reflecting the continued high oil prices and more generally the global slowdown.}

Because the Cape Verde economy is predominantly service-based and depreciation of the US dollar is containing oil prices in escudos, the oil price impact is likely to be manageable. ${ }^{9}$ Cape Verde also remains relatively unexposed to international capital markets as nonemigrant cross-border flows are relatively small. However, the global slowdown could have knock-on effects on Cape Verde's external demand (including tourism) or FDI flows. Specifically, while none of Portugal's banks that have dominant shares in Cape Verde banks have experienced difficulties so far, Cape Verde could be somewhat affected as the turmoil appears to have had some impact in the United Kingdom, Ireland and Spain which are important sources of FDI, remittances and tourism flows.

\footnotetext{
${ }^{9}$ Staff simulations suggest that if oil prices were to stay just above $\$ 100$ / barrel for the remainder of 2008 , growth will be $1 / 4-1 / 2$ percentage point lower.
} 
12. Staff expect strong economic performance over the medium term. Growth is projected to average about $63 / 4$ percent through 2013 , underpinned by tourism, FDI, and public investment. Cape Verde is expected to consolidate its position among the highlytourism based economies (Box 1). The current account deficit will likely widen and be financed increasingly by the strong FDI flows (non-debt creating) unlike a decade ago, when debt and remittances financed the balance of payments. Emigrant remittances are expected to taper off as income in Cape Verde grows faster than in the countries where its emigrants reside and emigration declines. Staff's empirical analysis also suggests that remittances are becoming more procyclical and thus less reliable as a shock absorber (Box 2). On concessional financing, in preparing for the transition from LDC status, the authorities reached out extensively, and most donors confirmed that graduation will not lead to an abrupt end to concessional aid. Continued fiscal restraint is envisaged over the medium term and the revenue losses of WTO accession and EU- economic partnership agreement will be limited and gradual. ${ }^{10}$

\section{Balance of Payments Source of Financing, 1995-2007}
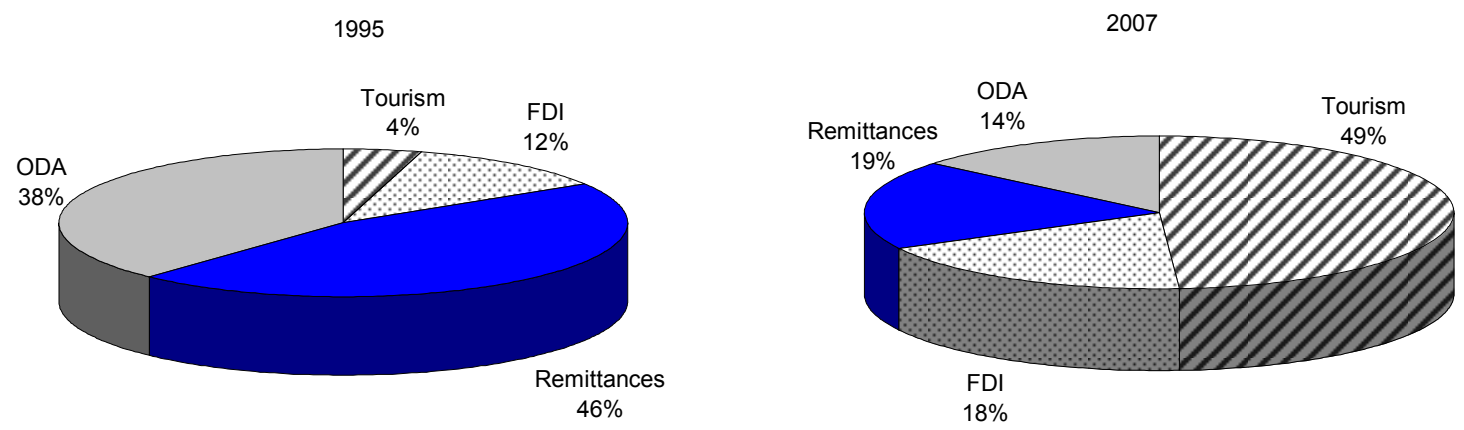

Source: National authorities

\section{This said, Cape Verde faces old vulnerabilities and emerging challenges:}

- Infrastructure bottlenecks still constrain growth. Continued growth in the tourism sector will require large-scale investments in transportation and energy infrastructure. Making use of the fiscal space to increase capital expenditures, while maintaining debt sustainability, poses a challenge.

- The financial sector still relies on nonresident deposits. These deposits constitute about 40 percent of total bank deposits making the banking system's funding base significantly reliant on them. The annual growth rate of the stock of non-resident deposits (NRD), although still respectable at about $6 \frac{1 / 4}{4}$ percent, has slowed in recent years. However, there are doubts about how interest-sensitive these deposits are. While banks have been

\footnotetext{
${ }^{10}$ The applied duty rates are already below the bound rates in Cape Verde's WTO commitments; the rationalization of exemptions will broaden the tax base and revenue from non-exempt imports are expected to rise over the medium term as tourism activity grows.
} 
pressured to launch new savings products to continue to attract NRDs in a context of declining rates, ${ }^{11}$ the home bias and historical resilience of these remittance-based inflows significantly minimize the risks of a reversal. Thus, it remains unclear the extent to which the NRDs are a potential capital account-based source of vulnerability and hence warrant close monitoring.

- Cape Verde's export base is narrow. The economy is vulnerable to a weakening of international demand for tourism, especially given the scarcity of natural resources as alternative exports. To date structural reforms have not been sufficiently broad-based to sustain high growth in the long term, and there are difficulties in adjusting to demand shocks given the ongoing specialization in tourism and the limited price and wage flexibility. ${ }^{12}$ Limiting the vulnerability associated with this specialization, diversifying sources of growth, and increasing the economy's flexibility to buffer against shocks pose a challenge.

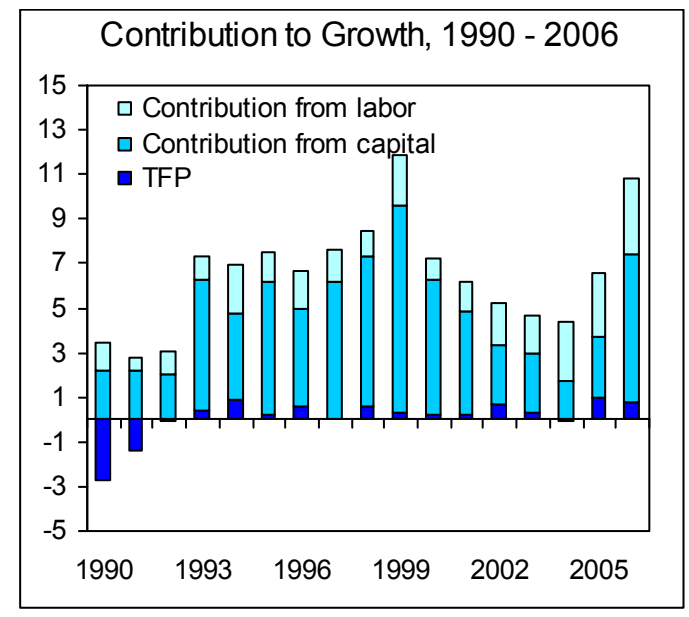

\section{Policy Discussions: Sustaining the Strong Performance}

\section{The discussions focused on the policies needed to maintain Cape Verde's} impressive macroeconomic performance and stability in the face of changing balance of payments flows.

- $\quad$ Guided by external stability, the mission discussed a package of measures to respond to these challenges and minimize vulnerabilities to preserve macroeconomic stability. These include the use of a medium-term fiscal framework to accommodate the authorities' plans to increase infrastructure and energy sector investment while keeping debt on an appropriate path; financial sector reforms to broaden the funding base of banks and reduce reliance on non-resident deposits, while further liberalizing the capital account; and structural reforms to diversify the economy and increase price flexibility in both goods and factor markets to enhance resilience to shocks.

\footnotetext{
${ }^{11}$ While banks are competing to attract NRDs by raising rates on these deposits at the margin, average interest rates across all maturities continue to decline.

${ }^{12}$ Capital deepening has been the key driver to growth in Cape Verde while the contribution from total factor productivity (TFP) (structural reform driven) has been historically small. The growth accounting here assumes a Cobb-Douglas production function $Y=A K^{\alpha} N^{1-\alpha}$, where $Y$ is aggregate output, $A$ is total factor productivity, $K$ is capital, and $N$ is labor.
} 
- The authorities concurred, in particular on the changing balance of payments, and welcomed the mission's work on Cape Verde through cross-country analysis of highlytourism-based economies. Nevertheless, they emphasized that in some areas capacity constraints may hamper policy implementation and in this context reiterated that they will continue to need technical assistance from the Fund in a range of areas. In the attached Letter of Intent (Appendix), the government affirms its commitment to the policy goals described in its recent Memorandum of Economic and Financial Policies (MEFP) (IMF Country Report 08/37) and updates its plans to meet those goals.

\section{Box 1. The Tourism Boom ${ }^{1}$}

Cape Verde is the fastest-growing tourism market among the highly-tourism-based economies (HTBEs). It was recently discovered as a new frontier for European tourism. Travel exports have grown by more than 30 percent annually on average for more than a decade, far outpacing other HTBEs. The development of the tourism sector has been a success for Cape Verde with obvious growth benefits and poverty reduction potential.

\section{Country-specific factors explain} the comparative advantage in tourism: convenient location, good position to harness the overflow of Mediterranean tourism, a favorable sociopolitical situation, macroeconomic stability, and good governance.

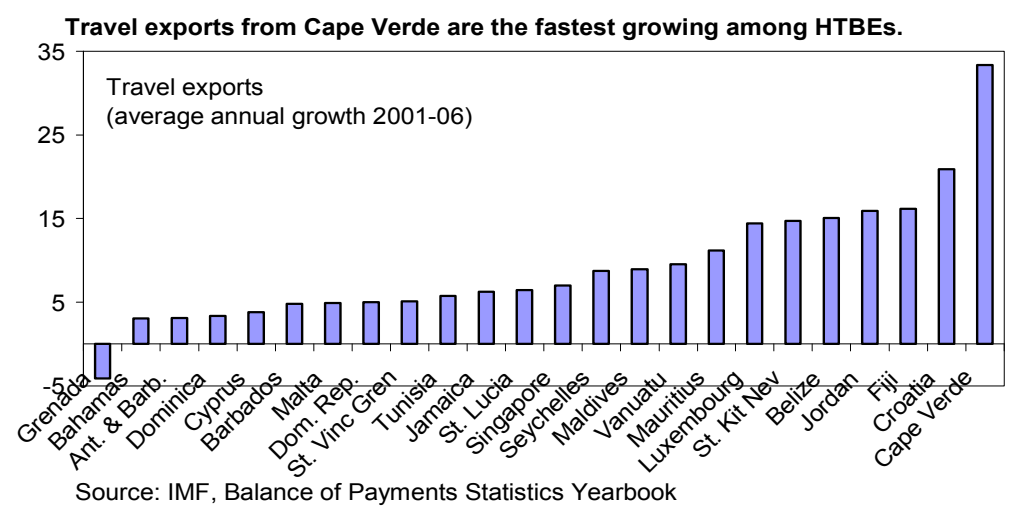

However, specialization in tourism and increasing openness will bring high volatility.

Dependence on a single export means that shocks to demand for that export will propagate throughout the entire economy. The tourism sector in Cape Verde is not an enclave and is becoming a conduit for external shocks and the business cycle is becoming synchronized with tourism originator countries.

Cross country analysis shows that output volatility tends to increase as economies become more HTBE. HTBE also have business cycles with higher amplitude and longer duration, so large buffers are needed to smooth consumption during longer and deeper contraction phases. However, countercyclical policies are not available to Cape Verde because it has a passive monetary policy under a peg, and the small fiscal multipliers with the high import leakage. Thus, as it becomes more and more an HTBE, Cape Verde would need buffers through higher reserves and fiscal space.

${ }^{1}$ Selected Issues, Chapter 1.

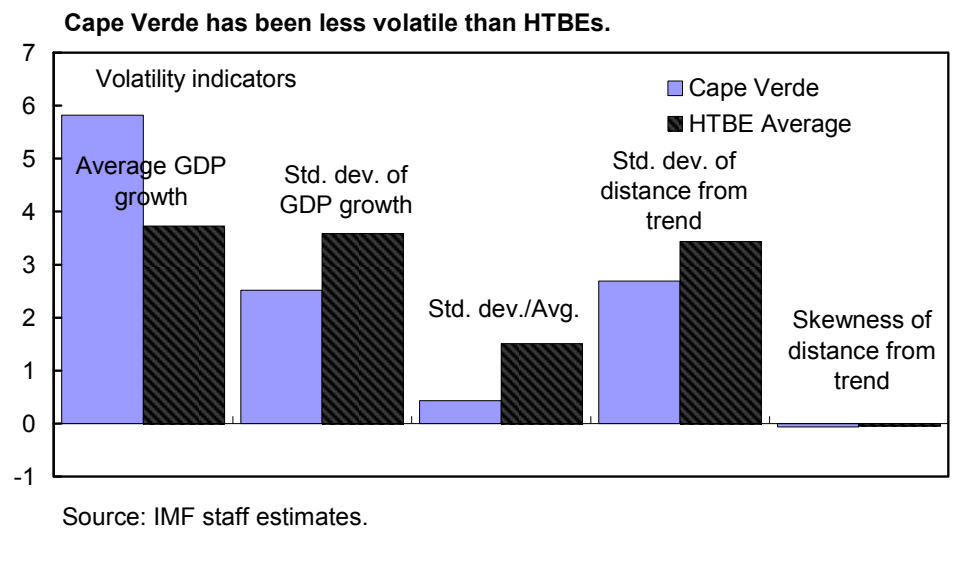




\section{A. Maintaining Fiscal Prudence}

Staff and the authorities agreed on the need to articulate a medium-term fiscal strategy. This would provide room for the authorities' planned increase in infrastructure spending to sustain the tourism boom and ensure that the upcoming tax reforms are broadly revenue-neutral.

\section{The mission and the authorities agreed on the need to orient fiscal policy in a} medium-term perspective.

- $\quad$ Staff noted that the reserves target should anchor medium term fiscal policy. By constraining domestic demand to build up foreign reserves, fiscal policy contributes directly to the credibility of the peg. The use of the reserves target to anchor medium-term fiscal policy is also consistent with keeping public debt along an appropriate path. The recent decline in the country risk premium largely reflects better fiscal fundamentals and the associated rise in official reserves. Staff's cross-country analysis shows that while growth has been higher than average and inflation lower,

\begin{tabular}{|c|c|c|c|c|}
\hline \multicolumn{5}{|c|}{ Adequacy of Central Bank's Reserves (average) } \\
\hline & 1999-04 & $2005-07$ & $2008-13$ & 2013 \\
\hline & \multicolumn{4}{|c|}{ (percent) } \\
\hline Reserves/ Base money & 43 & 99 & 140 & 144 \\
\hline \multirow[t]{2}{*}{ Reserves/ Short term external debt 1 / } & 62 & 126 & 169 & 172 \\
\hline & \multicolumn{4}{|c|}{ (months of imports) } \\
\hline Reserves/ Prospective Imports & 1.6 & 3.1 & 3.9 & 4.2 \\
\hline Reserves/ Prospective Permanent Imports 2/ & 1.8 & 4.0 & 5.5 & 5.9 \\
\hline \multicolumn{5}{|c|}{$\begin{array}{l}\text { Source: National Authorities, staff estimates and projections. } \\
\text { 1/ Short term debt based on remaining maturity. } \\
\text { 2/ Permanent imports equal imports minus one-half of FDI and of tourism exports. }\end{array}$} \\
\hline
\end{tabular}
Cape Verde's public debt-to-GDP ratio is one of the highest among highly-tourism-based economies, and its reserves are below average (Figure 4). Thus, Cape Verde needs larger buffers in the form of higher international reserves and fiscal space (Box 1), especially in the context of declining reliability of remittances to smooth consumption and hedge against macroeconomic shocks (Box 2).

- The authorities concurred and stated that their objective is to increase reserves by about 0.1 month of prospective imports annually reaching over 4 months by 2013 . This is appropriate as it is equivalent to about 6 months expunging FDI-related imports, and 172 percent of short-term debt, supported by continued fiscal restraint. 
16. Staff and the authorities reached understandings on the operational aspects of medium-term fiscal policy. Thus, the authorities agreed to include a new structural measure in the PSI program on submitting a simplified medium-term fiscal framework (MTFF) to the Council of Ministers along with the 2009 budget proposal and publishing it on the Ministry of Finance website (LOI, 98$).{ }^{13}$ Implementing this MTFF would require accelerating public financial management (PFM) reforms to enhance implementation capacity and thereby improve the quality of public investment. Given the fiscal space created by the larger-thanexpected reduction in domestic debt in 2007, the envisaged medium-term baseline scenario projects that the fiscal deficit will average about 5 percent of GDP through 2013, bringing the total nominal debt-to-GDP ratio from 67 percent at the end of 2007 to 49 percent by $2013 .{ }^{14}$ This scenario assumes that, since the authorities have already reached their domestic debt target of 20 percent of GDP, they will keep the ratio below that over the medium term to buy "policy insurance" against shocks and to support the peg. To provide room for the authorities' planned increases in infrastructure expenditures to sustain the tourism boom and reduce poverty, an alternative scenario was developed in which capital expenditures on infrastructure increase by further 2 percent of GDP annually for five years. The results show that even under this scenario, the risk of debt distress remains low (Figure 5). ${ }^{15}$ Furthermore, the authorities' envisaged reserve buildup is preserved ( $\$ 15) .{ }^{16}$ Moreover, recent steps taken by the authorities to improve the energy pricing mechanism coupled with their broader energy sector reform plan (LOI, $\uparrow 12$ ), will also help reduce fiscal risks over the medium term and potentially contribute fiscal space toward infrastructure development. The MTFF will also be a tool to ensure that the upcoming tax reforms and the rationalization of tax exemptions are implemented in a broadly revenue neutral fashion. The authorities also noted that operationalizing the MTFF will enhance the implementation of the new Poverty Reduction Strategy (PRSP-2), which was finalized in May 2008.

\footnotetext{
${ }^{13}$ A simplified MTFF indicates total annual revenues, expenditures, domestic financing, and external financing for the next three years.

${ }^{14}$ The domestic debt reduction path in this report is more ambitious than envisaged in the last staff report (Country Report 08/37).

${ }^{15}$ The PSI program's US\$35 million ceiling on nonconcessional external borrowing and government guarantees gives the authorities room to finance growth-enhancing energy and infrastructure projects. This ceiling remains unused owing partly to capacity constraints on debt management (LOI, $\uparrow 9$ ) and partly to the continued availability of concessional financing, including from IDA and Portugal.

${ }^{16}$ See 2007 DSA (Country Report 08/37, Staff Supplement).
} 
Figure 4. Cape Verde in Cross-Country Perspective, Based on Highly Tourism Based Economies (Average for $2000-06^{1}$ )
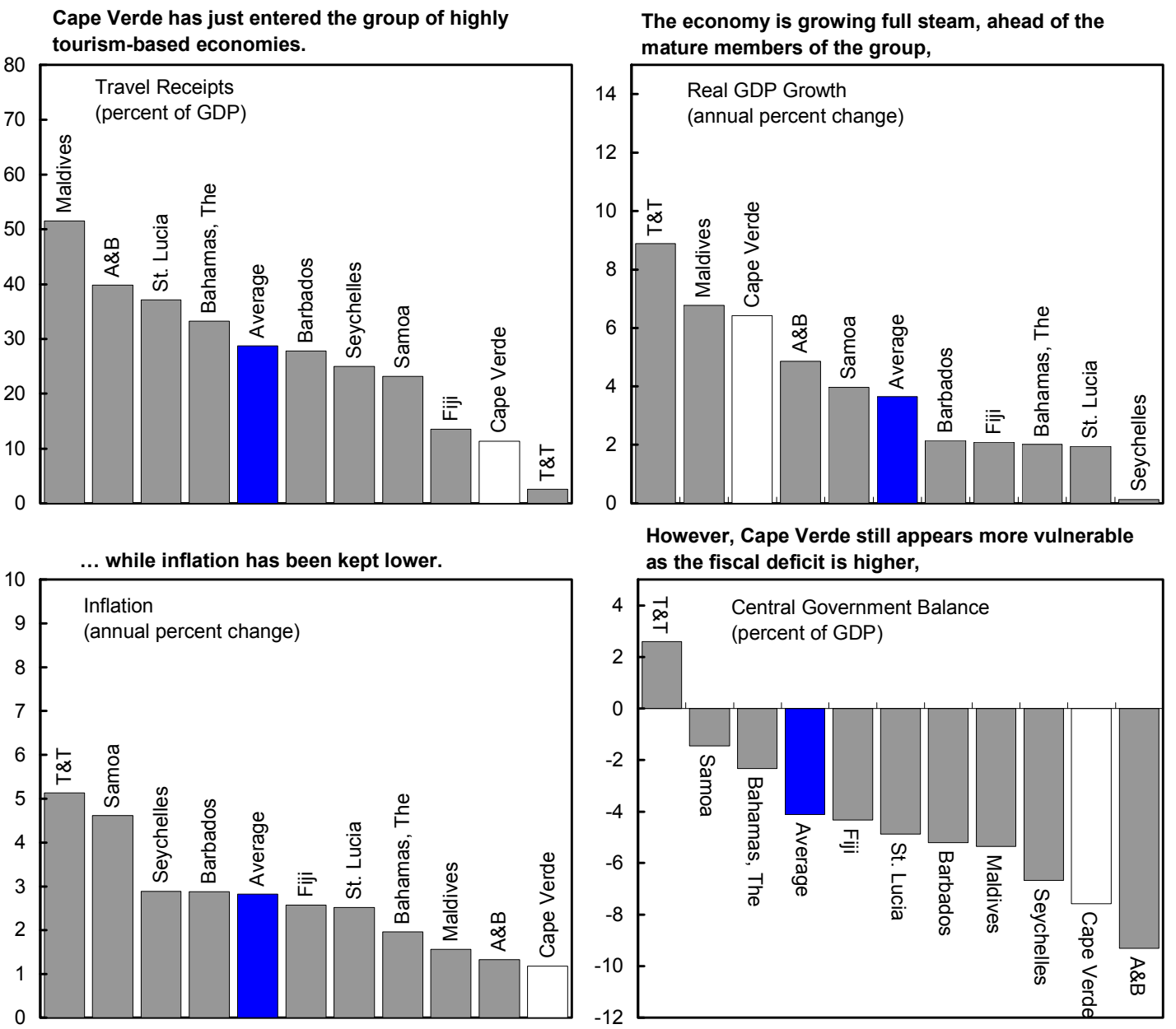

However, Cape Verde still appears more vulnerable as the fiscal deficit is higher,

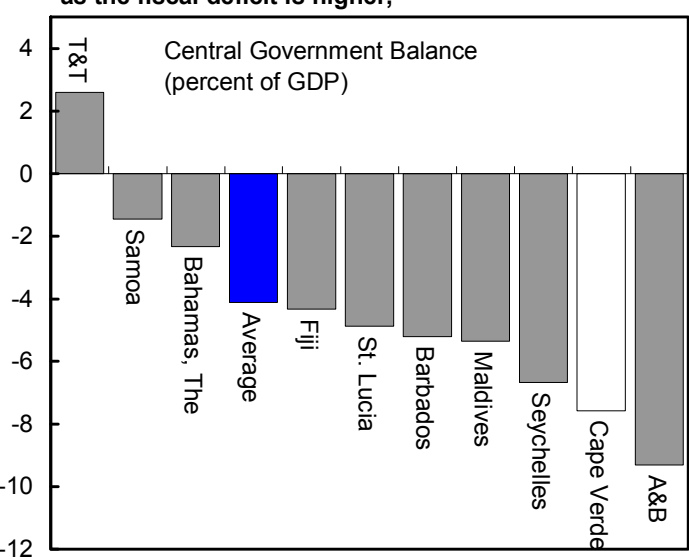

... the debt ratio is also higher,..
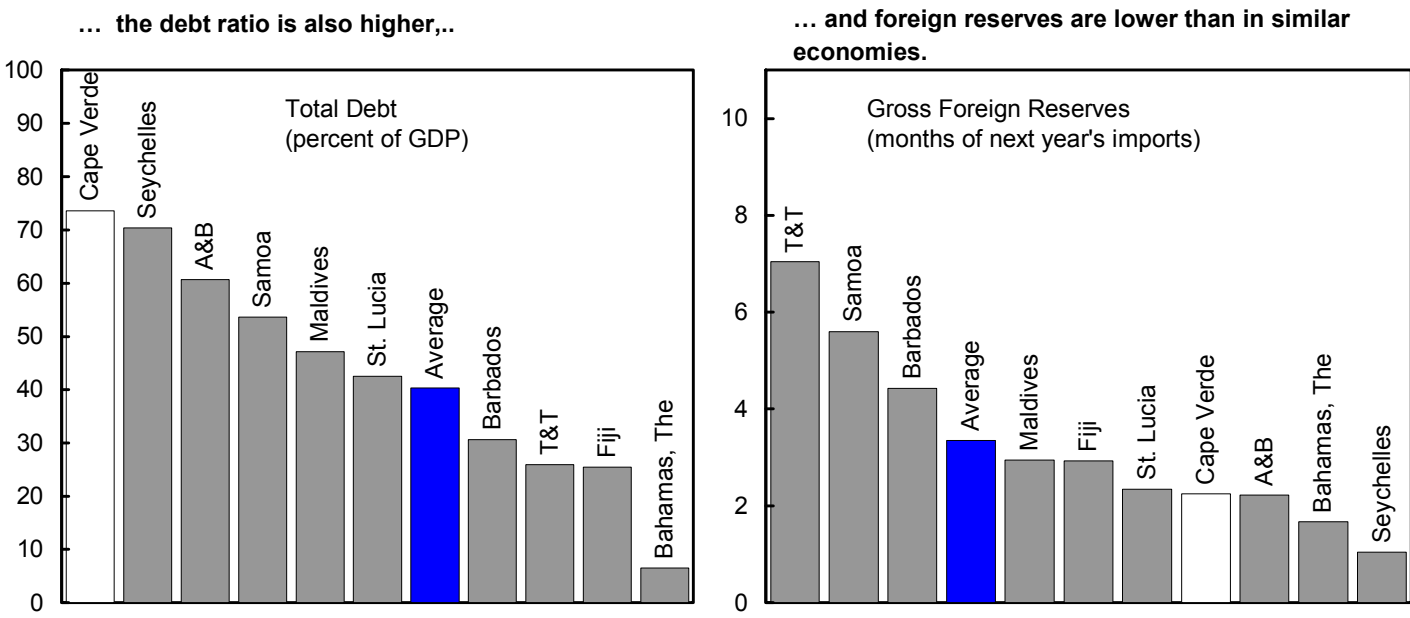

Source: World Economic Outlook and International Financial Statistics.

${ }^{1}$ A\&B: Antigua and Barbuda; T\&T: Trinidad and Tobago. 
Figure 5. Cape Verde: Indicators of Public Debt Under Alternative Scenarios, 2007-27
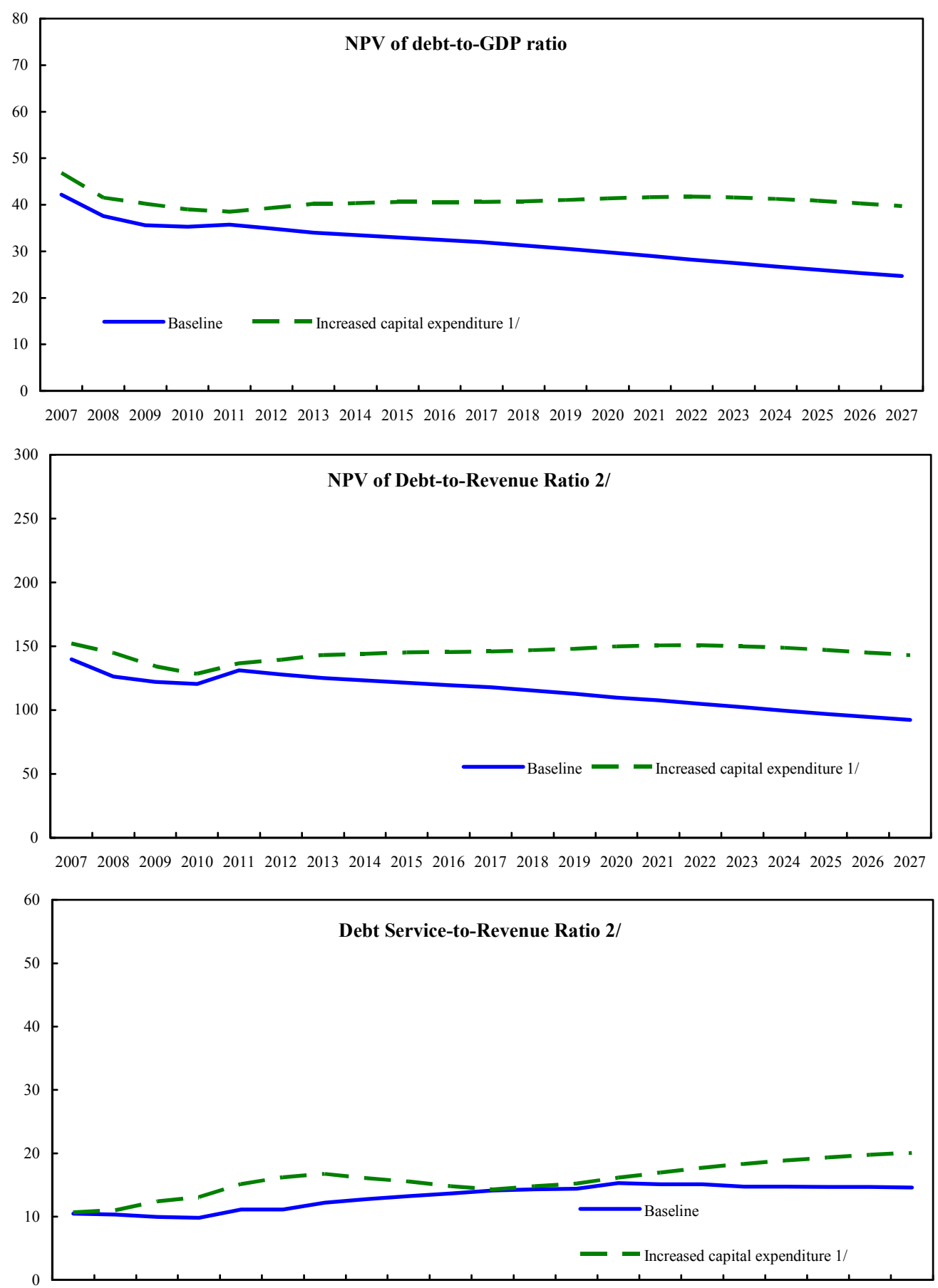

200720082009201020112012201320142015201620172018201920202021202220232024202520262027

Source: Staff projections and simulations.

1/ See 2007 DSA (IMF Country Report 08/37)

2/ Revenue including grants. 


\section{Box 2. Remittances: A Less Reliable Hedge against Macroeconomic Shocks ${ }^{1}$}

The changing financing structure of the balance of payments calls for a closer look at the volatility of worker remittances and their role as a shock absorber. Historically, remittances from the Cape Verdean diaspora have constituted a large share of external financing. Staff's previous analysis (WP/06/132) found that remittances from Europe were largely driven by altruistic motives and thus acted countercyclically in smoothing consumption, while flows from the United States may have partly been motivated by investment in Cape Verde.

Indeed, remittances have been less volatile than foreign direct investment (FDI) and exports, and only slightly more volatile than official development assistance (ODA). Compared to other inflows, remittances remain an important source of foreign currency even as they decline in importance: remittances as a share of total foreign financing fell from 46 percent in 1995 to 18 percent in 2007.

\section{More recent econometric evidence suggests that} remittances are becoming increasingly procyclical, thus reducing their role as a shock absorber. Disaggregated data from Portugal, France, and the USA suggest that remittances are positively associated with business cycles in Cape Verde: a 1 percent increase in real GDP growth in Cape Verde raises remittances by approximately 2.5 percent. Detrended by the Hodrick-Prescott filter, remittances and GDP show a relatively high correlation of 70 percent from 1980 through 2006. Overall, the relationship between remittances and GDP based on a battery of empirical analysis suggest that remittances have been increasingly

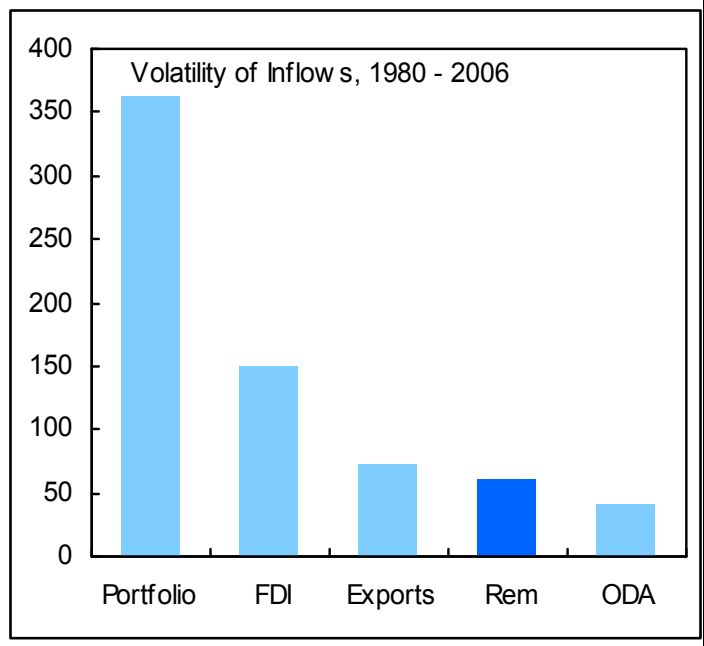
motivated by investment considerations rather than altruistic considerations or for consumption smoothing.

${ }^{1}$ Selected Issues, Chapter 2. 


\section{B. Preserving Financial Stability}

Staff and the authorities agreed on the challenges posed by the continued deceleration of the growth of nonresidents deposits in the banking system. The slowdown poses both liquidity risk for banks and a potential capital account based source of vulnerability.

\section{The mission called for enhanced monitoring} of nonresident deposits in the banking system and more generally the funding base for banks. Banks noted that the slowdown in non-resident deposit flows into the banking system was due to new investment opportunities in the Cape Verde Stock Exchange. Some nonresidents are reportedly diversifying their portfolios away from bank deposits in a search for higher yields in equities. Better monitoring of the sources and direction of these deposits is important for promptly detecting potentially destabilizing capital flows to gauge the appropriateness of the official policy interest rate. The slowdown of these deposits can be better managed on two fronts:

\section{- Continue BCV's cautious approach of} conducting monetary management consistent with the peg. The mission noted that the BCV should continue to carefully set its short-run official policy interest rate consistent with its endogenous equilibrium level - the level that smoothes inflows or outflows of short-term capital. ${ }^{17}$

\section{- $\quad$ Strengthen the banking system. Strong}

oversight of banking system soundness would help attract more diverse sources of financing as a way to grow out of dependence on nonresident deposits. Recent measures taken to strengthen the financial system (LOI I 5) will go toward meeting this goal. The BCV should

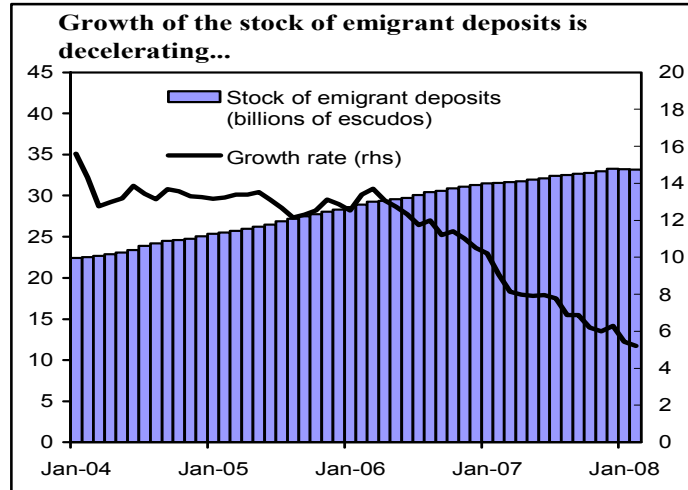

... due in part to narrowing spreads between domestic and Euro deposit rates...

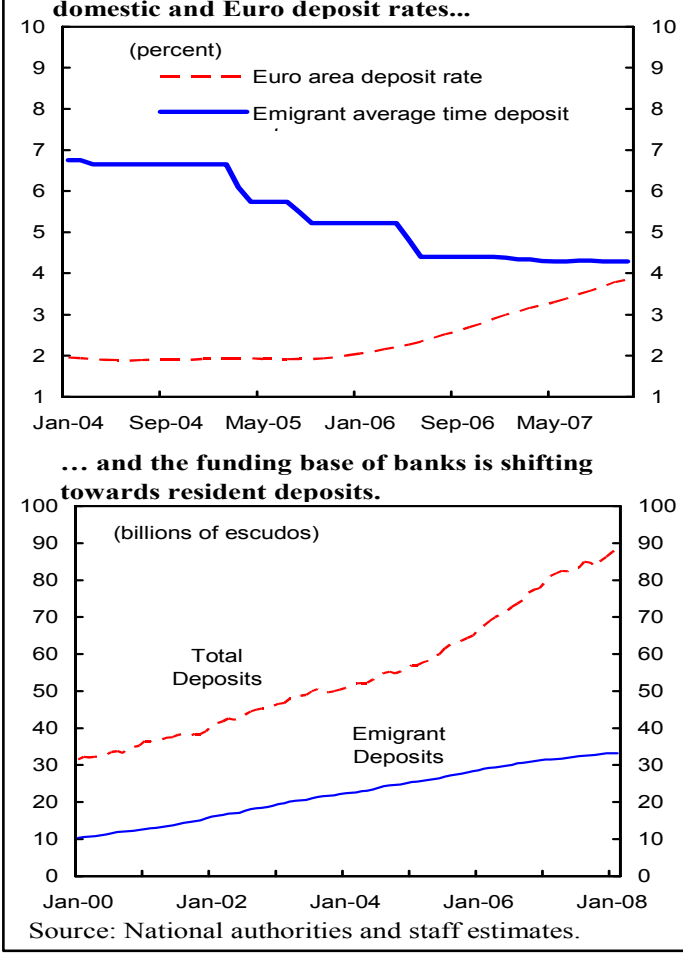

\footnotetext{
${ }^{17}$ Staff's analytic work shows that BCV's policy rate (based on the 14 day BCV paper), is in the long run in line with the exogenous Euro interest rate and the exchange rate peg (the convergence is relatively fast), while in the short term the BCV adjusts its policy rate taking into account the interest differential between the domestic banks' deposit and Euro deposit rates to smooth out foreign flows.
} 
also follow up on the recommendations of the recent MCM technical assistance for an enhanced macro-prudential surveillance framework to be built around an expanded set of financial soundness indicators.

\section{The authorities stated that the financial system is broadly sound and banks have} ample liquid assets. The BCV noted that they view the continued decline in the growth of nonresident deposits from the perspective of a changing balance of payments rather than the impact on bank liquidity, as resident deposits are gradually becoming a dominant source of funding for banks. ${ }^{18}$ To better measure how interest-sensitive non-resident deposits are, the $\mathrm{BCV}$ will closely monitor external flows (including these nonresident flows), an action that will be supported under the PSI as a structural benchmark (LOI, ๆ 11). They also noted that their plans to liberalize financial flows will also support the diversification of the financial system. The authorities noted, and staff concurred, that removing bureaucratic burdens on certain types of financial flows should not pose any near-term risk; it would largely validate the current de facto situation, remove formal restrictions hampering resident participation in tourism projects, and further develop Cape Verde as an international financial center. ${ }^{19}$

\section{The mission recommended strengthening the framework for analyzing the real-}

financial sector linkages. While the current macro-prudential surveillance framework, which is focused mostly on banks, shows a sector that seems to be generally sound, available financial soundness indicators (FSIs) are limited in scope and coverage. ${ }^{20}$

- $\quad$ Cape Verde's FSIs compare well with international benchmarks and are better than the average for sub-Saharan Africa. Banks generally comply with the prudential requirements, thanks to $\mathrm{BCV}$ enforcement efforts. New regulations for both on- and off-shore banks on capital ratios, provisioning and loan classification, credit risk assessment, and credit concentration were published in November 2007.

- $\quad$ However, the lack of a broader macro-prudential surveillance leaves considerable uncertainty about current and emerging macro-critical risks and vulnerabilities. Better understanding the links between the tourism boom and the real estate market, and the financial system is urgent. Anecdotal evidence suggests a significant price rise in the luxury end of the real estate market boosted by non-residents' demand for second homes. Although

\footnotetext{
${ }^{18}$ The evidence on the interest sensitivity of these non-resident deposits is mixed based on extensive econometric analysis by staff; see (WP/06/132 - "Determinants of Emigrants Deposits in Cape Verde"). More recent data analysis did not radically alter that paper's conclusions.

${ }^{19}$ Portfolio investments and forward foreign exchange transactions are liberalized. FDI, external borrowing, and capital transfers abroad are formally subject to BCV authorization.

${ }^{20}$ The capital adequacy ratios of all banks are above 10 percent. The NPL ratio for the four onshore banks, which averaged about 4 percent in 2006, increased in 2007 as stricter loan classification criteria were implemented.
} 
banks exposure to the residential real estate is mainly with residents and largely backed by collateral (with a loan-to-value ratio of 80 percent), some banks are now also venturing into large real estate projects to non-residents without a comprehensive credit risk assessment - at commercial banks themselves, and at the macro-prudential level at the BCV. While nonresidents purchasing second homes are more loyal to sustain tourist arrivals, shocks to tourism could propagate to the real estate market and may affect banks. Furthermore, continued slowdown of non-resident deposits may subject the banking system to liquidity risk. The forthcoming FSAP should help to strengthen the authorities' hands on these issues.

\section{Maintaining Competitiveness and Fostering Private Sector Development}

Both staff and authorities view the exchange rate as broadly in line with macroeconomic fundamentals, and the peg remains appropriate and supported by domestic policies. The authorities agreed with staff on the need for broader export diversification, and increased price flexibility consistent with the peg, and to foster private sector development.

20. The mission called on the authorities to use the window of opportunity provided by the tourism boom to diversify the economy and improve price flexibility to enhance resilience to shocks. Structural reforms to make the economy more flexible will be key to competitiveness and to sustaining high growth in the long term. The authorities' efforts to address both infrastructure gaps and labor market rigidities bode well for enhancing growth, as do Cape Verde's recent accession to the WTO and its commitment to liberalize trade. Sustained productivity growth is essential to maintain competitiveness.

\begin{tabular}{|lrr|}
\hline \multicolumn{3}{|c|}{$\begin{array}{c}\text { Cape Verde: Selected Economic Integration and } \\
\text { Openness Indicators }\end{array}$} \\
\hline & 1998 & 2006 \\
\hline Main merchandise import: EU share & 76.9 & 73.2 \\
Main merchandise export: EU share & 99.3 & 85.8 \\
Tourist arrivals: EU share & $\ldots$ & 87.6 \\
Remittances: EU share & 70.5 & 78.5 \\
\hline source: National authorities & \\
\hline
\end{tabular}

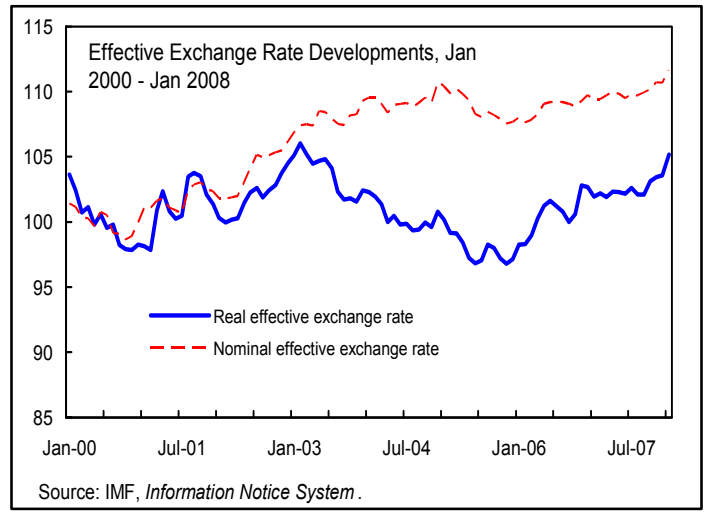

21. Cape Verde's balance of payments position is consistent with external stability and the tourism boom does not raise undue concerns. Staff and the authorities agreed that the recent increase in the current account deficit is no reason for concern because it is largely linked to FDI-related imports, and there is an automatic stabilizer (imports will decelerate if tourism and FDI flows decelerate). Although tourism inflows also affect the determination of the real effective exchange rate (REER), the REER is broadly in line with fundamentals (Box 3). While the rate generally appreciated during 2005-07 reversing the depreciation of 2003-04, the REER has fluctuated around a constant for the last several years in response to 
supply-side-driven inflation differentials. This said, the staff noted the significant appreciation of the euro against the US dollar warrants close monitoring.

\section{With both monetary management and fiscal policy promoting external} stability, staff and the authorities agreed that exchange rate peg has served Cape Verde well as an anchor for financial stability and remains the appropriate regime. The peg has also helped to achieve lower inflation at little apparent cost in terms of lost growth. ${ }^{21}$ The existence of a large dominant trading partner-the European Union-whose business cycles are highly synchronized with Cape Verde, provides an obvious standard of reference for the peg. This said, staff and authorities agreed that there would be no discernible gains from hardening the peg given entrenched fiscal discipline, much enhanced policy credibility, and greater investor confidence. On the contrary, alternatives for hardening the peg would necessarily entail additional fiscal costs and the monetary and reserve management could be complicated during the transition to such arrangements.

Figure 6. Cape Verde Escudo Peg to the Euro Performance
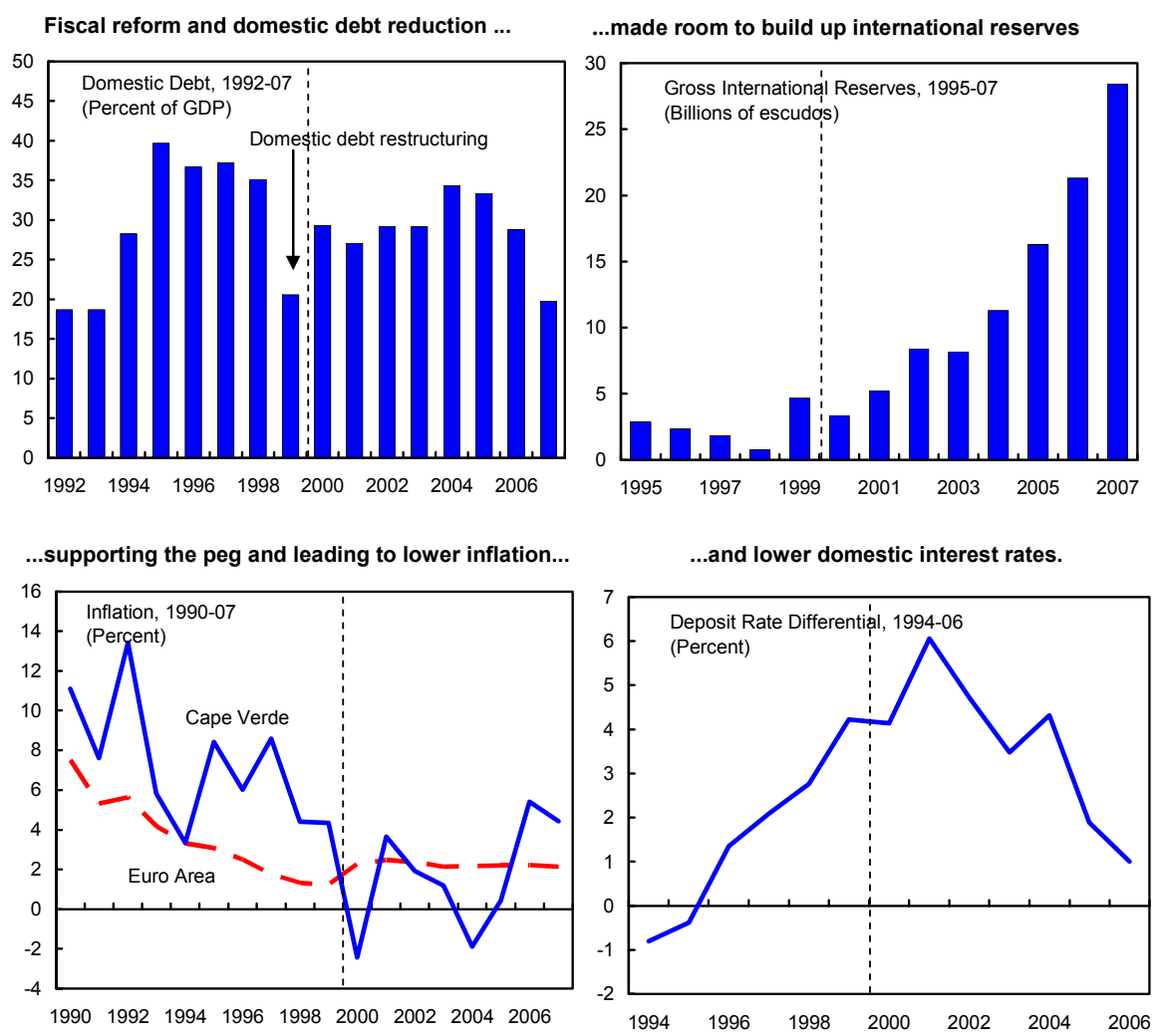

Source: IMF World Economic Outlook, IMF International Financial Statistics, and National authorities.

\footnotetext{
${ }^{21}$ This is consistent with cross-country evidence showing that for developing countries with little exposure to international capital movements, pegged exchange rates work well (Rogoff et al., 2004).
} 


\section{Box 3. Assessment of External Stability}

The current account and fundamental misalignment: Directly estimating Cape Verde's current account norm through the macroeconomic balance approach of the Consultative Group on Exchange Rates is complicated by data limitations and frequent structural breaks resulting from rapid structural changes. The exchange rate will thus be assessed by (i) analyzing the reduced-form relationship between the real effective exchange rate (REER) and certain macroeconomic fundamentals; (ii) assessing the exchange rate regime; and (iii) assessing the sustainability of domestic policies.

- The current and equilibrium REER: Cape Verde's balance of payments is consistent with external stability, and there is no strong evidence of fundamental exchange rate misalignment. The results of the equilibrium real exchange rate approach show that the REER was significantly overvalued from 1992 through 1999, but after adoption of the peg in late 1998 the REER depreciated, and in recent years it has remained close to equilibrium despite large FDI inflows. Other indicators also suggest that Cape Verde's competitiveness is broadly improving (see table). Possible Balassa-Samuelson (BS) effects coming from large tourism inflows are likely to be limited: while the actual REER will rise, given the tourism boom so will the equilibrium REER. In any case, with an unemployment rate of about 20 percent, any B-S effect on the nontradable sector is likely to be moot. In addition, there is no

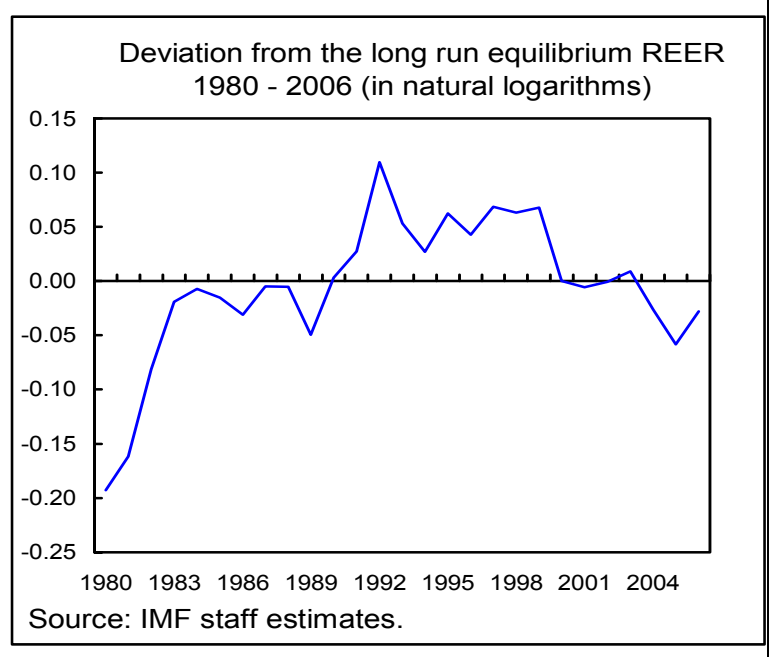
strong wage indexation in Cape Verde. Assessment: The current exchange rate is broadly in line with macroeconomic fundamentals.

- Exchange rate regime: The exchange rate peg is supported by domestic policies, has contributed to external stability, and has not pushed the REER out of line with fundamentals. Overall, the exchange rate regime has served Cape Verde well as an anchor for financial stability (see $\uparrow 22$ and Figure 6). Assessment: The peg has promoted external stability and remains appropriate.

- Domestic policies: These have generally promoted both domestic and external stability (Figure 6). Cape Verde's success in attracting more FDI than neighboring economies despite having no natural resource advantage reflects the strength of its domestic policies and reforms. The fiscal position is solid and sustainable. The recent debt sustainability analysis shows that the risk of debt distress remains low even under alternative stress scenarios (Country Report 08/37).

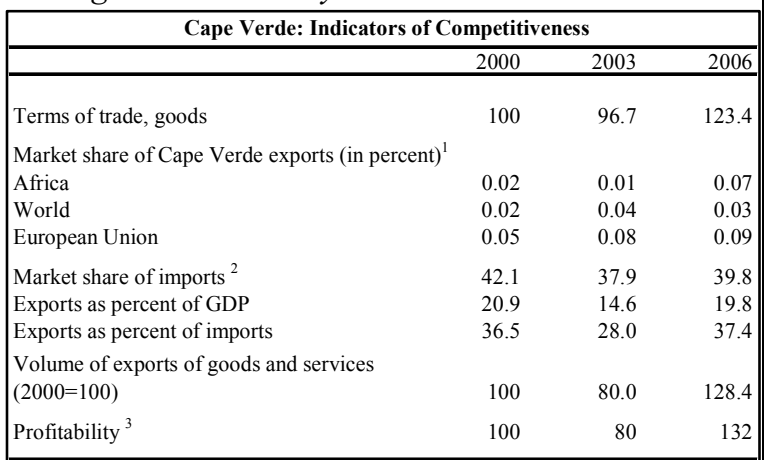

Sources: IMF, Information Notice System, national authorities, and staff estimates. Notes:

Unless noted otherwise, an increase (decrease) in indicators implies a improvement in (deterioration of ) competitiveness.

${ }^{1}$ Ghana exports to selected countries as percent of those countries' total imports. ${ }^{2}$ Imports of goods and services as percent of domestic demand. An increase (decrease) in the indicator implies a deterioration of (improvement in) competitiveness.

${ }^{3}$ Ratio of export price index $(2000=100)$ to tetriary GDP deflator $(2000=100)$ Continued fiscal consolidation has significantly reduced domestic debt and helped to create fiscal space for a modest increase in capital expenditure to ease infrastructure bottlenecks. Monetary management is appropriately adjusting the interest differential with the euro area and has avoided destabilizing short-term capital flows. Assessment: Fiscal and monetary policies are consistent with domestic stability and internal balance.

- The capital and financial accounts and external stability: Private capital flows are related primarily to nondebt creating FDI flows in the tourism sector. Cape Verde remains largely unexposed to movements in international capital markets and cross-border non-emigrant flows. The BCV is closely monitoring vulnerability from the recent slowdown in emigrant deposits. Assessment: The capital and financial account does not pose major concerns for external instability. 
23. The mission urged the authorities to facilitate the diversification of the export base and enhance the economy's resilience to shocks. Actions to improve conditions for the private-sector-led development could be implemented in two areas:

- Promote economic diversification to ensure that growth is sustainable for the

long term: The mission urged the authorities to implement an export diversification strategy that could draw on the conclusions of the Diagnostic Trade Integration Study (DTIS) being conducted through the Integrated Framework agency consortium. ${ }^{22}$

\section{- Improve wage and price}

flexibility: Given the peg, greater

flexibility in both labor market and energy prices is needed to facilitate adjustment to shocks. The mission welcomed the recent opening of the Citizen House, which will strengthen the business environment by, for instance, reducing the time to start a business from 52 days to 1 (something not yet reflected in the 2008 investment climate indicators); facilitate entrepreneurship; and ensure sustainable growth. However, staff emphasized that the authorities should address other issues related to the cost of doing business.

While Cape Verde ranks above average on some indicators, it fares poorly on such labor market indicators as cost of hiring and firing.

\begin{tabular}{|c|c|c|c|}
\hline \multicolumn{4}{|c|}{ Selected Investment Climate Indicators, 2008} \\
\hline & $\begin{array}{l}\text { Cape Verde } \\
\text { compared to } \\
\text { other tourist } \\
\text { economies }\end{array}$ & Cape Verde & $\begin{array}{l}\text { Small island } \\
\text { tourist } \\
\text { economies }{ }^{1}\end{array}$ \\
\hline Rank on ease of doing business ${ }^{2}$ & Worse & 132 & 61 \\
\hline $\begin{array}{l}\text { Starting a business } \\
\text { (Number of days) }\end{array}$ & Worse & 52 & 29 \\
\hline $\begin{array}{l}\text { Cost of starting a business } \\
\text { (\% of GNI per capita) }\end{array}$ & Worse & 40 & 22 \\
\hline $\begin{array}{l}\text { Rigidity of employment } \\
(\text { Index }=0-100)\end{array}$ & Worse & 44 & 15 \\
\hline $\begin{array}{l}\text { Firing cost of employees } \\
\text { (weeks of salary) }\end{array}$ & Worse & 91 & 40 \\
\hline $\begin{array}{l}\text { Strength of investor protection } \\
\text { (Index }=0-10)\end{array}$ & Worse & 4 & 6 \\
\hline $\begin{array}{l}\text { Time to register property } \\
\text { (Number of days) }\end{array}$ & About same & 83 & 80 \\
\hline $\begin{array}{r}\text { Enforcing contracts } \\
\text { (Number of days) }\end{array}$ & Better & 465 & 593 \\
\hline $\begin{array}{l}\text { Cost enforcing contracts } \\
\text { ( } \% \text { of claim) }\end{array}$ & Better & 24 & 37 \\
\hline $\begin{array}{l}\text { Source: World Bank, Doing Busine } \\
{ }^{1} \text { Average of St. Luica, Antigua an } \\
\text { St. Vincent and Grenadines, Vanue } \\
\text { Grenada, Dominican Republic, Tor } \\
{ }^{2} \text { A smaller index means an impro }\end{array}$ & $\begin{array}{l}\text { oort (2008). } \\
\text { uda, Malvides, } \\
\text { minica, Samoa, } \\
\text { inidad and Toba } \\
\text { t in the rank. }\end{array}$ & $\begin{array}{l}\text { elles, St. Kitts a } \\
\text { ica, Fiji, Mauritic } \\
\text { nd Paua New C }\end{array}$ & evis, \\
\hline
\end{tabular}

\section{The authorities noted that they are moving ahead with their strategy for diversifying exports and making prices more flexible:}

- They are developing several sectors: offshore financial center, which will be enhanced by the new prudential regulation and the new AML/CFT law; the fishing and fishprocessing industry, marine and transshipment services; and information technology (IT) which has already begun with a recent agreement between NOSi and Microsoft to facilitate government e-commerce and data processing across Cape Verde. They also pointed out that even within tourism there is room for diversification.

\footnotetext{
${ }^{22}$ The DTIS will examine, among other issues, how Cape Verde can enter into the enormous and expanding offshore services, information technology, and business process outsourcing market.
} 
- $\quad$ The authorities recognize the need to make the labor market more flexible and agreed that the recent new labor code will not do much to accomplish that. They plan to upgrade human capital, retrain labor, attract skilled workers, and improve the mechanism for addressing arbitration and labor disputes. With recent steps taken on energy pricing, a rapid pass-through of energy prices will facilitate faster adjustment to terms of trade swings.

\section{Statistics Issues}

25. The macroeconomic data are broadly adequate for surveillance and program monitoring. The mission welcomed recent improvements in data release. INE recently released a new CPI index and a new web portal, both of which go toward strengthening data collection and improving disclosure. The authorities also now publish most of their data on the Internet. ${ }^{23}$ In line with STA's recommendation, the mission stressed the increased importance of unambiguously indicating data links in the official websites and regularly updating the metadata for General Data Dissemination Standards (GDDS).

\section{However, capacity constraints are severe, and further improvements in data are} needed. Specifically:

- GDP/national accounts: The lack of reliable demand-side GDP data constrains policy formulation, although the BCV does project demand-side GDP.

- Labor market statistics: Data on unemployment are compiled with long delays, and wage data are nonexistent.

- $\quad$ Tourism statistics: Better data on tourism arrivals and prices would allow the authorities to gauge the economy's competitiveness, given the specialization in tourism. INE noted that it plans to compile Tourism Satellite Account statistics.

- $\quad$ Fiscal data: The new chart of public accounts (PNCP) will not be ready until 2009.

\section{Staff ApPraisal}

27. Cape Verde's impressive economic performance in recent years is a tribute to its sound homegrown economic reform program. The authorities are to be commended for their prudent macroeconomic management. Good policies have catalyzed investments and export growth, especially in tourism, breaking past dependence on aid and remittances. Economic growth is strong, inflation is moderate, and the unemployment and poverty rates have been gradually falling.

\section{Staff view the exchange rate as broadly in line with macroeconomic} fundamentals, and the peg remains appropriate. Fiscal policy and monetary management

\footnotetext{
${ }^{23}$ Ministry of Finance: www.minfin.cv; Central Bank: www.bcv.cv; and Statistics Institute: www.ine.cv.
} 
are promoting external stability. The peg has served Cape Verde well and helped to achieve low inflation. Staff sees no discernible gains from hardening the peg given entrenched fiscal discipline, much enhanced policy credibility, and greater investor confidence.

\section{Sustaining this strong performance requires tackling three challenges. First,}

building tourism will require investments in transportation and energy. The challenge will be to use the fiscal space to increase capital expenditures while keeping debt sustainable.

Second, the financial sector still relies on nonresident deposits, and their decelerating growth rate should be monitored as it is a potential capital account-based source of vulnerability. Moreover, Cape Verde's export base is narrow with increasing specialization in tourism. The challenge here is to limit the vulnerability associated with this specialization, diversify sources of growth, and increase the economy's flexibility to enhance resilience to shocks.

30. Continuing prudence in fiscal policy is essential. This is needed to buy policy insurance against shocks and support the peg. A medium-term fiscal strategy is needed to anchor the authorities' expenditure and tax reform plans. Given the larger-than-expected domestic debt reduction in 2007, even with current plans to increase capital spending to ease infrastructure bottlenecks, the risk of debt distress remains low and the envisaged reserve buildup is preserved. These plans would also need to be implemented within the medium term fiscal framework (MTFF) and take into account implementation capacity. Staff urges the authorities to move ahead with their plans toward publishing the MTFF as part of the 2009 budget cycle. The authorities should also pursue their plans to enhance the capacity of their debt management office including through seeking technical assistance.

\section{Strengthening the financial system further is important. Staff welcomes the} recently published regulation that broadly aligned prudential requirements for both on- and offshore banks, which should help preserve Cape Verde's good reputation. Nonetheless, there is a need to broaden the source of funds for banks so they will continue to grow out of dependence on non-resident deposits. Staff recommends improving the monitoring of these nonresident deposits to gauge better the appropriateness of BCV's policy interest rate by promptly detecting potentially destabilizing capital flows. Banks exposure to the real estate market also warrants close monitoring. Staff welcomes the BCV plans to establish an enhanced financial sector macro-prudential surveillance; this will provide a good basis for comprehensive assessment of credit risk. The forthcoming FSAP should help to strengthen the authorities' hands on these issues, including on the real-financial sector linkages.

\section{Structural reforms are necessary to maintain external competitiveness and} sustain high growth over the long term. Staff calls on the authorities to implement their strategy for export diversification. Given the peg, greater flexibility in labor markets and energy prices is also needed to facilitate adjustment to shocks. To remove labor market rigidities, the authorities should address the high cost of hiring and firing. The authorities' plans to upgrade human capital, retrain labor, and attract skilled workers are important. On energy prices, regular application of the new utilities base tariffs and fuel pricing formula is 
essential for fast adjustment to terms of trade changes. Staff urges the authorities to accelerate the implementation of their broader energy sector reforms to further reduce fiscal risk and unleash Cape Verde's growth and poverty reduction potential.

33. Staff recommends completion of the fourth review of the PSI program. Based on the strength of the authorities' policies and the corrective measures taken, the staff supports granting a waiver for the missed structural assessment criterion.

34. The next Article IV Consultation will be held in accordance with the decision on consultation cycles approved on July 15, 2002. 
Table 1. Cape Verde: Selected Indicators, 2006-13

\begin{tabular}{|c|c|c|c|c|c|c|c|c|}
\hline & 2006 & 2007 & $2008^{1}$ & 2009 & 2010 & 2011 & 2012 & 2013 \\
\hline & & Est. & \multicolumn{6}{|c|}{ Proj } \\
\hline & \multicolumn{8}{|c|}{ (Annual percentage change) } \\
\hline \multicolumn{9}{|l|}{ National accounts and prices } \\
\hline Real GDP & 10.8 & 6.9 & 6.5 & 6.5 & 7.0 & 7.1 & 6.8 & 6.7 \\
\hline Real GDP per capita & 8.8 & 5.0 & 4.5 & 4.5 & 5.0 & 5.1 & 4.8 & 4.6 \\
\hline Consumer price index (annual average) & 5.4 & 4.4 & 3.6 & 2.3 & 2.3 & 2.3 & 2.3 & 2.3 \\
\hline Consumer price index (end of period) & 6.2 & 3.8 & 2.6 & 2.3 & 2.3 & 2.3 & 2.3 & 2.3 \\
\hline \multicolumn{9}{|l|}{ External sector } \\
\hline Exports of goods and services & 35.0 & 14.1 & 20.9 & 16.5 & 13.9 & 14.5 & 13.3 & 14.1 \\
\hline Of which: tourism & 82.5 & 40.6 & 31.6 & 23.8 & 17.7 & 17.0 & 15.1 & 15.4 \\
\hline Imports of goods and services & 23.4 & 17.9 & 13.9 & 13.2 & 13.6 & 8.2 & 15.3 & 13.8 \\
\hline Real effective exchange rate (annual average) & 2.7 & 1.3 & $\ldots$ & $\ldots$ & $\ldots$ & $\ldots$ & $\ldots$ & $\ldots$ \\
\hline Terms of trade (minus $=$ deterioration) & -4.4 & -0.9 & -4.4 & 0.9 & 1.2 & 1.1 & 1.1 & 1.1 \\
\hline \multicolumn{9}{|l|}{ Government finance } \\
\hline Total revenue (excluding grants) & 19.6 & 17.0 & 5.8 & 13.2 & 13.0 & 9.8 & 14.7 & 14.3 \\
\hline Total expenditure & 11.8 & -0.7 & 22.4 & 12.4 & 14.7 & 3.2 & 12.7 & 12.0 \\
\hline Noncapital expenditure & 11.6 & -0.4 & 11.4 & 12.4 & 14.4 & 9.0 & 14.1 & 16.0 \\
\hline Capital expenditure & 12.1 & -1.4 & 43.7 & 12.4 & 15.1 & $-5.3^{6}$ & 10.3 & 4.9 \\
\hline \multicolumn{9}{|l|}{ Money and credit } \\
\hline Net foreign assets & 14.8 & 22.9 & 20.3 & 16.8 & 11.7 & 17.2 & 15.8 & 14.5 \\
\hline Net domestic assets & 19.0 & 5.5 & 7.6 & 10.2 & 14.0 & 7.3 & 13.9 & 14.4 \\
\hline Of which: net claims on the central government & 1.2 & -42.3 & -2.1 & -13.9 & -12.5 & -27.1 & 12.7 & 23.2 \\
\hline credit to the economy ${ }^{2}$ & 17.3 & 28.0 & 14.6 & 14.6 & 17.6 & 10.7 & 14.3 & 14.2 \\
\hline Broad money (M2) & 17.7 & 10.6 & 11.8 & 12.5 & 13.2 & 10.9 & 14.6 & 14.4 \\
\hline Domestic broad money (M2X) & 22.4 & 13.1 & 15.2 & 15.9 & 16.5 & 14.0 & 17.7 & 14.4 \\
\hline Income velocity (GDP/M2) ${ }^{3}$ & 1.34 & 1.29 & 1.29 & 1.29 & 1.29 & 1.27 & 1.28 & 1.28 \\
\hline \multirow[t]{2}{*}{ Reserve money (M0) } & 3.4 & 9.7 & 12.8 & 12.3 & 13.0 & 10.9 & 14.7 & 14.6 \\
\hline & \multicolumn{8}{|c|}{ (Percent of GDP) } \\
\hline \multicolumn{9}{|l|}{ Saving-investment balance } \\
\hline Gross capital formation & 43.0 & 42.6 & 45.0 & 46.9 & 48.7 & 47.2 & 47.6 & 46.1 \\
\hline Government & 6.1 & 5.1 & 6.5 & 7.0 & 7.6 & 8.3 & 8.2 & 7.9 \\
\hline Nongovernment & 36.9 & 37.4 & 38.4 & 39.9 & 41.1 & 38.8 & 39.4 & 38.2 \\
\hline Gross national savings & 38.0 & 33.4 & 35.6 & 37.0 & 38.2 & 38.9 & 37.6 & 35.5 \\
\hline Of which: government & 9.3 & 9.9 & 7.4 & 7.0 & 6.7 & 5.9 & 6.1 & 6.2 \\
\hline External current account (including official current transfers) & -5.0 & -9.1 & -9.4 & -9.9 & -10.5 & -8.3 & -10.0 & -10.6 \\
\hline \multicolumn{9}{|l|}{ Government finance } \\
\hline Total domestic revenue & 23.9 & 25.4 & 24.2 & 24.4 & 24.5 & 24.4 & 24.5 & 24.6 \\
\hline Total external grants & 5.5 & 4.8 & 5.6 & 4.7 & 4.7 & 2.9 & 2.8 & 2.7 \\
\hline Total expenditure & 34.3 & 30.9 & 34.0 & 34.2 & 34.8 & 32.5 & 32.1 & 31.6 \\
\hline Overall balance before grants & -10.4 & -5.5 & -9.9 & -9.7 & -10.3 & -8.1 & -7.6 & -7.0 \\
\hline Overall balance (including grants) & -4.9 & -0.7 & -4.2 & -5.0 & -5.5 & -5.3 & -4.9 & -4.4 \\
\hline External financing (net) & 3.0 & 2.0 & 2.4 & 2.9 & 3.0 & 2.8 & 2.8 & 2.5 \\
\hline Domestic financing (net) & 2.9 & -0.8 & 1.8 & 2.0 & 2.6 & 2.4 & 2.1 & 1.9 \\
\hline Financing gap/ statistical discrepancy & -0.9 & -0.5 & 0.0 & 0.0 & 0.0 & 0.0 & 0.0 & 0.0 \\
\hline Total nominal government debt ${ }^{4}$ & 76.0 & 66.9 & 60.9 & 57.4 & 55.2 & 54.2 & 51.6 & 48.9 \\
\hline External government debt ${ }^{5}$ & 47.2 & 47.2 & 44.5 & 42.4 & 40.2 & 38.9 & 36.7 & 34.3 \\
\hline Domestic government debt, net of deposits & 28.8 & 19.7 & 16.4 & 15.0 & 14.9 & 15.3 & 14.9 & 14.6 \\
\hline External current account (excluding official current transfers) & -9.1 & -13.5 & -12.4 & -11.8 & -12.2 & -9.6 & -11.3 & -11.7 \\
\hline Overall balance of payments & 4.7 & 6.1 & 4.2 & 4.2 & 3.0 & 4.5 & 4.3 & 4.0 \\
\hline External current account ( $€$ millions, including official transfers) & -47.7 & -96.4 & -110.2 & -130.0 & -155.1 & -135.0 & -187.0 & -224.2 \\
\hline Gross international reserves (€ millions, end of period) & 193.1 & 257.7 & 307.3 & 363.0 & 407.6 & 481.6 & 561.4 & 646.9 \\
\hline Gross international reserves to reserve money & 1.0 & 1.2 & 1.3 & 1.4 & 1.4 & 1.4 & 1.4 & 1.4 \\
\hline $\begin{array}{l}\text { Gross international reserves (months of prospective imports of } g \\
\text { and services) }\end{array}$ & 3.1 & 3.6 & 3.8 & 3.9 & 4.1 & 4.2 & 4.3 & 4.4 \\
\hline External debt service (percent of exports of goods and services) & 5.7 & 4.7 & 4.1 & 3.7 & 3.7 & 3.9 & 4.0 & 4.7 \\
\hline \multicolumn{9}{|l|}{ Memorandum items: } \\
\hline Nominal GDP (billions of Cape Verde escudos) & 105.6 & 116.3 & 129.4 & 144.9 & 163.2 & 180.2 & 205.6 & 234.2 \\
\hline \multicolumn{9}{|l|}{ Exchange rate (Cape Verde escudos per US\$) } \\
\hline Period average & 87.8 & 80.4 & $\ldots$ & $\ldots$ & $\ldots$ & $\ldots$ & $\ldots$ & $\ldots$ \\
\hline End period & 83.5 & 75.6 & $\cdots$ & $\cdots$ & $\cdots$ & $\cdots$ & $\cdots$ & $\cdots$ \\
\hline
\end{tabular}

Sources: Cape Verdean authorities, and IMF staff estimates and projections.

${ }^{1}$ For 2008, the government finance indicators refer to budget figures.

${ }^{2}$ Excluding a December 2006 purchase of a Portuguese credit to Electra and subsequent offloading on the domestic securities market.

${ }^{3}$ Velocity is nominal GDP devided by average end period broad money. Velocity declines gradually because of financial deepening.

${ }^{4}$ Net of central government deposits; including verified stock of domestic and external arrears.

${ }^{5}$ Excluding claims on the offshore Trust Fund.

${ }^{6}$ Capital expenditures decelerate in 2011 as the execution of the MCC grant is completed. 
Table 2. Cape Verde: Fiscal Operations of the Central Government, 2006-10 (Millions of Cape Verde escudos, unless otherwise indicated)

\begin{tabular}{|c|c|c|c|c|c|c|c|}
\hline & \multicolumn{2}{|c|}{2006} & \multicolumn{2}{|c|}{2007} & \multirow{2}{*}{$\frac{2008}{\text { Budget }}$} & 2009 & 2010 \\
\hline & Program & Actual & Budget & Prel. & & \multicolumn{2}{|c|}{ Proj. } \\
\hline Revenue, grants, and net lending & 33,437 & 31,044 & 35,295 & 35,131 & 38,551 & 42,285 & 47,759 \\
\hline Domestic revenue (incl. net lending) & 24,604 & 25,255 & 26,963 & 29,559 & 31,286 & 35,417 & 40,030 \\
\hline Tax revenue & 21,099 & 22,828 & 24,178 & 26,423 & 28,059 & 31,859 & 36,015 \\
\hline Income and profit taxes & 6,955 & 6,952 & 7,497 & 7,656 & 8,462 & 9,584 & 10,915 \\
\hline Consumption taxes & 8,351 & 9,821 & 10,140 & 11,565 & 13,177 & 14,829 & 16,812 \\
\hline International trade taxes & 4,501 & 4,889 & 5,458 & 5,592 & 5,583 & 6,509 & 7,232 \\
\hline Other taxes & 1,291 & 1,166 & 1,083 & 1,611 & 837 & 937 & 1,056 \\
\hline Nontax revenue & 3,505 & 2,126 & 2,585 & 2,843 & 3,204 & 3,558 & 4,015 \\
\hline Net lending & 0 & 301 & 200 & 293 & 23 & 0 & 0 \\
\hline External grants & 8,833 & 5,789 & 8,332 & 5,572 & 7,265 & 6,868 & 7,730 \\
\hline Capital grants & 7,003 & 4,035 & 6,706 & 4,009 & 5,597 & 6,133 & 6,930 \\
\hline Budget support & 1,830 & 1,755 & 1,625 & 1,563 & 1,668 & 736 & 800 \\
\hline Total expenditure & 40,413 & 36,252 & 39,943 & 35,986 & 44,032 & 49,504 & 56,778 \\
\hline Recurrent expenditure & 22,416 & 18,887 & 22,564 & 22,308 & 24,950 & 27,398 & 31,043 \\
\hline Primary recurrent expenditure & 20,593 & 16,967 & 20,681 & 20,428 & 22,896 & 25,156 & 28,533 \\
\hline Wages and salaries & 12,712 & 11,547 & 13,165 & 12,491 & 14,245 & 15,892 & 18,094 \\
\hline Goods and services & 1,862 & 1,197 & 2,127 & 1,853 & 2,335 & 2,615 & 2,947 \\
\hline Transfers and subsidies & 5,146 & 3,464 & 3,869 & 5,219 & 4,453 & 4,563 & 5,141 \\
\hline Transfers & 3,921 & 3,172 & 3,834 & 3,309 & 4,395 & 4,498 & 5,068 \\
\hline Subsidies & 1,225 & 292 & 35 & 1,910 & 58 & 65 & 73 \\
\hline Of which: energy subsidies & 1,200 & 208 & 0 & $1,802^{1}$ & 0 & 0 & 0 \\
\hline Other expenditures & 873 & 760 & 1,520 & 864 & 1,863 & 2,086 & 2,351 \\
\hline Domestic interest payments & 1,300 & 1,398 & 1,352 & 1,361 & 1,487 & 1,578 & 1,689 \\
\hline External interest payments & 522 & 522 & 531 & 519 & 566 & 664 & 822 \\
\hline Extraordinary expenditures & 0 & 0 & 0 & 0 & 0 & 0 & 0 \\
\hline Capital expenditure & 16,290 & 12,415 & 16,340 & 12,237 & $17,581^{2}$ & 19,769 & 22,754 \\
\hline Foreign financed & 12,534 & 11,173 & 13,487 & 9,599 & 12,470 & 13,097 & 14,748 \\
\hline Domestically financed & 3,755 & 1,242 & 2,853 & 2,638 & 5,111 & 6,672 & 8,006 \\
\hline Other expenditures (incl. arrears clearance) & 1,708 & 4,950 & 1,039 & 1,440 & 1,500 & 2,337 & 2,981 \\
\hline Of which: energy subsidies & 0 & 204 & 0 & 0 & 0 & 0 & 0 \\
\hline Overall balance, including grants (budget basis) & $-6,976$ & $-5,208$ & $-4,648$ & -855 & $-5,481$ & $-7,219$ & $-9,018$ \\
\hline Financing & 6,976 & 5,208 & 4,648 & 855 & 5,481 & 7,219 & 9,018 \\
\hline Foreign, net & 3,414 & 3,130 & 3,043 & 2,326 & 3,160 & 4,249 & 4,829 \\
\hline Domestic, net & 3,575 & 3,027 & 1,605 & -889 & 2,321 & 2,970 & 4,189 \\
\hline Net domestic borrowing & 830 & 1,638 & -602 & $-2,567$ & -172 & 1,470 & 2,689 \\
\hline Banking system & 989 & 185 & $\ldots$ & $-6,509$ & 248 & $\ldots$ & $\ldots$ \\
\hline Nonbanks & -158 & 1,453 & $\ldots$ & $3,941^{6}$ & -421 & $\ldots$ & $\ldots$ \\
\hline Privatization and other sales of assets & 3,689 & 456 & 2,207 & 3,598 & 2,493 & 1,500 & 1,500 \\
\hline Accounts payable (atrasados), net & -944 & 933 & $\ldots$ & $-1,919$ & $\ldots$ & 0 & 0 \\
\hline Net errors and omissions & 0 & -949 & 0 & -582 & 0 & 0 & 0 \\
\hline Financing gap & -13 & 0 & 0 & 0 & 0 & 0 & 0 \\
\hline \multicolumn{8}{|l|}{ Memorandum items: } \\
\hline $\begin{array}{l}\text { Overall balance, including grants (excluding } \\
\text { clearance of arrears and accounts payable) }\end{array}$ & $-4,324$ & $-4,129$ & $-3,609$ & 2,321 & $-3,980$ & $-6,197$ & $-9,018$ \\
\hline $\begin{array}{l}\text { Arrears clearance } \\
\text { Net domestic borrowing, excluding clearance }\end{array}$ & 1,708 & 2,012 & 1,039 & 1,257 & 1,500 & 1,022 & 0 \\
\hline of arrears and net accounts payable & $-1,821$ & 559 & $-1,641$ & $-5,743$ & $-1,673$ & 448 & 2,689 \\
\hline Primary balance (including grants) ${ }^{3}$ & $-5,154$ & $-3,288$ & $-2,765$ & 1,025 & $-3,427$ & $-4,976$ & $-6,508$ \\
\hline Recurrent domestic balance ${ }^{4}$ & 2,188 & 6,368 & 4,400 & 7,250 & 6,335 & 8,018 & 8,987 \\
\hline Net external flows ${ }^{5}$ & 12,234 & 8,919 & 11,375 & 7,898 & 10,425 & 11,117 & 12,559 \\
\hline $\begin{array}{l}\text { External debt service (percent of } \\
\text { domestic revenue) }\end{array}$ & 10.7 & 9.9 & 9.8 & 7.9 & 8.3 & 7.5 & 7.5 \\
\hline $\begin{array}{l}\text { Domestic debt (including arrears and accounts } \\
\text { payable, net of deposits) }\end{array}$ & 27,902 & 30,405 & 25,426 & 22,925 & 21,253 & 21,701 & 24,390 \\
\hline
\end{tabular}

Sources: Ministry of Finance and Public Administration, Bank of Cape Verde, and IMF staff estimates and projections.

${ }^{1}$ The energy subsidies recorded in 2007 were incurred in previous periods.

${ }^{2}$ The capital expenditure budget is typically underexecuted.

${ }^{3}$ Overall balance (including grants) - total expenditure + domestic and external interest payments.

${ }^{4}$ Domestic revenue - recurrent expenditure.

${ }^{5}$ External grants + net foreign financing.

${ }^{6}$ Reflects borrowing from the pension fund and scheduling of payments to energy companies. 
Table 3. Cape Verde: Fiscal Operations of the Central Government, 2006-10

(Percent of GDP)

\begin{tabular}{|c|c|c|c|c|c|c|c|}
\hline & \multicolumn{2}{|c|}{2006} & \multicolumn{2}{|c|}{2007} & \multirow{2}{*}{$\frac{2008}{\text { Budget }}$} & 2009 & 2010 \\
\hline & Program & Actual & Budget & Prel. & & \multicolumn{2}{|c|}{ Proj. } \\
\hline Revenue, grants, and net lending & 34.1 & 29.4 & 30.4 & 30.2 & 29.8 & 29.2 & 29.3 \\
\hline Domestic revenue (incl. net lending) & 25.1 & 23.9 & 23.2 & 25.4 & 24.2 & 24.4 & 24.5 \\
\hline Tax revenue & 21.5 & 21.6 & 20.8 & 22.7 & 21.7 & 22.0 & 22.1 \\
\hline Income and profit taxes & 7.1 & 6.6 & 6.4 & 6.6 & 6.5 & 6.6 & 6.7 \\
\hline Consumption taxes & 8.5 & 9.3 & 8.7 & 9.9 & 10.2 & 10.2 & 10.3 \\
\hline International trade taxes & 4.6 & 4.6 & 4.7 & 4.8 & 4.3 & 4.5 & 4.4 \\
\hline Other taxes & 1.3 & 1.1 & 0.9 & 1.4 & 0.6 & 0.6 & 0.6 \\
\hline Nontax revenue & 3.6 & 2.0 & 2.2 & 2.4 & 2.5 & 2.5 & 2.5 \\
\hline Net lending & 0.0 & 0.3 & 0.2 & 0.3 & 0.0 & 0.0 & 0.0 \\
\hline External grants & 9.0 & 5.5 & 7.2 & 4.8 & 5.6 & 4.7 & 4.7 \\
\hline Capital grants & 7.1 & 3.8 & 5.8 & 3.4 & 4.3 & 4.2 & 4.2 \\
\hline Budget support & 1.9 & 1.7 & 1.4 & 1.3 & 1.3 & 0.5 & 0.5 \\
\hline Total expenditure & 41.2 & 34.3 & 34.4 & 30.9 & 34.0 & 34.2 & 34.8 \\
\hline Recurrent expenditure & 22.8 & 17.9 & 19.4 & 19.2 & 19.3 & 18.9 & 19.0 \\
\hline Primary recurrent expenditure & 21.0 & 16.1 & 17.8 & 17.6 & 17.7 & 17.4 & 17.5 \\
\hline Wages and salaries & 13.0 & 10.9 & 11.3 & 10.7 & 11.0 & 11.0 & 11.1 \\
\hline Goods and services & 1.9 & 1.1 & 1.8 & 1.6 & 1.8 & 1.8 & 1.8 \\
\hline Transfers and subsidies & 5.2 & 3.3 & 3.3 & 4.5 & 3.4 & 3.1 & 3.1 \\
\hline Transfers & 4.0 & 3.0 & 3.3 & 2.8 & 3.4 & 3.1 & 3.1 \\
\hline Subsidies & 1.2 & 0.3 & 0.0 & 1.6 & 0.0 & 0.0 & 0.0 \\
\hline Of which: energy subsidies & 1.2 & 0.2 & 0.0 & $1.5^{1}$ & 0.0 & 0.0 & 0.0 \\
\hline Other expenditures & 0.9 & 0.7 & 1.3 & 0.7 & 1.4 & 1.4 & 1.4 \\
\hline Domestic interest payments & 1.3 & 1.3 & 1.2 & 1.2 & 1.1 & 1.1 & 1.0 \\
\hline External interest payments & 0.5 & 0.5 & 0.5 & 0.4 & 0.4 & 0.5 & 0.5 \\
\hline Extraordinary expenditures & 0.0 & 0.0 & 0.0 & 0.0 & 0.0 & 0.0 & 0.0 \\
\hline Capital expenditure & 16.6 & 11.8 & 14.1 & 10.5 & $13.6^{2}$ & 13.6 & 13.9 \\
\hline Foreign financed & 12.8 & 10.6 & 11.6 & 8.3 & 9.6 & 9.0 & 9.0 \\
\hline Domestically financed & 3.8 & 1.2 & 2.5 & 2.3 & 4.0 & 4.6 & 4.9 \\
\hline Other expenditures (incl. arrears clearance) & 1.7 & 4.7 & 0.9 & 1.2 & 1.2 & 1.6 & 1.8 \\
\hline Of which: energy subsidies & 0.0 & 0.2 & 0.0 & 0.0 & 0.0 & 0.0 & 0.0 \\
\hline Overall balance, including grants (budget basis) & -7.1 & -4.9 & -4.0 & -0.7 & -4.2 & -5.0 & -5.5 \\
\hline Financing & 7.1 & 4.9 & 4.0 & 0.7 & 4.2 & 5.0 & 5.5 \\
\hline Foreign, net & 3.5 & 3.0 & 2.6 & 2.0 & 2.4 & 2.9 & 3.0 \\
\hline Total drawings & 5.6 & 4.8 & 4.4 & 3.6 & 4.0 & 4.3 & 4.3 \\
\hline Amortization & -2.2 & -1.9 & -1.8 & -1.6 & -1.6 & -1.4 & -1.3 \\
\hline Domestic, net & 3.6 & 2.9 & 1.4 & -0.8 & 1.8 & 2.0 & 2.6 \\
\hline Net domestic borrowing & 0.8 & 1.6 & -0.5 & -2.2 & -0.1 & 1.0 & 1.6 \\
\hline Banking system & $\ldots$ & $\ldots$ & $\ldots$ & -5.6 & 0.2 & $\ldots$ & $\ldots$ \\
\hline Nonbanks & $\ldots$ & $\ldots$ & $\ldots$ & $3.4^{6}$ & -0.3 & $\ldots$ & $\ldots$ \\
\hline Privatization and other sales of assets & 1.4 & 0.4 & 1.9 & 3.1 & 1.9 & 1.0 & 0.9 \\
\hline Accounts payable (atrasados), net & 2.3 & $\ldots$ & $\ldots$ & -1.7 & $\ldots$ & 0.0 & 0.0 \\
\hline Net errors and omissions & 0.0 & -0.9 & 0.0 & -0.5 & 0.0 & 0.0 & 0.0 \\
\hline Financing gap & 0.0 & 0.0 & 0.0 & 0.0 & 0.0 & 0.0 & 0.0 \\
\hline \multicolumn{8}{|l|}{ Memorandum items: } \\
\hline $\begin{array}{l}\text { Overall balance, including grants (excluding } \\
\text { clearance of arrears and accounts payable) }\end{array}$ & & & & & & & -55 \\
\hline $\begin{array}{l}\text { clearance or arrears and accounts payable) } \\
\text { Arrears clearance }\end{array}$ & $\begin{array}{r}-4.4 \\
1.7\end{array}$ & $\begin{array}{r}-3.9 \\
1.9\end{array}$ & $\begin{array}{r}-3.1 \\
0.9\end{array}$ & $\begin{array}{l}2.0 \\
1.1\end{array}$ & $\begin{array}{r}-3.1 \\
1.2\end{array}$ & $\begin{array}{r}-4.3 \\
0.7\end{array}$ & $\begin{array}{r}-5.5 \\
0.0\end{array}$ \\
\hline Net domestic borrowing, excluding clearance of & 1.1 & & & & & & \\
\hline arrears and net accounts payable & -1.9 & 0.5 & -1.4 & -4.9 & -1.3 & 0.3 & 1.6 \\
\hline Primary balance (including grants) ${ }^{3}$ & -5.3 & -3.1 & -2.4 & 0.9 & -2.6 & -3.4 & -4.0 \\
\hline Recurrent domestic balance ${ }^{4}$ & 2.2 & 6.0 & 3.8 & 6.2 & 4.9 & 5.5 & 5.5 \\
\hline Net external flows ${ }^{5}$ & 12.5 & 8.4 & 9.8 & 6.8 & 8.1 & 7.7 & 7.7 \\
\hline Domestic debt (including arrears and accounts & & & & & & & \\
\hline payable, net of deposits) & 28.4 & 28.8 & 21.9 & 19.7 & 16.4 & 15.0 & 14.9 \\
\hline Nominal GDP (Millions of Escudos) & 98,139 & 105,625 & 116,276 & 116,276 & 129,367 & 144,883 & 163,246 \\
\hline
\end{tabular}

Sources: Ministry of Finance and Public Administration, Bank of Cape Verde, and IMF staff estimates and projections.

${ }^{1}$ The energy subsidies recorded in 2007 were incurred in previous periods.

2 The capital expenditure budget is typically underexecuted.

${ }^{3}$ Overall balance (including grants) - total expenditure + domestic and external interest payments.

${ }^{4}$ Domestic revenue - recurrent expenditure.

${ }^{5}$ External grants + net foreign financing.

${ }^{6}$ Reflects borrowing from the pension fund and scheduling of payments to energy companies. 
Table 4. Cape Verde: Balance of Payments, 2006-13

(Millions of Cape Verde escudos, unless otherwise indicated)

\begin{tabular}{|c|c|c|c|c|c|c|c|c|}
\hline & 2006 & 2007 & 2008 & 2009 & 2010 & 2011 & 2012 & 2013 \\
\hline & & Est. & \multicolumn{6}{|c|}{ Projections } \\
\hline Current account balance (including official transfers) & $-5,259$ & $-10,630$ & $-12,150$ & $-14,339$ & $-17,103$ & $-14,894$ & $-20,631$ & $-24,732$ \\
\hline Trade balance & $-40,654$ & $-53,501$ & $-62,113$ & $-71,178$ & $-81,797$ & $-88,282$ & $-102,969$ & $-117,794$ \\
\hline Exports, f.o.b. & 8,429 & 6,134 & 6,981 & 7,242 & 7,487 & 7,788 & 8,132 & 8,649 \\
\hline Imports, f.o.b. & $-49,083$ & $-59,635$ & $-69,094$ & $-78,420$ & $-89,285$ & $-96,070$ & $-111,101$ & $-126,443$ \\
\hline Services (net) & 13,822 & 20,195 & 27,689 & 34,201 & 40,019 & 48,137 & 54,780 & 63,186 \\
\hline Credit & 35,523 & 44,011 & 53,638 & 63,351 & 72,941 & 84,264 & 96,124 & 110,281 \\
\hline Of which: tourism & 19,097 & 26,851 & 35,345 & 43,764 & 51,503 & 60,273 & 69,368 & 80,060 \\
\hline Debit & $-21,700$ & $-23,816$ & $-25,949$ & $-29,149$ & $-32,922$ & $-36,127$ & $-41,344$ & $-47,095$ \\
\hline Income (net) & $-3,952$ & $-2,128$ & $-2,243$ & $-2,546$ & $-3,016$ & $-4,003$ & $-4,618$ & $-5,304$ \\
\hline Credit & 1,627 & 1,953 & 2,228 & 2,351 & 2,783 & 2,666 & 2,906 & 3,167 \\
\hline Debit & $-5,579$ & $-4,081$ & $-4,471$ & $-4,896$ & $-5,799$ & $-6,669$ & $-7,524$ & $-8,472$ \\
\hline Government interest & -522 & -520 & -566 & -664 & -822 & -991 & $-1,158$ & $-1,312$ \\
\hline Interest by other sectors & $-2,443$ & $-1,688$ & $-1,727$ & $-1,711$ & $-2,040$ & $-2,246$ & $-2,359$ & $-2,477$ \\
\hline Income on direct investment and other income & $-2,614$ & $-1,873$ & $-2,178$ & $-2,522$ & $-2,937$ & $-3,431$ & $-4,007$ & $-4,683$ \\
\hline Current transfers (net) & 25,525 & 24,804 & 24,516 & 25,183 & 27,691 & 29,254 & 32,176 & 35,180 \\
\hline Government & 4,310 & 5,083 & 3,847 & 2,719 & 2,809 & 2,482 & 2,626 & 2,758 \\
\hline Other & 21,215 & 19,721 & 20,669 & 22,464 & 24,883 & 26,772 & 29,550 & 32,422 \\
\hline Capital and financial account (net) & 10,871 & 19,657 & 17,624 & 20,480 & 22,028 & 23,051 & 29,427 & 34,170 \\
\hline Capital transfers & 1,540 & 2,243 & 3,418 & 4,150 & 4,921 & 2,703 & 3,040 & 3,464 \\
\hline Government & 1,540 & 2,219 & 3,418 & 4,150 & 4,921 & 2,703 & 3,040 & 3,464 \\
\hline Other & 0 & 0 & 0 & 0 & 0 & 0 & 0 & 0 \\
\hline Direct investment (net) & 9,722 & 10,378 & 10,996 & 13,039 & 16,080 & 18,468 & 21,893 & 25,413 \\
\hline Portfolio investment & 13 & 561 & 550 & 550 & 550 & 550 & 550 & 550 \\
\hline Government & 2,266 & 1,959 & 3,273 & 4,249 & 4,829 & 5,103 & 5,775 & 5,793 \\
\hline Trust Fund & 0 & 0 & 0 & 0 & 0 & 0 & 0 & 0 \\
\hline Net official flows & 2,266 & 1,959 & 3,273 & 4,249 & 4,829 & 5,103 & 5,775 & 5,793 \\
\hline Disbursements & 4,240 & 3,779 & 5,204 & 6,229 & 7,018 & 7,746 & 8,837 & 10,069 \\
\hline Amortization & $-1,974$ & $-1,820$ & $-1,931$ & $-1,980$ & $-2,189$ & $-2,644$ & $-3,063$ & $-4,276$ \\
\hline Other & 0 & 0 & 0 & 0 & 0 & 0 & 0 & 0 \\
\hline Other investments & $-2,670$ & 4,518 & -613 & $-1,508$ & $-4,352$ & $-3,772$ & $-1,831$ & $-1,051$ \\
\hline Commercial banks & $-2,543$ & -811 & -393 & 8 & 8 & 8 & 8 & 8 \\
\hline Commercial credit (net) & 189 & 439 & 0 & 0 & 0 & 0 & 0 & 0 \\
\hline Other & -316 & 4,890 & -220 & $-1,516$ & $-4,360$ & $-3,781$ & $-1,839$ & $-1,059$ \\
\hline Net errors and omissions & -647 & $-1,907$ & 0 & 0 & 0 & 0 & 0 & 0 \\
\hline Overall balance & 4,965 & 7,120 & 5,474 & 6,140 & 4,925 & 8,158 & 8,796 & 9,438 \\
\hline Financing & $-4,965$ & $-7,120$ & $-5,474$ & $-6,140$ & $-4,925$ & $-8,158$ & $-8,796$ & $-9,437$ \\
\hline Gross international reserves ( - accumulation) & $-5,044$ & $-7,120$ & $-5,474$ & $-6,140$ & $-4,925$ & $-8,158$ & $-8,796$ & $-9,437$ \\
\hline Of which: IMF (net) & -96 & -79 & -105 & -113 & -169 & -194 & -180 & -139 \\
\hline Exceptional financing & 78 & 0 & 0 & 0 & 0 & 0 & 0 & 0 \\
\hline Financing gap & 0 & 0 & 0 & 0 & 0 & 0 & 0 & 0 \\
\hline \multicolumn{9}{|l|}{ Memorandum items: } \\
\hline Current account (including official transfers; percent of GDP) & -5.0 & -9.1 & -9.4 & -9.9 & -10.5 & -8.3 & -10.0 & -10.6 \\
\hline Current account (excluding official transfers; percent of GDP) & -9.1 & -13.5 & -12.4 & -11.8 & -12.2 & -9.6 & -11.3 & -11.7 \\
\hline Overall balance (percent of GDP) & 4.7 & 6.1 & 4.2 & 4.2 & 3.0 & 4.5 & 4.3 & 4.0 \\
\hline Gross international reserves & 21,304 & 28,424 & 33,898 & 40,038 & 44,964 & 53,121 & 61,917 & 71,355 \\
\hline Months of current year's import of goods and services & 3.6 & 4.1 & 4.3 & 4.5 & 4.4 & 4.8 & 4.9 & 4.9 \\
\hline Months of next year's import of goods and services & 3.1 & 3.6 & 3.8 & 3.9 & 4.1 & 4.2 & 4.3 & 4.4 \\
\hline External public debt & 49,869 & 54,843 & 57,538 & 61,423 & 65,699 & 70,097 & 75,469 & 80,436 \\
\hline External aid (grants and loans; percent of GDP) & 9.6 & 9.5 & 9.6 & 9.0 & 9.0 & 7.2 & 7.1 & 7.0 \\
\hline
\end{tabular}

Sources: Bank of Cape Verde; and IMF staff estimates and projections. 
Table 5. Cape Verde: Monetary Survey, 2005-11

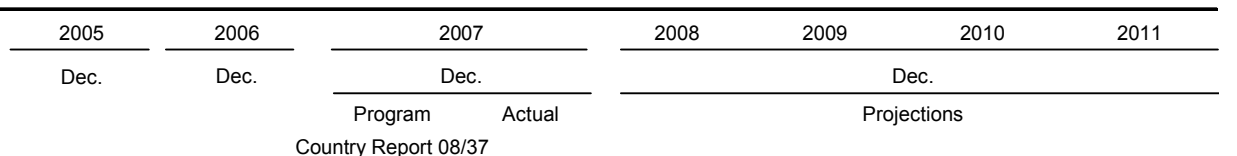

(Millions of Cape Verde escudos, unless otherwise specified)

\begin{tabular}{|c|c|c|c|c|c|c|c|c|}
\hline $\begin{array}{l}\text { Net foreign assets } \\
\text { Of which: excluding the effect of a purchase of a }\end{array}$ & 21,889 & 25,138 & 30,883 & 30,902 & 37,176 & 43,421 & 48,507 & 56,851 \\
\hline Portuguese credit to Electra in 2006 & 21,889 & 29,532 & & & & & & \\
\hline Foreign assets & 27,549 & 31,285 & 37,958 & 38,643 & 44,945 & 51,214 & 56,270 & 64,561 \\
\hline Of which: foreign reserves & 16,260 & 21,304 & 29,128 & 28,424 & 33,898 & 40,038 & 44,964 & 53,121 \\
\hline Foreign liabilities & $-5,660$ & $-6,147$ & $-7,074$ & $-7,741$ & $-7,769$ & $-7,793$ & $-7,763$ & $-7,711$ \\
\hline Net domestic assets & 50,754 & 60,398 & 66,134 & 63,702 & 68,553 & 75,517 & 86,100 & 92,393 \\
\hline Net domestic credit & 60,193 & 70,487 & 76,266 & 71,445 & 78,821 & 86,311 & 97,364 & 104,149 \\
\hline Net claims on general government & 25,697 & 25,632 & 20,465 & 19,640 & 19,460 & 18,257 & 17,325 & 15,556 \\
\hline Claims on the Trust Fund (TCMFs) & 11,038 & 11,038 & 11,038 & 11,038 & 11,038 & 11,038 & 11,038 & 11,038 \\
\hline Net claims on the central government & 15,207 & 15,392 & 10,226 & 8,887 & 8,698 & 7,485 & 6,548 & 4,774 \\
\hline Credit to central government & 20,044 & 19,470 & 15,709 & 16,082 & 17,392 & 16,180 & 15,243 & 13,469 \\
\hline Deposits of central government & $-4,837$ & $-4,078$ & $-5,483$ & $-7,195$ & $-8,695$ & $-8,695$ & $-8,695$ & $-8,695$ \\
\hline Of which: project deposits & -351 & -716 & -277 & -658 & -277 & -277 & -277 & -277 \\
\hline Net claims on local government & 21 & -311 & -311 & 229 & 238 & 248 & 258 & 268 \\
\hline Net claims on other government agencies (INPS) & -569 & -488 & -488 & -514 & -514 & -514 & -519 & -524 \\
\hline Credit to the economy & 34,496 & 44,855 & 55,801 & 51,804 & 59,361 & 68,054 & 80,039 & 88,593 \\
\hline $\begin{array}{l}\text { credit to Electra and subsequent off-loading } \\
\text { on the domestic securities market }\end{array}$ & 34,496 & 40,461 & & & & & & \\
\hline Credit to public enterprises & 431 & 634 & 678 & 543 & 563 & 589 & 617 & 645 \\
\hline Credit to private sector & 34,040 & 44,205 & 55,108 & 51,256 & 58,793 & 67,459 & 79,417 & 87,942 \\
\hline Claims on nonbank financial institutions & 26 & 16 & 16 & 6 & 6 & 6 & 6 & 6 \\
\hline Other items (net) & $-9,439$ & $-10,089$ & $-10,133$ & $-7,742$ & $-10,269$ & $-10,794$ & $-11,264$ & $-11,756$ \\
\hline Broad money (M2) & 72,643 & 85,536 & 97,017 & 94,605 & 105,729 & 118,938 & 134,608 & 149,244 \\
\hline Narrow money (M1) & 28,718 & 35,860 & 40,673 & 40,336 & 45,079 & 50,711 & 57,392 & 63,632 \\
\hline Currency outside banks & 7,634 & 7,731 & 8,769 & 8,388 & 9,246 & 10,301 & 11,578 & 12,775 \\
\hline Demand deposits & 21,084 & 28,129 & 31,904 & 31,949 & 35,833 & 40,411 & 45,814 & 50,858 \\
\hline Quasimoney & 40,566 & 45,505 & 51,613 & 48,299 & 53,978 & 60,722 & 68,722 & 76,194 \\
\hline Time deposits & 38,390 & 43,334 & 49,151 & 45,785 & 51,168 & 57,561 & 65,144 & 72,227 \\
\hline Other quasimonetary deposits & 2,176 & 2,170 & 2,462 & 2,515 & 2,810 & 3,161 & 3,578 & 3,967 \\
\hline \multirow[t]{2}{*}{ Foreign currency deposits } & 3,359 & 4,172 & 4,731 & 5,969 & 6,671 & 7,505 & 8,493 & 9,417 \\
\hline & \multicolumn{8}{|c|}{ (Change in percent of broad money 12 months earlier) } \\
\hline Net foreign assets & 12.9 & 4.5 & 6.7 & 6.7 & 6.6 & 5.9 & 4.3 & 6.2 \\
\hline Net domestic assets & 2.7 & 13.3 & 6.7 & 3.9 & 5.1 & 6.6 & 8.9 & 4.7 \\
\hline Net domestic credit & 4.6 & 14.2 & 6.8 & 1.1 & 7.8 & 7.1 & 9.3 & 5.0 \\
\hline Net claims on the central government & 0.2 & 0.3 & -6.0 & -7.6 & -0.2 & -1.1 & -0.8 & -1.3 \\
\hline Credit to the economy & 4.6 & 14.3 & 12.8 & 8.1 & 8.0 & 8.2 & 10.1 & 6.4 \\
\hline Credit to public enterprises & 0.4 & 0.3 & 0.1 & -0.1 & 0.0 & 0.0 & 0.0 & 0.0 \\
\hline Credit to private sector & 4.2 & 14.0 & 12.7 & 8.2 & 8.0 & 8.2 & 10.1 & 6.3 \\
\hline Other items (net) & -1.9 & -0.9 & -0.1 & 2.7 & -2.7 & -0.5 & -0.4 & -0.4 \\
\hline Broad money (M2) & 15.5 & 17.7 & 13.4 & 10.6 & 11.8 & 12.5 & 13.2 & 10.9 \\
\hline \multicolumn{9}{|l|}{ Selected monetary indicators: } \\
\hline Income velocity of money ${ }^{7}$ & 1.317 & 1.336 & 1.259 & 1.291 & 1.292 & 1.290 & 1.288 & 1.270 \\
\hline Emigrant deposits & 28,318 & 31,293 & 35,494 & 33,262 & 35,058 & 37,060 & 39,250 & 40,533 \\
\hline (as percent total deposits) & 43.6 & 40.2 & $\ldots$ & 38.6 & 36.3 & 34.1 & 31.9 & 29.7 \\
\hline Excess reserves /total deposits (percent) & 2.1 & 1.3 & 1.5 & 2.2 & 2.2 & 2.1 & 2.1 & 2.1 \\
\hline Money multilplier (M2/M0) & 3.44 & 3.92 & 4.19 & 3.95 & 3.91 & 3.92 & 3.93 & 3.93 \\
\hline Credit to the economy (percentage change) & 9.0 & 30.0 & 24.4 & 15.5 & 14.6 & 14.6 & 34.8 & 30.2 \\
\hline
\end{tabular}

Sources: Bank of Cape Verde, and IMF staff estimates and projections.

${ }^{7}$ Velocity is nominal GDP devided by average end period broad money. Velocity declines gradually because of financial deepening.

CInternational Monetary Fund. Not for Redistribution 
Table 6. Cape Verde: Central Bank Survey, 2005-11

\begin{tabular}{|c|c|c|c|c|c|c|c|c|}
\hline & \multirow{4}{*}{$\begin{array}{l}2005 \\
\text { Dec. }\end{array}$} & \multirow{4}{*}{$\begin{array}{c}2006 \\
\text { Dec. } \\
\text { Actual }\end{array}$} & \multirow{2}{*}{\multicolumn{2}{|c|}{$\begin{array}{l}2007 \\
\text { Dec. }\end{array}$}} & 2008 & 2009 & 2010 & 2011 \\
\hline & & & & & \multicolumn{4}{|c|}{ Dec. } \\
\hline & & & Program & Actual & \multicolumn{4}{|c|}{ Projections } \\
\hline \multicolumn{7}{|c|}{ Country Report 08/37 } & & \\
\hline & \multicolumn{8}{|c|}{ (Millions of Cape Verde escudos, unless otherwise specified) } \\
\hline Net foreign assets & 15,308 & 20,390 & 28,287 & 27,569 & 33,149 & 39,402 & 44,496 & 52,847 \\
\hline Of which: net international reserves & 15,109 & 20,216 & 28,113 & 27,414 & 32,993 & 39,246 & 44,340 & 52,691 \\
\hline Foreign assets & 16,523 & 21,536 & 29,360 & 28,632 & 34,106 & 40,246 & 45,172 & 53,329 \\
\hline Foreign liabilities & $-1,215$ & $-1,146$ & $-1,073$ & $-1,062$ & -957 & -845 & -676 & -482 \\
\hline Net domestic assets & 5,828 & 1,454 & $-5,128$ & $-3,613$ & $-6,130$ & $-9,073$ & $-10,224$ & $-14,839$ \\
\hline Net domestic credit & 7,678 & 3,518 & $-3,023$ & $-1,397$ & $-3,870$ & $-6,768$ & $-7,872$ & $-12,440$ \\
\hline Trust Fund claims & 4,605 & 4,605 & 4,605 & 4,605 & 4,605 & 4,605 & 4,605 & 4,605 \\
\hline Net claims on central government & 1,882 & 1,748 & 239 & -607 & $-2,107$ & $-2,107$ & $-2,107$ & $-2,107$ \\
\hline Credit to central government & 4,779 & 3,739 & 3,739 & 3,739 & 3,739 & 3,739 & 3,739 & 3,739 \\
\hline Deposits of central government & $-2,896$ & $-1,990$ & $-3,500$ & $-4,346$ & $-5,846$ & $-5,846$ & $-5,846$ & $-5,846$ \\
\hline Of which: project accounts & -351 & -716 & -277 & -658 & -277 & -277 & -277 & -277 \\
\hline foreign currency deposits & $-1,347$ & -682 & -682 & -607 & -607 & -607 & -607 & -607 \\
\hline Claims on local government & 0 & 0 & 0 & 0 & 0 & 0 & 0 & 0 \\
\hline Credit to the economy & 1,163 & 1,147 & 1,271 & 1,088 & 1,093 & 1,099 & 1,104 & 1,109 \\
\hline Credit to public enterprises & 54 & 47 & 47 & 39 & 39 & 39 & 39 & 39 \\
\hline Credit to private sector & 1,094 & 1,091 & 1,215 & 1,046 & 1,051 & 1,056 & 1,062 & 1,067 \\
\hline Claims on nonbank financial institutions & 15 & 9 & 9 & 3 & 3 & 3 & 3 & 3 \\
\hline Credit to commercial banks & 27 & $-3,983$ & $-9,137$ & $-6,483$ & $-7,461$ & $-10,364$ & $-11,474$ & $-16,047$ \\
\hline Other items (net) & $-1,850$ & $-2,063$ & $-2,104$ & $-2,216$ & $-2,260$ & $-2,305$ & $-2,351$ & $-2,398$ \\
\hline Assets & 2,481 & 2,791 & 2,847 & 2,897 & 2,955 & 3,014 & 3,074 & 3,136 \\
\hline Liabilities & 4,332 & 4,854 & 4,951 & 5,113 & 5,215 & 5,319 & 5,426 & 5,534 \\
\hline Reserve money (M0) & 21,136 & 21,845 & 23,160 & 23,957 & 27,019 & 30,329 & 34,272 & 38,008 \\
\hline Currency outside banks & 7,634 & 7,731 & 8,769 & 8,388 & 9,246 & 10,301 & 11,578 & 12,775 \\
\hline Cash in vaults & 1,058 & 1,457 & 1,169 & 1,595 & 1,786 & 2,011 & 2,277 & 2,526 \\
\hline Deposits of commercial banks & 12,443 & 12,654 & 13,219 & 13,966 & 15,979 & 18,009 & 20,408 & 22,699 \\
\hline Deposits of private sector & 0 & 0 & 0 & 0 & 0 & 0 & 0 & 0 \\
\hline Deposits of other financial institutions & 2 & 3 & 3 & 8 & 8 & 8 & 8 & 8 \\
\hline Gross international reserves (€ millions) & 147.4 & 193.1 & 264.1 & 257.7 & 307.3 & 363.0 & 407.6 & 481.6 \\
\hline Net international reserves (€ millions) & 137.0 & 183.3 & 254.9 & 248.5 & 299.1 & 355.8 & 402.0 & 477.7 \\
\hline Reserve money (12-month change in percent) & 14.3 & 3.4 & 6.0 & 9.7 & 12.8 & 12.3 & 13.0 & 10.9 \\
\hline
\end{tabular}

Sources: Bank of Cape Verde, and IMF staff estimates and projections. 
Table 7. Cape Verde: Deposit Money Bank Survey, 2005-11

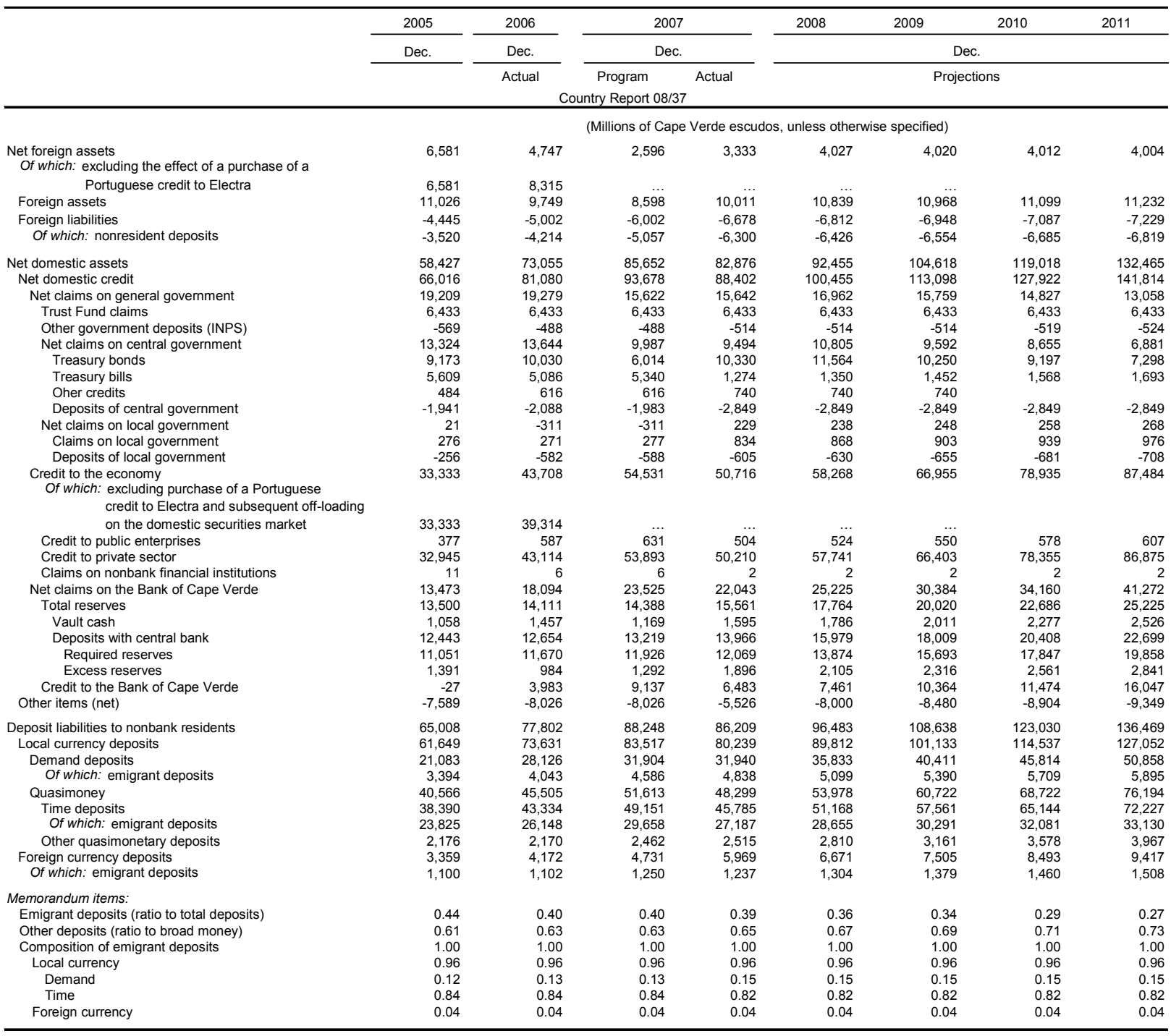

Sources: Bank of Cape Verde, and IMF staff estimates and projections. 
Table 8. Cape Verde: Financial Soundness of the Banking Sector, 2004-07

(End-year; percent unless otherwise indicated)

\begin{tabular}{|c|c|c|c|c|}
\hline Indicator & 2004 & 2005 & 2006 & 2007 \\
\hline \multicolumn{5}{|l|}{ Capital adequacy } \\
\hline Regulatory capital to risk-weighted assets & 13.3 & 12.1 & 11.1 & 11.4 \\
\hline Regulatory tier 1 capital to risk-weighted assets & 14.6 & 13.4 & 11.3 & 11.9 \\
\hline \multicolumn{5}{|l|}{ Asset quality } \\
\hline Nonperforming loans to total loans & 7.2 & 6.3 & 3.9 & 8.8 \\
\hline Nonperforming loans net of provisions to capital & 0.4 & -2.5 & -1.7 & 48.9 \\
\hline Provisions to nonperforming loans & 99.3 & 104.9 & 104.1 & 47.5 \\
\hline \multicolumn{5}{|l|}{ Earnings and profitability } \\
\hline Return on assets & 0.7 & 0.5 & 0.9 & 1.8 \\
\hline Return on equity & 12.3 & 9.7 & 16.4 & 31.5 \\
\hline Interest margin to gross income & 65.5 & 62.7 & 67.2 & 73.6 \\
\hline Noninterest expenses to gross income & 57.6 & 61.2 & 54.5 & 49.9 \\
\hline \multicolumn{5}{|l|}{ Liquidity } \\
\hline Liquid assets to total assets ${ }^{2}$ & 48.1 & 46.2 & 44.4 & 44.6 \\
\hline Liquid assets to short-term liabilities ${ }^{2}$ & 176.9 & 170.2 & 111.5 & 108.5 \\
\hline \multicolumn{5}{|l|}{ Additional indicators } \\
\hline Government deposits over total deposits & 3.2 & 4.1 & 4.1 & 4.5 \\
\hline Emigrant deposits over total deposits & 43.0 & 41.9 & 38.8 & 37.1 \\
\hline Demand deposits over total deposits & 31.5 & 32.4 & 36.2 & 37.0 \\
\hline Credit to private sector over total deposits & 54.1 & 50.7 & 55.4 & 58.2 \\
\hline Personnel cost over cost of operations & 50.4 & 52.1 & $\ldots$ & $\ldots$ \\
\hline Spread (90 day lending - time deposit rate) & 8.0 & 7.9 & 8.1 & 8.2 \\
\hline Spread (emigrant deposits - euro area deposit rate) & 4.7 & 3.2 & 2.3 & 2.1 \\
\hline
\end{tabular}

Sources: Bank of Cape Verde, International Financial Statistics, and IMF staff estimates.

${ }^{1}$ The NPL ratio for the four onshore banks increased in 2007 because of new stricter loan classification criteria.

${ }^{2}$ Liquid assets include cash in vault and marketable securities. Short-term liabilities include demand deposits. 
Table 9. Cape Verde: Millennium Development Goals

1990

\section{Goal 1. Eradicate extreme poverty and hunger.}

Target 1: Halve between 1990 and 2015, the proportion of people whose income is less than US\$1 a day.

1. Population below US\$ 1 a day (percent)

2. Poverty gap ratio at US\$ 1 a day (percent)

3. Share of income or consumption held by poorest 20 percent (percent)

3a. Percentage of poor, 2001-02

3b. Incidence of absolute poverty

Target 2: Halve, between 1990 and 2015, the proportion of people suffering hunger.

4. Prevalence of child malnutrition (percent of children under 5)

5. Population below minimum level of dietary energy consumption (percent)

\section{Goal 2. Achieve universal primary education.}

Target 3: Ensure that, by 2015, children will be able to complete a full course of primary schooling

6. Net primary enrollment ratio (percent of relevant age group)

7. Percentage of cohort reaching grade 5

8. Youth literacy rate (percent age 15-24)

\section{Goal 3. Promote gender equality and empower women.}

Target 4: Eliminate gender disparity in primary and secondary education preferably by 2005 and to all levels of education by 2015 .

9. Ratio of girls to boys in primary and secondary education (percent)

10. Ratio of young literate females to males (percent ages 15-24)

11. Share of women employed in the nonagricultural sector (percent)

12. Proportion of seats held by women in the national parliament (percent)

\section{Goal 4. Reduce child mortality.}

Target 5: Reduce by two-thirds between 1990 and 2015, the under 5 mortality rate

13. Under 5 mortality rate (per 1,000$)$

14. Infant mortality rate (per 1,000 live births)

15. Immunization against measles (percent of children under 12 months)

$\begin{array}{lllll}60.0 & 50.0 & 38.0 & 36.0 & 35.0 \\ 45.0 & 37.0 & 29.0 & 30.0 & 26.0\end{array}$

Goal 5. Improve maternal health

Target 6: Reduce by three-quarters, between 1990 and 2015, the maternal mortality ratio.

16. Maternal mortality ratio (modeled estimate, per 100,000 live births)

17. Proportion of births attended by skilled health personnel

$\begin{array}{rrrrrr}\ldots & 96.1 & \ldots & \ldots & 99.9 & 100.0 \\ 87.5 & 90.4 & 93.3 & 93.8 & 93.8 & 100.0 \\ 39.1 & \ldots & \ldots & \ldots & \ldots & \ldots \\ 12.0 & 11.0 & 11.0 & 11.0 & 11.0 & \ldots\end{array}$

\section{Goal 6. Combat HIVIAIDS, malaria and other diseases.}

Target 7: Halt by 2015, and begin to reverse, the spread of HIVIAIDS.

18. HIV prevalence among females (percent ages 15-24)

19. Contraceptive prevalence rate (percent of women ages 15-49)

20. Number of children orphaned by HIVIAIDS

Target 8: Halt by 2015 , and begin to reverse, the incidence of malaria and other major diseases.

23. Incidence of tuberculosis (per 100,000 people)

24. Tuberculosis cases detected under DOTS (percent) 
Table 9. Cape Verde: Millennium Development Goals (concluded)

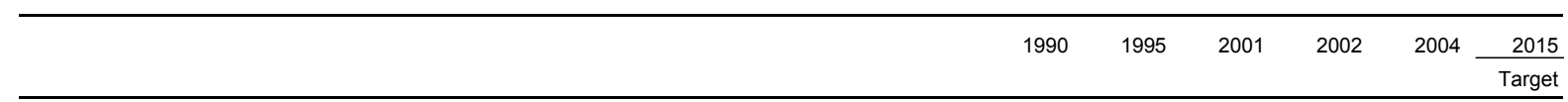

\section{Goal 7. Ensure environmental sustainability.}

Target 9: Integrate the principles of sustainable development into policies and programs. Reverse the loss of environmental resources.

25. Forest area (percent of total land area)

26. Nationally protected areas (percent of total land area)

27. GDP per unit of energy use (PPP \$ per kg oil equivalent)

28. $\mathrm{CO} 2$ emissions (metric tons per capita)

Target 10: Halve by 2015 the proportion of people without access to safe drinking water.

30. Access to improved water source (percent of population)

Target 11: Achieve by 2020 significant improvement for at least 100 million slum dwellers

31. Access to improved sanitation (percent of population)

32. Access to secure tenure (percent of population)

\section{Goal 8. Develop a global partnership for development. ${ }^{3}$}

Target 16: Develop and implement strategies for productive work for youth

45. Unemployment rate of population ages 15-24 (total)

Target 18: Make available new technologies, especially information and communications.

47. Fixed line and mobile telephones (per 1,000 people)

48. Personal computers (per 1,000 people)

8.7

$0.0-0.0$
.0

$\begin{array}{lll}0.2 & 0.3 & 0.3\end{array}$

Sources: World Bank, and Fund staff estimates.

${ }^{1}$ Absolute poverty measures the number of people in 1988 and 2002 whose income is below the 1988 national poverty line, indexed for inflation

${ }^{2}$ Data for 1988.

${ }^{3}$ Targets $12-15$ and indicators $29,33-44$ are excluded because they cannot be measured on a country specific basis. These are related to official development, assistance, market access, and the HIPC initiative. Indicators 21 and 22 are not relevant for Cap

\section{CInternational Monetary Fund. Not for Redistribution}


Table 10. Cape Verde: Proposed Work Program 2008-09

\begin{tabular}{|l|l|l|}
\hline Mission Date & Purpose & Board Review \\
\hline September 2008 & $\begin{array}{l}\text { Discussions on the fifth review } \\
\text { against end-June 2008 } \\
\text { assessment criteria }\end{array}$ & End-November 2008 \\
February 2009 & $\begin{array}{l}\text { Discussions on the sixth review } \\
\text { against end-December 2008 } \\
\text { assessment criteria }\end{array}$ & End-April 2009 \\
\hline
\end{tabular}


APPENDiX. LETTER OF INTENT

June 9, 2008

Mr. Dominique Strauss-Kahn

Managing Director

International Monetary Fund

$70019^{\text {th }}$ Street N.W.

Washington DC 20431, USA

Dear Mr. Strauss-Kahn:

1. Discussions for the fourth review of the Policy Support Instrument (PSI) were held in Praia during March 5-19, 2008. This letter of intent (LOI) reviews implementation to date of the Cape Verde government's reform program under the country's PSI which was approved by the IMF Executive Board in July 2006. It affirms our commitment to the policy priorities that were laid out in detail in our Memorandum of Economic and Financial Policies (MEFP) of November 2007, and describes policy developments since the third review of the PSI and prospects for the remainder of 2008 and early 2009.

2. The government believes that the PSI program provides firm support to enforce its policies for macroeconomic stability and the exchange rate peg and promote growth. By fostering a disciplined fiscal framework which has yielded significant fiscal consolidation in recent years, the program has achieved a large reduction in domestic debt ( 9 percentage points of GDP in 2007) and created the fiscal room needed to increase infrastructure spending to ease bottlenecks to growth. At the same time, the program has enabled significant buildup of official reserves, which together with the debt reduction, will enable Cape Verde to prepare for possible declines in concessional external financing following the country's graduation from Least-Developed-Country status in January 2008.

\section{Recent economic developments and outlook}

3. Economic activity was strong in $2006 / 07$ and we expect good growth in $\mathbf{2 0 0 8 / 0 9}$ underpinned by further growth in tourism investment and other services, and by public infrastructure investment. Real GDP growth rate peaked at 10.8 percent in 2006 boosted by tourism, telecommunications, and construction sectors, and is estimated at about 7 percent in 2007. Real GDP growth for 2008 and 2009 is forecast to average about $6 \frac{1}{2}$ percent which takes into account the global economic slowdown. Consumer price inflation (annual average) in 2007 declined to 4.4 percent from 5.4 in 2006, despite poor rainfall and should moderate even further to trend value of $2 \frac{1}{2}-3 \frac{1}{2}$ percent in 2008 and 2009 in line with those of our major trading partners.

\section{Program performance}

4. Performance on quantitative assessment criteria for end-December 2007 has exceeded expectations (Table 1). In particular, the program ceiling on net domestic borrowing was observed by a wide margin reflecting continued expenditure restraint and buoyant tax revenue collections thanks to strong economic growth, improvements in tax administration, and higher-than-expected asset sales. Also, the program's international 
reserves target was met by a large margin even though reserve accumulation slowed down somewhat in the final quarter of 2007 driven by slowdown in FDI inflows.

\section{The government is proceeding with the implementation of the structural measures in the program (Table 2).}

- Implementation of the structural benchmarks on the General Tax Code and Judicial Process Code was met with a five-month delay from end-December 2007 due both to longerthan-expected public consultation process to forge a consensus before submission to Parliament, as well as unanticipated technical problems that arose during the final stages of the legislative drafting. Subsequently, the government with further technical assistance from the IMF's Legal Department finalized and submitted the drafts to the Council of Ministers in May and submitted them to Parliament in June 2008. The income tax code (personal and corporate) will be aligned with the government's planned legislation on rationalizing tax incentives as part of a larger package to reduce economic distortions and make the income tax system more business friendly. Specifically, the government will examine existing tax holidays, and introduce loss and carry forward provisions and accelerated depreciation as part of rationalization of tax incentives and submit the new income tax codes to Parliament in October as part of the 2009 budget.

- $\quad$ On energy sector reform, the economic regulatory agency (ARE) finalized and posted on ARE's website the mechanism for setting the base utility tariffs for electricity and water (an assessment criterion under the PSI) by end-March 2008. The new tariffs were determined after a lengthy analysis of Electra's costs and efficiency gains targets. Specifically, by March 28 2008, (i) the technical specifications for the base utility tariffs was agreed upon between Electra and ARE; (ii) the details of the base tariff setting mechanism were posted on ARE's website and (iii) base tariff levels were brought in line with the agreed mechanism. However, the current fuel pricing formula is complex and not very transparent and this complicates its continuous application especially given the different cost structure of the two oil companies (Shell and Enacol). As a result, the government is working on a new fuel formula and will finalize and publish it in June 2008 (a structural benchmark for March). The delay in implementing the latter measure reflects lack of funding for a energy consultant to set up and calibrate the new pricing model and the financing only got secured in early March 2008.

- The BCV has also made progress on the structural benchmarks on financial sector reform. The PSI benchmark for June 2007 on the implementation of the recommendations of the financial-sector task force was met late 2007 with the publication of a new risk-oriented regulation, which broadly aligned the regulatory requirements for onshore and offshore banks. The benchmark for March 2008 on the establishment of the financial intelligence unit was met in January 2008, and the legislative drafting of the AML/CFT was concluded at endMarch 2008. 


\section{Economic policies for the remainder of 2008 and for 2009}

6. The government will continue to focus on enhancing macroeconomic stability and implementing structural reforms to improve productivity growth and encourage private-sector led development. Fiscal and monetary policies are consistent with program goals and supportive of the peg. In particular, public debt will continue to come down as a share of GDP and international reserves are expected to buildup further. The 2008 program aims at promoting structural reforms especially in fiscal accounting, budget execution and control, and arrears prevention, as well as strengthening of the financial sector and improving energy sector regulation.

\section{Fiscal and Public Financial Management issues}

7. Continued fiscal consolidation remains crucial to our macroeconomic program and the 2008 budget aims at a further sizable reduction of the domestic debt-to-GDP ratio.

- $\quad$ The budget projections for revenues and expenditures are prudent, with tax revenues and the wage bill planned to grow by less than nominal GDP relative to the 2007 budget. As the 2008 budget does not plan additional net domestic borrowing in 2008, the net domestic debt-to-GDP ratio is projected to continue to decline below 20 percent by end-2008, with the original target reached two years ahead of schedule. Going forward, we are committed to continue to reduce public debt as a share of GDP and to keep it on an appropriate path consistent with the medium term baseline debt path agreed with the IMF. Using our mediumterm fiscal framework, we are considering increasing capital expenditure modestly to ease infrastructure bottlenecks for both transportation and the energy sector. Consistent with the government's overall investment program, our planned increases in capital spending, which also recognizes the need for a comprehensive overhaul of the energy sector, will be in line with the strengthening of our public financial management (PFM) and debt management.

- The rationalization of tax incentives is also a high priority to the government since it will improve procedures to grant exemptions and repeal some of the current exemptions. Reforming the corporate income tax rate will help to muster public support for rationalizing tax exemptions. To this end, we reiterate our request for technical assistance to the IMF to help us with a framework which will underpin the economic criteria for rationalizing tax incentives.

8. The government remains fully committed to moving ahead with its program of strengthening public sector financial management as outlined in our MEFP for the third review of the PSI. Thus, we agreed to include a new structural measure in the program which will submit a simplified medium-term fiscal framework to the Council of Ministers in the 2009 budget preparation cycle and publish it on the Ministry of Finance website in November 2008 to help to anchor fiscal policy on a medium-term perspective. This measure will help the government to build capacity for formulation of a medium-term fiscal policy, lay the basis for implementation of a medium-term expenditure framework (MTEF), program budgeting and a medium-term investment program (MTIP) in line with the forthcoming PRSP-II for 2008-11. 
9. Strengthening our debt management capacity is also a high priority. At present our debt management office has a number of resource constraints. A strengthened debt management strategy will underpin the government's borrowing program and the country's overall medium-term fiscal framework. In this context, the government reiterates its need for technical assistance from the IMF to strengthen debt management, which could include assistance to enhance our asset-liability management. On concessional financing, the government has extensively reached out through its various donor partners, including through several high level conferences to shore up concessional financing over the medium term. Most donors have responded positively by confirming that graduation from the UN's Least Developed Country status will not lead to an abrupt end to concessional aid. Thus, we will continue to look for concessional money to finance our planned increases in infrastructure spending. In line with our plans to strengthen our debt management office and strategy, the government will review thoroughly with the IMF the borrowing necessary to finance vital projects to ease infrastructure constraints on growth and help to decisively move ahead with the much needed reform of the energy sector.

\section{Monetary and financial sector issues}

10. Monetary management remains consistent with the program goal of building up foreign exchange reserves to support the peg to the Euro. Consistent with the exchange rate peg, the Bank of Cape Verde (BCV) will continue to adjust domestic interest rates in the short run to smooth out capital flows. The BCV's official policy rate will remain the interest rate offered on the 14-day bill. The government's objective is to increase reserves by about 0.1 month of prospective imports annually reaching over 4 months by 2013 .

\section{The BCV is strengthening the regulation and supervision of the financial sector.}

- $\quad$ All four onshore banks are fully compliant with the new strengthened prudential requirements. New bank regulations on capital ratios, provisioning and loan classification, credit risk assessment, and credit concentration were published in November 2007 and BCV has given banks a 5 year transitional period to meet the new requirement on provisions on non-performing loans. To further financial sector stability, the BCV agrees to a new structural benchmark to be included in the program which will establish a system to enhance the monitoring of external flows including non-resident deposits. Better monitoring of deposits is necessary to promptly detect potentially destabilizing capital flows and adjust interest rates as necessary to smooth out these capital flows. We will continue to study to what extent these deposits (or subsamples of these deposits) are interest sensitive.

- A new insurance sector regulation is being modernized to cover both life and non-life aspects of the insurance industry. Although the basic infrastructure on capital markets is in place, the operational and legal aspects are not yet fully developed and modernized including the Securities Code and the Company's Act. As a result, the capital market needs to be better oriented toward supporting economic development in Cape Verde. The government recognizes that the development of capital markets will enable domestic companies access funds from emigrants seeking investment opportunities other than emigrant deposits and is consistent with turning Cape Verde into an international financial centre. Thus, the government is working on these aspects, and will take further measures to minimize risks to the financial system before moving further with liberalization of financial flows. 


\section{Energy sector reform}

12. Despite the resource constraints that have caused delays in implementing the government's comprehensive plans to reform the energy sector, the reforms are steadily moving in the right direction. Following the approval of the new base utility tariff mechanism, there will be regular adjustment of these tariffs, which will ease Electra's cash flow problems, clear its arrears with suppliers, help the implementation of its investment plan, and stop the accrual of tariff deficits, a government contingent liability. Thus, consistent with the government's commitment in the MEFP for the $3^{\text {rd }}$ review of the PSI not to allow subsidies for energy products in the 2008 budget, ARE adjusted fuel prices by endMarch 2008. A new simplified and more transparent fuel pricing formula is also being prepared to be finalized and published in June 2008. One consideration is to base the new fuel formula on international benchmark prices, which will stop the accrual of fuel price deficits owed to the oil companies, and will be in line with the joint venture for the two oil suppliers into a joint logistics company to handle importation, storage and inter-island distribution of oil products by July 2008. As part of early deliverables on Electra's reform, Electra will also strengthen its revenue collection system, including putting in place prepaid meters. To provide financial assistance to Electra, with the help of donor assistance, the government will build five power plants and lend them on to Electra. The government is also considering management contracts with the private sector to improve Electra's management. We also recognize the potential role of public private partnerships (PPP) to boost investments in the energy sector; and will therefore strengthen the regulation for PPPs to ensure that the risk-sharing arrangement in these PPP prevents any contingent liability for the government in the future.

\section{Program monitoring and reporting}

\section{Under the PSI, the government will keep the IMF regularly updated on} economic and policy developments and will provide the data needed for adequate monitoring of the program. This extended LOI provides updates to our MEFP of November 2007 as follows: Program's quantitative targets for the end-June 2008 were reviewed and affirmed and targets were set for end-December 2008 (Table 1), and two new structural measures on public financial management and the financial sector in the program were included (Table 2). The fifth and sixth reviews of the PSI are scheduled to be completed by end-October 2008 and end-April 2009, respectively. During the period of the PSI, Cape Verde will consult with the IMF on the adoption of any measures that may be appropriate at the initiative of the government or whenever the Managing Director of the IMF requests such a consultation.

14. We authorize the IMF to publish this letter, and the related staff report and selected issues papers.

Sincerely yours,

$/ \mathrm{s} /$

Cristina Duarte

Minister of Finance and Public Administration. 
Table 1. Cape Verde: Quantitative Assessment Criteria and Benchmarks for 2007-08 Under the PSI ${ }^{1,2}$

\begin{tabular}{|c|c|c|c|c|c|c|c|c|}
\hline & \multicolumn{4}{|c|}{$\begin{array}{l}\text { Cumulative Flows from End-December, } 2006 \\
2007\end{array}$} & \multicolumn{4}{|c|}{$\begin{array}{l}\text { Cumulative Flows from End-December, } 2007 \\
2008\end{array}$} \\
\hline & \multicolumn{4}{|c|}{ Dec. } & \multirow{2}{*}{$\begin{array}{c}\text { March } \\
\text { Indicative } \\
\text { Target }\end{array}$} & \multirow{2}{*}{$\begin{array}{c}\text { June } \\
\text { Assessment } \\
\text { Criteria }\end{array}$} & \multirow{2}{*}{$\begin{array}{c}\text { Sep. } \\
\text { Indicative } \\
\text { Target }\end{array}$} & \multirow{2}{*}{$\begin{array}{c}\text { Dec. } \\
\text { Assessmen } \\
\text { Criteria }\end{array}$} \\
\hline & $\begin{array}{l}\text { Assessment } \\
\text { Criteria }\end{array}$ & $\begin{array}{l}\text { Assessment } \\
\text { Criteria } \\
\text { with adjusters } \\
\end{array}$ & Actual & $\begin{array}{l}\text { Level } \\
\text { Actual }\end{array}$ & & & & \\
\hline Quantitative targets & \multicolumn{8}{|c|}{ (Billions of Cape Verde escudos) } \\
\hline Ceiling on net domestic borrowing of the central government ${ }^{3}$ & -3.9 & -3.7 & -5.7 & $\ldots$ & -0.4 & -0.8 & -1.3 & -1.7 \\
\hline Ceiling on net domestic assets of the central bank ${ }^{4}$ & -3.0 & -3.2 & -5.1 & -3.6 & -0.6 & -1.3 & -2.0 & -2.5 \\
\hline \multirow[t]{2}{*}{$\begin{array}{l}\text { Ceiling on the accumulation of new domestic } \\
\text { payment arrears by the central government }\end{array}$} & 0.0 & 0.0 & 0.0 & $\ldots$ & 0.0 & 0.0 & 0.0 & 0.0 \\
\hline & \multicolumn{8}{|c|}{ (Millions of U.S. dollars) } \\
\hline $\begin{array}{l}\text { Ceiling on the accumulation of new external } \\
\text { payment arrears by the central government }{ }^{5}\end{array}$ & 0.0 & 0.0 & 0.0 & $\ldots$ & 0.0 & 0.0 & 0.0 & 0.0 \\
\hline $\begin{array}{l}\text { Ceiling on the contracting or guaranteeing of non- } \\
\text { concessional external debt with original maturity of } \\
\text { more than one year by the central government }{ }^{6}\end{array}$ & 35.0 & 35.0 & 0.1 & $\ldots$ & 5.0 & 21.0 & 28.0 & 35.0 \\
\hline \multirow[t]{2}{*}{$\begin{array}{l}\text { Ceiling on the outstanding stock of nonconcessional } \\
\text { external debt with a maturity of less than one } \\
\text { one year by the central government }{ }^{5,7}\end{array}$} & 0.0 & 0.0 & 0.0 & $\cdots$ & 0.0 & 0.0 & 0.0 & 0.0 \\
\hline & \multicolumn{8}{|c|}{ (Millions of euros) } \\
\hline $\begin{array}{l}\text { Floor on net international reserves of the } \\
\text { Bank of Cape Verde }(\mathrm{BCV})^{8}\end{array}$ & 41.2 & 43.0 & 53.0 & 248.6 & 12.6 & 25.3 & 36.8 & 50.6 \\
\hline $\begin{array}{l}\text { Memorandum item: } \\
\text { Program assumptions }\end{array}$ & \multicolumn{8}{|c|}{ (Billions of Cape Verde escudos) } \\
\hline $\begin{array}{l}\text { Nonproject external financial assistance, } \\
\text { including credit line (program assumption) }\end{array}$ & 3.0 & $\ldots$ & 2.9 & $\ldots$ & 0.6 & 1.2 & 1.8 & 2.4 \\
\hline External debt service & 2.6 & $\ldots$ & 2.3 & $\ldots$ & 0.7 & 1.3 & 2.0 & 2.6 \\
\hline Land sales & 2.0 & $\ldots$ & 1.6 & $\cdots$ & 0.7 & 1.4 & 2.1 & 2.8 \\
\hline Clearance of end-2006 stock of domestic arrears & 1.0 & $\ldots$ & 1.3 & $\ldots$ & 0.4 & 0.8 & 1.1 & 1.5 \\
\hline
\end{tabular}

${ }^{1}$ Quantitative assessment criteria and benchmarks are described in the technical memorandum of understanding.

${ }^{2}$ For purposes of calculating program adjusters, foreign currency amounts will be converted at current exchange rates.

${ }^{3}$ Excluding borrowing for clearance of arrears and net late payments. The ceiling will be adjusted downward (upward) by the cumulative downward (upward) deviations in external debt service, and upward (downward) by the cumulative downward (upward) deviation in nonproject external financial assistance and land sales relative to program assumptions.

${ }^{4}$ The ceiling will be adjusted downward (upward) by the cumulative downward (upward) deviations in external debt service and upward (downward) by the cumulative downward

(upward) deviation in nonproject external financial assistance relative to program assumptions.

${ }^{5}$ This assessment criterion is on a continuous basis.

${ }^{6}$ This assessment criterion applies not only to debt as defined in point No. 9 of the Guidelines on Performance Criteria with Respect to Foreign Debt (Decision No. 12274-(00/85), August 24, 2000), but also commitments contracted or guaranteed for which value has not been received. Excluded from this performance criterion are rescheduling arrangements, the Portuguese credit line, and borrowings from the Fund.

${ }^{7}$ The term "debt" has the meaning set forth in point No. 9 of the Guidelines on Performance Criteria with Respect to Foreign Debt. Excluded from this performance criterion are rescheduling arrangements, the Portuguese credit line, borrowings from the Fund, and normal import-related credits.

${ }^{8}$ The floor on net international reserves of the Bank of Cape Verde will be adjusted upward (downward) by the cumulative downward (upward) deviations in external debt service, and downward (upward) by the cumulative downward (upward) deviations in nonproject external financial assistance relative to program assumptions. 
2. Cape Verde: Structural Assessment Criteria and Benchmarks for 2007-08 ${ }^{1}$

Objectives

Conditionality

Timing

Status

\section{Structural Assessment Criteria}

Reduce fiscal risks

Reduce fiscal risks

Improve fiscal policy execution
Fully apply mechanisms for setting and adjusting electricity, water, and fuel prices (LOI \12).

Finalize and publish the mechanism for setting base utility tariffs (LOI 95 ).

Complete a formal mid-year review of revenue and expenditure developments that allows for taking corrective actions if necessary.

\section{Structural Benchmarks}

Improve budget Instituting November 30 as deadline for granting control new spending commitments to reduce end year payment pressure.

Strengthen tax administration

Strengthen the tax base

Strengthen the tax base

Strengthen the tax base

Reduce fiscal risks

Strengthen financial supervision Strengthen financial regulation

Strengthen financial regulation

Promote domestic and external stability
Finalize reform strategy for the General Tax Directorate (DGCl).

Submit the new General Tax Code to the National Assembly (LOI ๆ5).

Submit the new Code on Judicial Process to the National Assembly (LOI ๆ5).

Submit the draft individual and corporate income tax bills to the National Assembly (LOI ๆ5).

Finalize and publish a revised mechanism for adjusting petroleum prices (LOI $\$ 12$ ).

Submit to the National Assembly legislation to establish a Financial Intelligence Unit (LOI \5).

Submit to the National Assembly legislation to criminalize financing of terrorism and facilitate the combating of financing of terrorism ( $\mathrm{LOI}$ T5).

Submit to the National Assembly legislation to strengthen the framework for combating money laundering ( $\mathrm{LOI}$ 円5). $(\mathrm{MTFF})^{4}$ to the Council of Ministers in the 2009 budget preparation cycle and publish it on the
Continuous $^{2} \quad$ Not met

End-March 2008 Met

End-August

2008

\section{End-October Met}

2007

End-Dec. $2007 \quad$ Met

End-Dec. 2007 To be

implemented in June $2008^{3}$

End-Dec. 2007 To be implemented in June $2008^{3}$

End-Dec. 2007 Postponed to

October 2008 (LOI 15$)$

End-March 2008 To be implemented in June 2008

End-March 2008 Met

End-March 2008 To be implemented in June $2008^{3}$

End-March 2008 To be implemented in June $2008^{3}$

\section{New Structural Benchmarks introduced during the $4^{\text {th }}$ PSI review}

Submit a simplified medium-term fiscal framework November 2008 Ministry of Finance website (LOI $\llbracket 8$ ). 
Promote financial stability
Prepare a quarterly report on developments on balance of payments flows, including an assessment of interest sensitivity of non-resident flows into the banking system (LOI $\$ 11)$.

\section{${ }^{1}$ Updated during the $4{ }^{\text {th }}$ PSI review.}

${ }^{2}$ Through end-May 2008, following the coming into effect of the new base utilities tariffs and fuel price mechanisms.

${ }^{3}$ Submitted to the Council of Ministers in May 2008.

${ }^{4}$ The simplified MTFF will specify the annual revenues, expenditures, domestic financing, and external financing for the next three years. 


\section{Attachment. Technical Memorandum of Understanding ${ }^{1}$}

1. This memorandum sets out the understandings between the Cape Verdean authorities and the IMF staff regarding the definition of assessment criteria and indicative targets and reporting requirements for the fifth and sixth reviews under the Policy Support Instrument.

\section{QUANTITATIVE ASSESSMENT CRITERIA AND INDICATIVE TARGETS}

\section{A. Net Domestic Borrowing Excluding for Clearance of Arrears and Net Late Payments}

\section{Net domestic borrowing excluding for clearance of arrears and net late}

payments is defined as the cumulative change since the start of the calendar year of the net credit to the central government from the banking and nonbanking sectors less (1) the cumulative clearance during the calendar year of the stock of arrears as of the end of the previous year and (2) the cumulative payments during the first three months of the calendar year of expenses authorized by the previous year's budget, and plus the expenses accrued during the current year that will be paid during the first three months of the next calendar year as provisioned for in the budget law (late payments or atrasados). The ceiling will be adjusted downward (upward) by the cumulative downward (upward) deviations in external debt service and upward (downward) by the cumulative downward (upward) deviations in nonproject external financial assistance and land sales relative to program assumptions.

\section{Net credit to the central government from the banking and nonbanking system is}

defined as the overall position of the main central government institutions vis-à-vis the banking and nonbanking system - that is, the stock of all outstanding claims on the central government (loans, advances), and all other government debt instruments, such as long-term government securities) held by the central bank, commercial banks, and nonbank institutions, less all deposits held by the central government with the central bank and with commercial banks. The INPS is not included in central government accounts. Net credit to the central government excludes claims on the Trust Fund (TCMFs).

4. Reporting requirements. Data on the implementation of the budget compiled by the Ministry of Finance and Public Administration will be provided on a quarterly basis, to be submitted not later than five weeks after the end of each quarter, including (i) government domestic revenue by category; (ii) external budget support grants; (iii) government expenditure, including primary current expenditure, domestic and external interest payments, and capital expenditure, including domestically and budget support financed capital expenditure and estimates of externally project financed capital expenditure; (iv) the gross payment and gross accumulation of domestic accounts payable (atrasados); (v) the gross payment and gross accumulation of domestic payments arrears; (vi) external loan receipts

\footnotetext{
${ }^{1}$ Updated from the Country Report No. 08/37. Changes to paragraphs 2, 18, and 19.
} 
and principal payments; (vii) external arrears payments and accumulation; (viii) bank and nonbank financing; (ix) privatization and land sale receipts; and (x) any other revenue, expenditure, or financing not included above.

5. For the purposes of this memorandum, privatization and land proceeds will be understood to mean all monies received by the government from the sale or concessioning of a public company, organization, or facility to a private company or companies, organization(s), or individual(s), as well as any proceeds generated from the sale of government land and the liquidation of a public company, less restructuring costs.

\section{B. Net Domestic Assets of the Central Bank}

6. The ceiling on the cumulative change, from the beginning of calendar-year 2006, in net domestic assets of the $\mathrm{BCV}$ constitutes an assessment criterion. Net domestic assets (NDA) of the $\mathrm{BCV}$ are defined as reserve money minus net foreign assets of the $\mathrm{BCV}$, evaluated at the current end-of-period exchange rates. The program ceilings for NDA will be adjusted downward (upward) by the cumulative downward (upward) deviations in external debt service and upward (downward) by the cumulative downward (upward) deviations in nonproject external financial assistance relative to program assumptions. For purposes of calculating the adjusters, these flows will be valued at current exchange rates. Reserve money comprises bank reserves and deposits of the monetary institutions and private sector with the central bank, as well as cash in circulation.

7. Reporting requirements. The preliminary monthly balance sheets of the $\mathrm{BCV}$ and the consolidated commercial banks will be transmitted on a monthly basis, with a maximum delay of five weeks. The definitive version of the monthly balance sheet of the BCV will be provided as soon as available.

\section{Ceiling on Nonconcessional External Debt Contracted or Guaranteed by the Central Government}

8. Under the program, ceilings on medium- and long-term, as well as on short-term, nonconcessional external debt constitute assessment criteria. The ceiling on medium- and long-term nonconcessional external debt is on a quarterly basis while the one on short-term nonconcessional external debt is on a continuous basis. Nonconcessional external debt is defined as debt contracted or guaranteed by the central government with a grant element of less than 35 percent, calculated using currency-specific commercial interest reference rates (CIRRs) published by the Development Assistance Committee of the Organization for Economic Cooperation and Development (OECD). Debt rescheduling and debt reorganization are excluded from the limits on nonconcessional external debt. The limits on new nonconcessional external debt contracted or guaranteed by the central government (excluding borrowing from the Fund) are specified in Table 1 of the Letter of Intent. The definition of short-term nonconcessional external debt excludes normal short-term (less than one year) import-related financing. The Portuguese government's precautionary credit line in 
support of the exchange rate peg is also excluded from the definition of nonconcessional external debt. The assessment criterion on medium- and long-term nonconcessional external indebtedness applies not only to debt as defined in point No. 9 of the Guidelines on Performance Criteria with Respect to Foreign Debt (Decision No. 12274-(00/85), 8/24/00) but also to commitments contracted or guaranteed for which value has not been received. With respect to the assessment criterion on short-term nonconcessional external indebtedness, the term "debt" has the meaning set forth in point No. 9 of the Guidelines on Performance Criteria with Respect to Foreign Debt (Decision No. 12274-(00/85), 8/24/00).

9. Reporting requirements. The government of Cape Verde will consult with Fund staff before assuming any liabilities in circumstances where they are uncertain whether the instrument in question falls under the assessment criterion. Details of all new external debt (including government guarantees), indicating terms of debt and creditors, will be provided on a quarterly basis within five weeks of the end of each quarter.

\section{Net International Reserves of the Central Bank}

10. The floor on the cumulative change, from the beginning of calendar-year 2006, in net international reserves (NIR) of the BCV constitutes a assessment criterion under the program. The NIR of the BCV are defined as gross international reserves of the BCV net of its external reserve liabilities, calculated at the current exchange rates. Gross reserves of the $\mathrm{BCV}$ are those that are readily available (i.e., liquid and marketable and free of any pledges or encumbrances), controlled by the BCV and held for the purposes of meeting balance of payments needs and intervening in foreign exchange markets. They include gold, holdings of SDRs, the reserve position at the IMF, holdings of foreign exchange and traveler's checks, demand and short-term deposits at foreign banks abroad, fixed-term deposits abroad that can be liquidated without penalty, and any holdings of investment-grade securities. External liabilities of the BCV comprise liabilities to nonresidents contracted by the BCV with an original maturity of less than a year, any net off-balance-sheet position of the BCV (futures, forwards, swaps, or options) with either resident and nonresidents, any arrears on principal and interest to external creditors and suppliers, and purchases from the IMF. The program floors for the NIR will be adjusted upward (downward) by the cumulative downward (upward) deviations in external debt service and downward (upward) by the cumulative downward (upward) deviations in nonproject external financial assistance relative to program assumptions. For purposes of calculating the adjusters, these flows will be valued at current exchange rates.

11. Reporting requirements. A table on the NIR prepared by the BCV will be transmitted on weekly basis, with a maximum delay of two weeks.

\section{E. Nonaccumulation of New Domestic Payments Arrears}

12. As part of the program, the government will not accumulate any new domestic payments arrears. This will be monitored through the monthly execution of the cash-flow 
plan and the corresponding release of budget appropriations. For programming purposes, a domestic payment obligation to suppliers is deemed to be in arrears if it has not been paid within the normal grace period of 60 days (30 days for government salaries and debt service) or such other period either specified by the budget law or contractually agreed with the supplier after the verified delivery of the concerned goods and services, unless the amount or the timing of the payment is subject to good faith negotiations between the government and the creditor.

13. Reporting requirements. The Ministry of Finance and Public Administration, through the D.G.T., will submit on a quarterly basis a detailed table of the stock of domestic payments arrears, including the accumulation, payment, rescheduling and write-off of domestic payments arrears during the quarter. The data are to be provided within four weeks after the end of the quarter.

\section{F. Nonaccumulation of External Payments Arrears}

14. As part of the program, the government will not accumulate any new external payments arrears on a continuous basis. This will be monitored through the monthly execution of the cash-flow plan and the corresponding release of budget appropriations.

15. External arrears are defined as total external debt-service obligations of the government that have not been paid by the time they are due, except where agreements between the government and creditors explicitly provide for a grace period after such obligations falling due. External arrears exclude arrears on external debt, pending the conclusion of debt-rescheduling agreements.

16. Reporting requirements. Data on (i) debt-service payments; and (ii) external arrears accumulation and payments will be transmitted on a quarterly basis by the Ministry of Finance and Public Administration, within five weeks of the end of each quarter. In addition, the government will inform the Fund staff immediately of any accumulation of external arrears.

\section{STRUCTURAL ASSESSMENT CRITERIA ${ }^{2}$}

\section{A. Finalize and publish the mechanism for setting base utility tariffs}

17. The condition for finalizing and publishing the mechanism for setting base electricity and water tariffs will be deemed complete when (i) the technical specifications have been agreed upon between Electra and the autonomous Economic Regulatory Authority (ARE); (ii) the details of the base tariff setting mechanism have been published; and (iii) base tariff levels are brought in line with the agreed mechanism.

\footnotetext{
${ }^{2}$ See Table 2 of the Letter of Intent of June 2008.
} 


\section{B. Continuous application of the mechanisms for setting and adjusting electricity, water, and fuel prices}

18. The condition will be deemed met when (i) base utility tariffs are set, and reset with the periodicity, as specified in the agreed base tariff setting mechanism; (ii) between resetting of base tariffs, utility tariffs are adjusted whenever input costs since the last adjustment have changed cumulatively by more than three percent as specified in the published utility tariff adjustment mechanism; and (iii) within one month of each import shipment of petroleum products, retail petroleum product prices are adjusted and brought in line with the specifications in the retail petroleum price adjustment mechanism. This structural assessment criterion applies continuously only through end-May 2008, after which the new base utility tariffs and fuel price mechanisms will come into effect.

\section{Complete a formal mid-year review of revenue and expenditure that allows for taking corrective measures if necessary}

19. This condition will be deemed met when (i) revenue, expenditure, and financing during January-June are assessed and compared with budget forecasts; and (ii) the necessary corrective actions, if any, are identified.

\section{OTHER DATA REQUIREMENTS FOR PROGRAM-MONITORING PURPOSES}

20. Data on exports and imports, including volume and prices and compiled by the Director of Customs and the BCV, will be transmitted on a quarterly basis within five weeks after the end of each quarter. A preliminary quarterly balance of payments, compiled by the $\mathrm{BCV}$, will be forwarded within five weeks after the end of each quarter. 
INTERNATIONAL MONETARY FUND

\section{CAPE VERDE}

\section{Staff Report for the 2008 Article IV Consultation and}

Fourth Review Under the Policy Support Instrument—Informational Annex

Prepared by the African Department

(In consultation with other departments)

Approved by David Nellor and Mark Plant

June 9, 2008

- Relations with the Fund. Describe financial and technical assistance by the Fund and provides information on the safeguards assessment and exchange rate system. At end-March 2008, outstanding PRGF loans amounted to SDR 8.5 million ( 89 percent of the quota).

- Joint IMF-World Bank Management Action Plan. Presents the Implementation Matrix.

- $\quad$ Statistics Issues. Describes the availability and quality of macroeconomic statistics; and its usefulness for surveillance. 


\section{Cape Verde-Fund Relations}

(As of March 31, 2008)

I. Membership Status: Joined: November 20, 1978;

$\underline{\text { Article VIII }}$

II. General Resources Account:

SDR Million

\%Quota

Quota

9.60

100.00

Fund holdings of currency

9.59

99.93

Reserve position

0.02

0.17

Holdings exchange rate

III. SDR Department:

SDR Million

\%Allocation

0.62

100.00

Net cumulative allocation

0.07

11.27

IV. Outstanding Purchases and Loans:

PRGF arrangements

SDR Million

\%Quota

8.52

88.72

\section{Latest Financial Arrangements:}

Date of

PRGF $\stackrel{\text { Type }}{ }$

Stand-By
Arrangement

Apr 10, 2002

Feb 20, 1998
Expiration

Date

Jul 31, 2005

Mar 15, 2000
Amount Approved
(SDR Million)
8.64
2.50

Amount Drawn

$\underline{(\text { SDR Million) }}$

8.64

0.00

VI. Projected Payments to Fund

(SDR Million; based on existing use of resources and present holdings of SDRs):

Forthcoming

Principal

Charges/interest

Total

${ }^{1}$ When a member has overdue financial obligations outstanding

\begin{tabular}{lllll}
$\frac{2008}{0.49}$ & $\underline{2009}$ & $\underline{2010}$ & $\underline{2011}$ & $\underline{2012}$ \\
$\underline{0.05}$ & 0.98 & 1.48 & 1.73 & 1.61 \\
0.54 & $\underline{0.05}$ & $\underline{0.05}$ & $\underline{0.04}$ & $\underline{0.03}$ \\
\hline & 1.04 & 1.53 & 1.77 & 1.64
\end{tabular}

arrears will be shown in this section.

VII. Implementation of HIPC Initiative: Not Applicable

VIII. Implementation of Multilateral Debt Relief Initiative (MDRI): Not Applicable

\section{Safeguards Assessments}

Under the Fund's safeguards assessment policy, the Bank of Cape Verde (BCV) is subject to a voluntary assessment with respect to the Policy Support Instrument (PSI) approved on July 31,2006 . The necessary documentation has been received from the authorities and the assessment is underway. 
The previous BCV safeguards assessment was completed in December 2002 for the PRGF arrangement approved on April 10, 2002. The assessment concluded that substantial risks may have existed at the time in the bank's financial reporting framework, internal audit mechanism, and system of internal controls. While all recommendations but one have been confirmed as implemented by the BCV authorities, the audit opinion of external auditors on the 2005 and 2006 financial statements and the 2004 management letter indicates that further steps need to be taken.

\section{Exchange Arrangements}

The de facto and de jure exchange rate arrangement of Cape Verde is a conventional fixed peg. The escudo has been pegged to the euro at a rate of CVE 110.3 per $€ 1$ since January 4, 1999. Cape Verde accepted the obligations of Article VIII of the Articles of Agreement effective July 1, 2004. It maintains an exchange system that is free of restrictions on the making of payments and transfers for current international transactions.

\section{Previous Article IV Consultation and PSI Reviews}

Discussions for the 2006 Article IV consultation and on a medium-term economic program that could be supported by a three-year PSI were held in Praia April 28-May 16, 2006. The Executive Board concluded the Article IV consultation and approved the request for a PSI on July 31, 2006 (Country Report No. 06/334); the first PSI review on January 19, 2007 (Country Report No. 07/44); the second PSI review on May 7, 2007 (Country Report No. 07/223); and the third PSI review on December 21, 2007 (Country Report 08/37) (see www.imf.org).

\section{Technical Assistance}

Since 1985 the Fund has provided technical assistance to the BCV, the Ministry of Finance, and more recently the National Institute of Statistics in several areas: (i) MCM provided technical assistance to the BCV on organization and methods, management of external debt, monetary and banking statistics, accounting, credit, foreign exchange operations, management of public debt, and the separation of the functions of the Bank, as well as on the choice of exchange rate regime. BCV has also received technical assistance from STA on monetary and balance of payments statistics. (ii) The Ministry of Finance has received technical assistance from FAD on organization and budgetary procedures, budgeting, tax policy, and tax administration; from STA on fiscal accounting; and from LEG on tax legislation. (iii) The National Institute of Statistics has received technical assistance in national accounts and price statistics. Cape Verde is a participant in STA's GDDS Regional Project for Lusophone Africa, and its metadata were posted on the DSBB in February 2004. It is now receiving technical assistance to implement the GDDS plan for improvement.

Most recently, technical assistance has been provided in the following areas: 
FAD

- June 2004 visit to help the authorities move to a VAT, rationalize the import tariff, and overhaul the domestic indirect tax system. Many visits and a two-year resident advisor have gone into this effort.

- October 2004, mission to review tax administration, including VAT implementation, and a mission to help assess tax exemptions and incentives.

- September 2005, mission to assess tax exemptions and incentives.

STA

- National accounts (November 2003 and January-February 2006), balance of payments statistics (February 2004), government finance statistics (March 2004, April 2006, February-March 2007), price statistics (June 2004, May-June 2006, October 2007), and monetary statistics and reporting (March 2007).

\section{$\mathrm{MCM}$}

- Accounting, financial sector regulation, monetary operations and liquidity management (April and May 2004); banking supervision, liquidity management, exchange regime and reserves management (November 2005, March-April 2006, June 2006, November 2006, July 2007).

- Macro-prudential indicators (March 2008)

LEG

- Tax legislation (several missions October 2006-March 2008).

- AML/CFT initial assessment (March 2007), and legal drafting (March 2008).

XIII. Resident Representative: None. 
Cape Verde-Joint IMF-World Bank Management Action Plan

Implementation Matrix

\begin{tabular}{|c|c|c|c|}
\hline Title & Products & $\begin{array}{c}\text { Provisional Timing of } \\
\text { Missions }\end{array}$ & Expected Delivery Date \\
\hline \multicolumn{4}{|c|}{ A. Mutual information on relevant work programs } \\
\hline $\begin{array}{l}\text { Bank work program in } \\
\text { the next } 12 \text { months }\end{array}$ & $\begin{array}{l}\text { Lending: } \\
\text { - PRSC-4 } \\
\text { - PRSC-5 } \\
\text { - Roads Project-2 } \\
\text { - GEF (windmill farm) } \\
\text { - Growth and } \\
\text { Competitiveness project } \\
\text { (will finance the Master } \\
\text { Plan for Tourism) } \\
\text { Analytical and advisory } \\
\text { activities: } \\
\text { - Poverty assessment (will } \\
\text { include analysis of } \\
\text { unemployment and labor } \\
\text { market issues ) } \\
\text { - PPIAF/TA on the energy } \\
\text { sector (assessment of new } \\
\text { fuel pricing and utilities } \\
\text { tariff structure; Electra } \\
\text { management model) }\end{array}$ & $\begin{array}{l}\text { April } 2008 \\
\text { November } 2008 \\
\text { November } 2008 \\
\text { July } 2008 \\
\text { September } 2008 \\
\text { November } 2008 \\
\text { July } 2008 \\
\text { January } 2009 \\
\text { April } 2008\end{array}$ & $\begin{array}{l}\text { Board meeting July } 2008 \\
\text { FY09 (tentatively) } \\
\text { FY09 (tentatively) } \\
\text { September/October } 2008 \\
\text { October } 2008\end{array}$ \\
\hline
\end{tabular}




\section{Cape Verde: Joint Management Action Plan-Implementation Matrix (concluded)}

\begin{tabular}{|c|c|c|c|}
\hline Title & Products & $\begin{array}{c}\begin{array}{c}\text { Provisional Timing of } \\
\text { Missions }\end{array} \\
\end{array}$ & Expected Delivery Date \\
\hline \multicolumn{4}{|c|}{ A. Mutual information on relevant work programs } \\
\hline $\begin{array}{l}\text { IMF work program in } \\
\text { next } 12 \text { months }\end{array}$ & $\begin{array}{l}\text { Article IV consultation } \\
\text { PSI program, 5th review } \\
\text { PSI program, 6th review }\end{array}$ & $\begin{array}{l}\text { Mission in March } 2008 \\
\text { Mission in September } \\
2008 \\
\text { Mission in February } 2009\end{array}$ & $\begin{array}{l}\text { Board meeting May 30, } 2008 \\
\text { (expected) } \\
\text { Board meeting mid-November } \\
2008 \\
\text { Board meeting end-April } 2009\end{array}$ \\
\hline \multicolumn{4}{|c|}{ B. Requests for work program inputs } \\
\hline $\begin{array}{l}\text { Fund request to Bank } \\
\text { (with summary } \\
\text { justification) }\end{array}$ & $\begin{array}{l}\text { Public Expenditure Review } \\
\text { (PER) update to provide } \\
\text { quantitative inputs for } \\
\text { budget framework }\end{array}$ & & April 2008 \\
\hline $\begin{array}{l}\text { Bank request to Fund } \\
\text { (with summary } \\
\text { justification) }\end{array}$ & $\begin{array}{l}\text { TA on PFM and tax } \\
\text { exemptions }\end{array}$ & FY09 & \\
\hline \multicolumn{4}{|c|}{ C. Agreement on joint products and missions } \\
\hline $\begin{array}{l}\text { Joint products in next } \\
12 \text { months }\end{array}$ & $\begin{array}{l}\text { DSA update } \\
\text { FSAP } \\
\text { JSAN of PRSP-II }\end{array}$ & $\begin{array}{l}\text { IMF PSI } 5^{\text {th }} \text { review } \\
\text { August } 2008 \\
\qquad \text { FY09 }^{1}\end{array}$ & $\begin{array}{l}\text { October } 2008 \\
\text { June } 2009 \\
\text { June } 2008\end{array}$ \\
\hline
\end{tabular}

${ }^{1}$ Exact timing subject to confirmation. 


\section{CAPE VERDE-STATISTICS ISSUES}

21. The quality of economic and financial data provided to the Fund is generally adequate for surveillance and program monitoring, although there is a need for substantial improvements in some areas. Economic data are available in official websites www.minfin.cv, www.bcv.cv, and www.ine.cv. Weaknesses in the fiscal data make it difficult to monitor some aspects of fiscal performance; they include large statistical discrepancies, noncompliance with best accounting practices, and shortcomings in institutional coverage and sectorization. Other shortcomings of concern are weaknesses in the national accounts, a lack of short-term activity indicators besides the confidence barometer, and gaps in the tracking of large external flows - notably FDI, emigrant deposits, and remittances. Cape Verde has participated in the GDDS since February 2004. The metadata of the monetary and financial sector were updated in August 2007.

22. The authorities are taking steps to strengthen statistics, but the statistical system still suffers from a shortage of financial and human resources. A comprehensive master plan has been developed under the direction of the National Statistical Institute (INE), which assesses the need for upgrading the agencies that constitute the statistical system and outlines steps to broaden and improve all areas of statistics. The plan envisages improvements in data on national accounts (annual and quarterly), business statistics (including a new business census), demographic and social statistics (including a household survey to update the poverty profile), trade statistics (retail and international trade) macroeconomic indicators; labor market and sectoral statistics, and update of the CPI basket every five years. Cape Verde's development partners have already committed a substantial part of the estimated US\$15 million required to implement the plan through 2010.

\section{The country has benefited from STA technical assistance (TA) under the GDDS}

project for Lusophone Africa. The main purpose of this project was to help the government implement the GDDS plans for improvement, in particular the adoption of the Government Finance Statistics Manual 2001 (GFSM 2001). A first GFS mission visited the country in March 2004, with follow-up missions in April 2006 and March 2007. STA TA has also been provided in other areas, such as national accounts, consumer prices (with recent missions in May-June 2006 and October 2007 in preparation for the launch of the new CPI), monetary and financial statistics, and balance of payments statistics.

\section{Real sector}

24. Although some improvements have been made to the national accounts, significant weaknesses remain, including a lack of reliable demand-side GDP. The timeliness of the data has improved, with the INE releasing production and expenditurebased GDP data for 2002-03 in 2005 and providing production-based GDP estimates for 2004-06 to the mission in October 2007. However, the lag is still large by international standards. The base year for the constant price estimates, moreover, is outdated.

25. INE is currently working on a complete overhaul of the national accounts. It is updating the national accounts benchmark and base years from 1980 to 2002 and adopting 
the 1993 SNA. The objective is timely compilation of GDP by industry and expenditure categories at current and constant prices as well as institutional sector accounts.

26. INE will also introduce Tourism Satellite Accounts. These accounts will measure upstream linkages between the tourism sector and the rest of the economy and the import content of tourism exports.

\section{Full implementation of the $1993 \mathrm{SNA}$ would require a substantial improvement} in source data collection, for which capacity is currently lacking. The 2006 STA mission found a critical need to improve the timeliness and accuracy of national accounts source data, in particular the business survey. The capacity of INE staff working on national accounts was found to be overstretched; they assess in detail and correct individual source data entriessomething not undertaken in most countries by national accounts compilers. The statistical master plan will address many of these challenges.

28. A new CPI series was released in February 2008. The previous official CPI was based on weights dating back to 1989 , four years before imports were liberalized, which considerably changed consumption patterns. INE has had assistance from the National Statistics Institute of Portugal and benefited from STA CPI missions in May-June, 2006, October 2006, and October 2007, to support the introduction and dissemination of the revised $\mathrm{CPI}$. The new index has new weights and an updated commodity basket, and uses new compilation software.

29. Labor market statistics are weak. Data on unemployment are compiled with long delays and there are no wage data.

\section{Government finance}

30. Fiscal data has been improved. Benefiting from TA support under the GDDS project for Lusophone Africa, the Government Finance Statistics (GFS) compilation system is being upgraded. Most deposits previously held with commercial banks have been consolidated at the central bank. SIGOF, the Integrated Online Budget Management System, has been expanded to cover all semi-autonomous institutes and most municipalities by the end of 2007. In addition, a new chart of government accounts (PNCP) will be implemented in 2009 that adopts accrual accounting and double-entry principles. GFS are not reported for publication in the GFS Yearbook and International Financial Statistics.

31. Quality is a serious concern. The fiscal accounts are subject to large statistical discrepancies, flows and stocks are not consistent, and recording of arrears accumulation and clearance operations is not in line with best practices. Significant delay in donor reporting of project financing also affects the accuracy of fiscal data. Despite the recent revision of external debt data, significant weaknesses affect preparation of debt sustainability analyses. Multilateral debt statistics regularly differ from data received by creditors, and debt service projections cannot be reconciled with the debt stock. 


\section{Money and banking}

32. The quality of monetary and financial statistics is adequate, in terms of both accuracy and timeliness. A statistics mission undertaken in March 2007 helped BCV to finalized the standardized report forms (SRFs) for reporting monetary statistics to STA. SRFbased monetary data have been published in the IFS Supplement since June 2007. These data are fully aligned with the recommendations of the Monetary and Financial Statistics Manual. The mission also started building an integrated monetary database to meet STA, AFR, and BCV statistical needs. Currently, there are gaps in tracking the source and direction of changes in emigrant deposits, which cause difficulties in assessing the their interest sensitivity and gauging the appropriateness of the monetary policy stance.

\section{Balance of Payments}

33. With technical assistance from STA, the accuracy, periodicity, and timeliness of balance of payments statistics compiled by BCV have continued to improve. A greater use of surveys, combined with the International Transactions Reporting System implemented by the $\mathrm{BCV}$, has permitted a significant expansion of data sources and statistical coverage, which to a large extent, follow the recommendations of the 5th edition of the Balance of Payments Manual. Dissemination of quarterly BOP data on the BCV website has been regular and in 2007 the BCV resumed regular and timely transmission of these data to STA for publication in International Financial Statistics and in the Balance of Payments Statistics Yearbook (BOPSY). However, the BCV does not compile an International Investment Position. 


\section{Cape Verde: Common Indicators Required for Surveillance}

(As of April 30, 2008)

\begin{tabular}{|c|c|c|c|c|c|}
\hline & $\begin{array}{c}\text { Date of } \\
\text { Latest } \\
\text { Observation }\end{array}$ & $\begin{array}{l}\text { Date } \\
\text { Received }\end{array}$ & $\begin{array}{l}\text { Frequency } \\
\text { of Data }^{6}\end{array}$ & $\begin{array}{l}\text { Frequency } \\
\text { of } \\
\text { Reporting }^{6}\end{array}$ & $\begin{array}{l}\text { Frequency } \\
\quad \text { of } \\
\text { Publication }^{6}\end{array}$ \\
\hline Exchange Rates & 04/1/08 & 04/1/08 & $\mathrm{D}$ & $\mathrm{D}$ & $\mathrm{D}$ \\
\hline $\begin{array}{l}\text { International Reserve Assets } \\
\text { and Reserve Liabilities of the } \\
\text { Monetary Authorities }\end{array}$ & Nov-07 & Dec-07 & M & M & M \\
\hline Reserve/Base Money & Mar-08 & Apr-08 & M & M & M \\
\hline Broad Money & Mar-08 & Apr-08 & M & M & M \\
\hline Central Bank Balance Sheet & Mar-08 & Apr-08 & M & M & M \\
\hline $\begin{array}{l}\text { Consolidated Balance Sheet of } \\
\text { the Banking System }\end{array}$ & Mar-08 & Apr-08 & M & M & M \\
\hline Interest Rates ${ }^{2}$ & Mar-08 & Apr-08 & M & M & M \\
\hline Consumer Price Index & Feb-08 & Mar-08 & M & M & M \\
\hline $\begin{array}{l}\text { Revenue, Expenditure, Balance } \\
\text { and Composition of Financing } \\
\text { - General Government }\end{array}$ & $\mathrm{N} / \mathrm{A}$ & $\mathrm{N} / \mathrm{A}$ & $\mathrm{N} / \mathrm{A}$ & $\mathrm{N} / \mathrm{A}$ & $\mathrm{N} / \mathrm{A}$ \\
\hline $\begin{array}{l}\text { Revenue, Expenditure, Balance } \\
\text { and Composition of Financing }{ }^{3}- \\
\text { Central Government }\end{array}$ & Dec-07 & Feb-08 & Q & Q & Q \\
\hline $\begin{array}{l}\text { Stocks of Central Government } \\
\text { and Central Government- } \\
\text { Guaranteed Debt }\end{array}$ & Dec-07 & Feb-08 & Q & Q & Q \\
\hline $\begin{array}{l}\text { External Current Account } \\
\text { Balance }\end{array}$ & Q4-07 & Feb-08 & Q & Q & Q \\
\hline $\begin{array}{l}\text { Exports and Imports of Goods } \\
\text { and Services }\end{array}$ & Q4-07 & Feb-08 & Q & Q & Q \\
\hline GDP/GNP & 2006 & Oct-07 & A & A & A \\
\hline Gross External Debt & Dec-07 & Feb-08 & $Q$ & Q & Q \\
\hline $\begin{array}{l}\text { International Investment } \\
\text { Position }\end{array}$ & $\mathrm{N} / \mathrm{A}$ & $\mathrm{N} / \mathrm{A}$ & $\mathrm{N} / \mathrm{A}$ & $\mathrm{N} / \mathrm{A}$ & $\mathrm{N} / \mathrm{A}$ \\
\hline
\end{tabular}

${ }^{1}$ Includes reserve assets pledged or otherwise encumbered as well as net derivative positions.

${ }^{2}$ Both market-based and officially-determined, including discount rates, money market rates, rates on treasury bills, notes and bonds.

${ }^{3}$ Foreign, domestic bank, and domestic nonbank financing.

${ }^{4}$ The general government consists of the central government (budgetary funds, extra budgetary funds, and social security funds) and state and local governments.

${ }^{5}$ Including currency and maturity composition.

${ }^{6}$ Daily $(\mathrm{D})$, weekly $(\mathrm{W})$, monthly $(\mathrm{M})$, quarterly $(\mathrm{Q})$, annually $(\mathrm{A})$, irregular (I); and not available (NA) 


\section{INTERNATIONAL MONETARY FUND}

EXTERNAL

\section{Public Information Notice}

Public Information Notice (PIN) No. 08/80 FOR IMMEDIATE RELEASE

July 2, 2008
International Monetary Fund $70019^{\text {th }}$ Street, NW

Washington, D. C. 20431 USA

\section{IMF Concludes 2008 Article IV Consultation with Cape Verde}

On June 30, 2008, the Executive Board of the International Monetary Fund (IMF) concluded the Article IV consultation with Cape Verde and completed the fourth review of the Policy Support Instrument. ${ }^{1}$

\section{Background}

Over the last several years, Cape Verde has achieved a major economic transformation. Real per capita GDP has increased on average by over 7 percent a year, faster than other small island economies and other countries in sub-Saharan Africa. The unemployment rate fell by more than 10 percentage points between 2001 and 2006 . Cape Verde is also on track to achieve most of the MDGs by 2015, including halving the 1990 poverty level. This is remarkable for a small island economy with no natural resources. The transformation is reflected in an economy that is increasingly becoming service-based, led by tourism and commerce. In recognition of its strong performance and policy credibility, Cape Verde was accepted as a special partner of the European Union in November 2007, was invited to join the WTO in December 2007, and graduated from UN least-developed country (LDC) status in January 2008 (the second in sub-Saharan Africa after Botswana and the first graduation in more than a decade).

Policy implementation under the PSI is also strong. All PSI quantitative assessment criteria for end-December 2007 were met with wide margins. Revenues are ahead of the authorities' targets, and expenditures are as budgeted, which together have produced a

\footnotetext{
${ }^{1}$ Under Article IV of the IMF's Articles of Agreement, the IMF holds bilateral discussions with members, usually every year. A staff team visits the country, collects economic and financial information, and discusses with officials the country's economic developments and policies. On return to headquarters, the staff prepares a report, which forms the basis for discussion by the Executive Board. At the conclusion of the discussion, the Managing Director, as Chairman of the Board, summarizes the views of Executive Directors, and this summary is transmitted to the country's authorities. This PIN summarizes the views of the Executive Board as expressed during the June 30, 2008 Executive Board discussion based on the staff report.
} 
significant reduction in public debt. Official reserves are also building rapidly. Thus, domestic policies are strengthening the credibility of the exchange rate peg. Progress on structural measures in the program is steady, especially reforms related to public financial management, the tax system, the financial sector, and energy sector regulation.

On recent developments, economic growth is strong with moderate inflation. The real GDP growth rate peaked at 10.8 percent in 2006 , boosted by tourism, telecommunications, and construction. Based on information from the National Statistical Institute (INE), GDP growth is estimated at about 7 percent in 2007 and, factoring in the effects of the global economic slowdown, growth should moderate only slightly to $6 \frac{1}{2}$ percent in 2008 as tourism and construction continue to expand. With the peg to the euro and the high openness allowing rapid import price pass-through, twelvemonth inflation averaged about 31/2 percent for December 2007-April 2008, broadly in line with inflation in the euro area. While food and energy prices have risen, this has not led to generalized inflation partly due to lack of a strong wage indexation.

Fiscal policy continues to support the peg. Prudent implementation of the 2008 budget will ensure that domestic debt will be further reduced to 16 percent of GDP by end-2008. Tax revenues are exceeding budget forecasts, reflecting not just economic growth but also improvements in tax administration; also, asset sales have surpassed expectations. These factors, together with continued expenditure restraint, have reduced the domestic debt-to-GDP ratio. The authorities' target for domestic debt, 20 percent of GDP, was reached in 2007, two years ahead of schedule.

The Bank of Cape Verde (BCV) continues to conduct monetary management appropriately. Given the peg and a largely open capital account, passive monetary management by the BCV has been setting the official policy rate consistent with its endogenous equilibrium level, which smoothes and sterilizes short-term capital flows. Reserves continue to accumulate, and while FDI-related imports have led to and financed a higher current account deficit, there are no signs of a more general increase in imports that would jeopardize the targeted increase in reserves. Excess liquidity has been contained by sterilization, by the new investment opportunities on the Stock Exchange following rapid development of the domestic equity market, and by growth in private sector credit. The buildup of government deposits at the BCV is also helping to sterilize external inflows. Thus, monetary management and fiscal prudence are both supporting the exchange rate peg and promoting external stability.

Structural reforms are being undertaken to foster competition and enhance private sector's role in the economy. Several state-owned enterprises were privatized; the government selected new management to prepare the national airline (TACV) for privatization; and the process of privatizing the ports operator (ENAPOR) is underway. Ahead of WTO accession, external tariffs were lowered. The Cape Verde Stock Exchange has been revitalized; its market capitalization is now 25 percent of GDP (from zero in 2005). Cape Verde has also made major strides in the last several years in achieving the key objectives set out in the first Poverty Reduction Strategy (PRSP) and in improving the well being of its citizens. The second PRSP submitted to the IMF Board in June 2008 sets out Cape Verde's medium-term goals and provides a comprehensive and integrated strategy for achieving those goals. 


\section{Executive Board Assessment}

Executive Directors welcomed Cape Verde's impressive economic performance and policy implementation in recent years, reflected in the country's recent graduation from UN least-developed country status, accession to the WTO, and acceptance as a special partner in the EU. They commended the authorities for their prudent macroeconomic management and their commitment to the objectives of the PSI program. Directors welcomed the faster-than-expected reduction of domestic debt and buildup of official reserves. Prudent policies have catalyzed investment and export growth, especially in the tourism sector, contributing to robust growth and moderate inflation.

Directors agreed that Cape Verde's external stability appears to be well secured despite the recent increase in the current account deficit, as foreign direct investment is largely financing this deficit. They considered that the exchange rate peg has served the economy well, helping to achieve low inflation, and they took note of the staff assessment that the real effective exchange rate is broadly in line with fundamentals.

Looking ahead, Directors believed that continuing prudent fiscal policy will be critical to safeguarding the exchange rate peg and reducing Cape Verde's vulnerability to shocks. A medium-term fiscal strategy is needed to anchor expenditure and tax reform plans. Directors urged the authorities to publish a medium-term fiscal framework as part of the 2009 budget cycle. They noted that given the larger-than-expected reduction of domestic debt in 2007, the risk of debt distress remains low even with current plans to increase capital spending. At the same time, some Directors observed that the overall debt level, both domestic and external, remains relatively high, calling for continued prudence.

Directors considered that further strengthening the financial system will be important to safeguard its stability and enhance Cape Verde's growth prospects. They welcomed the measures being taken by the Central Bank of Cape Verde to strengthen financial sector regulation and supervision, including the recently published regulation that broadly aligns prudential requirements for both on- and offshore banks. At the same time, banks will need to broaden their source of funds to reduce their dependence on nonresident deposits. Directors looked forward to the forthcoming Financial Sector Assessment Program, which should strengthen the authorities' hand on these issues.

Directors noted that structural reforms are necessary to maintain external competitiveness and sustain high growth over the long term. They encouraged the authorities to move ahead with their structural reform agenda to diversify the economy and improve price flexibility. This will support private sector development and increase the economy's resilience to shocks. Directors welcomed the recent progress made on the regulatory framework for the energy sector, and urged the authorities to accelerate the implementation of their broader energy sector reform plan, especially in the area of the adjustment of energy prices.

Directors welcomed the new PRSP-II, as well as the progress that has been made in improving the well-being of Cape Verde's citizens. They encouraged the authorities to 
continue pursuing reforms consistent with the PRSP-II, and to improve further the assessments of the costs of the PRSP-II's expenditure plans. The identification of reliable and relevant poverty indicators, along with enhanced monitoring and evaluation of the PRSP-II's implementation, will help the authorities gauge the effectiveness of their efforts as they work to alleviate poverty and attain the Millennium Development Goals. It is expected that the next Article IV consultation with Cape Verde will be held within 24 months, subject to the provisions of the Executive Board decision on consultation cycles in program countries.

Public Information Notices (PINs) form part of the IMF's efforts to promote transparency of the IMF's views and analysis of economic developments and policies. With the consent of the country (or countries) concerned, PINs are issued after Executive Board discussions of Article IV consultations with member countries, of its surveillance of developments at the regional level, of post-program monitoring, and of ex post assessments of member countries with longer-term program engagements. PINs are also issued after Executive Board discussions of general policy matters, unless otherwise decided by the Executive Board in a particular case. 
Cape Verde: Selected Economic and Financial Indicators, 2004-08 ${ }^{1}$

\begin{tabular}{|c|c|c|c|}
\hline 2004 & 2005 & 2006 & $\frac{2007}{\text { Est. }}$ \\
\hline
\end{tabular}

(Percent change unless otherwise stated)

\section{National Accounts and Prices economy}

Real GDP growth

$$
6.5
$$

10.8

6.9

6.5

Real GDP (per capita)

Consumer prices (in percent, annual average)

0.4

5.4

4.4

Gross capital formation (percent of GDP)

38.9

41.0

43.0

42.6

45.0

Gross national savings (percent of GDP)

25.3

37.6

38.0

33.4

\section{Money and Credit}

Net foreign assets

31.9

Credit to the economy

Broad money (M2)

\section{Central Government}

Total domestic revenue (percent of GDP)

Total grants (percent of GDP)

Total expenditure (percent of GDP)

Overall balance (including grants, percent of GDP)

External debt (percent of GDP)

Net domestic debt (percent of GDP)

\section{External}

Exports of goods and services (local currency) Imports of goods and services (local currency)

$\begin{array}{rrrrr}5.3 & 23.9 & 35.0 & 14.1 & 20.9 \\ 6.5 & 0.5 & 23.4 & 17.9 & 13.9 \\ -3.0 & -2.5 & 2.7 & 1.3 & \ldots \\ 4.1 & 5.6 & 4.7 & 6.1 & 4.0 \\ -14.4 & -3.4 & -5.0 & -9.1 & -9.4\end{array}$

Real effective exchange rate (annual average)

Overall balance of payments (percent of GDP)

Current account balance (including current grants, percent of GDP)

Gross reserves (months of prospective imports)

External debt service (percent of exports)

Sources: Cape Verdean authorities; and IMF staff estimates and projections.

${ }^{1}$ As of June 4, 2008. 
Press Release No. 08/155

FOR IMMEDIATE RELEASE

International Monetary Fund

June 30, 2008

Washington, D.C. 20431 USA

\section{IMF Executive Board Completes Fourth Review Under the Policy Support Instrument for Cape Verde}

The Executive Board of the International Monetary Fund (IMF) today completed the fourth review under a three-year Policy Support Instrument (PSI) for Cape Verde. The PSI was approved on July 31, 2006 (see Press Release No. 06/172).

In completing the review, the Board granted a waiver for the non-observance of an assessment criterion related to application of the mechanism for setting and adjusting electricity, water, and fuel prices, given the strength of the authorities' policies and the corrective measures taken.

Cape Verde's PSI is designed to enhance the sustainability of growth and development by maintaining a stable macroeconomic environment and moving forward with structural reforms. It is also expected to help the country reduce macroeconomic risks, provide a margin for safety against shocks, and prepare for a possible longer-term decline in access to concessional external financing. Key measures are directed to reducing public debt, building up international reserves, improving public financial management, and strengthening financial sector and energy sector regulation.

Following the Executive Board's discussion, Mr. Takatoshi Kato, Deputy Managing Director and Acting Chair, stated:

"Cape Verde's impressive economic performance in recent years reflects both prudent macroeconomic management and economic reforms. Good policies have catalyzed investments and export growth, especially in the tourism sector-breaking past dependence on aid and remittances - leading to robust growth and moderate inflation.

"Continuation of prudent fiscal policy will be critical to safeguarding the exchange rate peg and enhancing resilience against shocks. The PSI target for domestic debt was met two years ahead of schedule, helping to build up foreign reserves faster and support the exchange rate peg. This success was due largely to restraint on current spending, improved public financial management, and robust tax revenues, reflecting improvements in tax administration. Going forward, the prudent 2008 budget is consistent with further reducing domestic debt. The forthcoming medium-term fiscal framework should help to anchor the authorities' expenditure and tax reform plans, preserve the low risk of debt distress, and help accumulate reserves to support the exchange rate peg and buffer shocks.

Washington, D.C. 20431 • Telephone 202-623-7100 • Fax 202-623-6772 • www.imf.org 
"Further strengthening the financial system will be important to safeguard its stability and enhance Cape Verde's growth prospects. The authorities are making progress in strengthening financial sector regulation and supervision, including the broad alignment of prudential requirements for both on- and offshore banks. Strong oversight of banking system soundness would help attract more diverse sources of financing and reduce dependence on nonresident deposits. The Central Bank of Cape Verde is working to strengthen the set of financial soundness indicators. The forthcoming FSAP should strengthen the authorities' hand and enable them to better understand real and financial sector linkages.

"Structural reforms to make the economy more flexible will be key to enhancing competitiveness and to sustaining high growth in the long term. Cape Verde's export base remains narrow. The ongoing tourism boom offers a window of opportunity to facilitate private sector development and enhance economic diversification. Diversifying the economy continues to be an important strategic goal to increase resilience to shocks.

"Cape Verde has made major strides in the last several years in achieving the key objectives set out in the first PRSP and in improving the well-being of its citizens. The PRSP-II sets out Cape Verde's medium-term goals and provides a comprehensive and integrated strategy for achieving them. Implementation of the PRSP-II would benefit from adequately costed expenditure plans for key priorities and an improved monitoring and evaluation system," $\mathrm{Mr}$. Kato said.

The IMF's framework for PSIs is designed for low-income countries (and small island states) that may not need, or want, IMF financial assistance, but still seek IMF advice, monitoring and endorsement of their policies. PSIs are voluntary and demand driven. PSIsupported programs are based on country-owned poverty reduction strategies adopted in a participatory process involving civil society and development partners and articulated in a Poverty Reduction Strategy Paper (PRSP). This is intended to ensure that PSI-supported programs are consistent with a comprehensive framework for macroeconomic, structural and social policies to foster growth and reduce poverty. Members' performance under a PSI is normally reviewed semi-annually, irrespective of the status of the program (see Public Information Notice No. 05/145). 


\section{Statement by Laurean W. Rutayisire, Executive Director for Cape Verde June 30, 2008}

1. We thank staff for the comprehensive and well-illustrated report and selected issues paper on Cape Verde as well as for the fruitful policy dialogue they continue to maintain with the country's authorities. The authorities appreciate the useful advice the Fund provides them in support of their efforts to overcome the policy challenges facing the country. As is customary, the authorities have consented to the Fund publication of their letter of intent, the staff report, and selected issues paper.

2. Cape Verde continues to make outstanding economic and policy achievements. Real GDP growth continued to be strong over recent years. Macroeconomic and external stability were consolidated, with inflation kept in check, domestic debt significantly reduced and the external position largely improved. Along with falling unemployment, the incidence of poverty continued to decline at a pace which, if maintained, should enable the country to significantly reduce extreme poverty, in line with the poverty MDG. Recently, Cape Verde earned a graduation from UN least-developed country status and a Special Partnership with the European Union.

3. Notwithstanding these accomplishments, the country continues to face a number of challenges. Poverty and unemployment are still high despite having embarked on a steeply declining path over the past several years. Growth performance is still hampered by a number of impediments such as drought and weather vagaries, weak infrastructure and, more recently, high food and energy prices. The authorities continue to show a strong resolve to convert these challenges into opportunities to accelerate growth and poverty reduction. And in this endeavor, they are hopeful that they will continue to benefit from the support of Cape Verde's international partners, notably the Fund.

\section{Recent Performance under the Policy Support Instrument}

4. Cape Verde continues to keep up with its strong performance under the PSI, thanks to sound macroeconomic and structural policies. Economic activity in 2007 was strong. In the face of rising energy and food price increases, real GDP growth remained strong, reaching about 7 percent. CPI inflation declined and is also expected to continue to follow its downward path this year. The external current account deficit peaked, due to higher FDIrelated imports, but was more than financed by foreign investment flows.

5. In regard to program performance, all quantitative assessment criteria were met, some of which with wide margins. These include the end-December 2007 criteria on net domestic borrowing and international reserves which were comfortably met. This program 
overperformance reflects, among others, strict fiscal discipline, strong country ownership of the PSI, improved tax administration, and prudent macroeconomic management. On the structural front, the authorities continued to implement most reforms set forth in the PSI program although some were carried out with delay primarily due to capacity constraints. In particular, such constraints prevented a timely implementation of the continuous assessment criterion on the full application of the mechanism for setting and adjusting fuel prices. However, the authorities promptly took corrective actions by adjusting fuel prices on March 25,2008 , and working to develop by the end of this month a new fuel pricing formula with the assistance of an international consulting firm. In light of these corrective actions, we call on Directors to support the authorities' request for waiver for the missed assessment criterion.

6. With the aim at broadening the tax base, the new General Tax Code and Judicial Process Code will be submitted to the National Assembly. Going forward, it is the authorities' intention to improve the efficiency of the tax system so as to make it more conducive to private sector development. Accordingly, the authorities will, in the coming months, submit the income tax bills to the National Assembly along with draft legislation aimed at streamlining tax incentives. With regard to financial sector reform, the authorities took vigorous steps towards strengthening financial supervision and regulation. In particular, anti-money laundering and CFT legislations were submitted to the National Assembly; so were legislations to establish a financial intelligence unit. Similarly, the authorities elaborated and published in March 2008 a mechanism for setting base utility tariffs, as part of the energy sector reforms which will help reduce fiscal risks.

\section{Reform and Policy Agenda}

7. It is appropriate that Article IV discussions focused on consolidating macroeconomic stability and enhancing the resilience of the economy to shocks. This focus is particularly opportune at a time when food and oil price increases pose an additional policy challenge to the authorities. Latest available evidence indicates that these price increases are starting to exert noticeable inflationary pressures in Cape Verde. A continuously high level of oil prices would likely have an adverse impact on growth, as confirmed by staff simulations, and the country's external position. The authorities took steps to identify appropriate policy response and to assist the most vulnerable households in their efforts to cope with these price rises. This assistance took the form of measures that include the reduction of import duties and value-added tax exemptions on some cereals. They are also considering ways of increasing agricultural output, notably through improvements in rural infrastructure. Going forward, it is their expectation that the Fund and other international institutions will provide the necessary assistance in support of their efforts to cope with the oil and food price shocks.

8. Implementation of the authorities' reform and policy agenda will continue to proceed according to the stated objectives of the PSI program. In 2007, domestic debt was reduced by 
9 percentage points of GDP, thereby prolonging the downward trend followed by this fundamental since the beginning of the PSI program and reaching the program original target, a net domestic-to-GDP ratio of 20 percent, two years ahead of schedule. With the prudent budget and policies set for 2008, the authorities expect to further consolidate this achievement.

9. Monetary policy will continue to be geared at helping further accumulate reserves with a view of supporting the exchange peg which remains appropriate. The targeted pace of this accumulation will be about 0.1 month of prospective imports per year, setting the stage for reaching over 4 months by 2013. The BCV intends to develop a system aimed at better monitoring external flows, including non-resident deposits, standing ready to change interest rates, if necessary, to prevent destabilizing capital flows.

10. My Cape Verdean authorities are committed to further improvements in public financial management. Notably, by November 2008, the authorities intend to develop, and submit for consideration by the Council of Ministers, a simplified medium-term fiscal framework which will be also put in the public domain. It is expected that this will pave the way for the adoption of a medium-term framework and investment program that adequately capture the authorities' intention to augment investments in infrastructure and the energy sector.

11. As the authorities attach high importance to safeguarding debt sustainability while pressing ahead with their investment program, improving debt management will also rank high on the authorities' agenda. This will require addressing existing capacity constraints and, to this end, the authorities would appreciate benefiting from Fund technical assistance.

12. In line with the authorities' commitment to strengthen the supervisory and regulator framework of the sector, the central bank, BCV, published in November 2007 a set of new prudential requirements for capital ratios, provisioning and loan classification, credit risk assessment, and credit concentration. Reflecting the health of the banking system, all resident banks currently comply with the new requirements. Going forward, the authorities will continue to closely monitor compliance with the new regulations.

13. The approval of the new base utility tariff mechanism will help reduce fiscal liabilities by allowing full recovery of the costs borne by the electricity and water company, Electra. The recent adjustment of fuel prices illustrates the authorities' determination to follow through their previous commitment under the PSI to exclude energy subsidies from the 2008 budget. As noted above, they intend to finalize and publish soon a streamlined and transparent fuel pricing formula. In anticipation of increased recourse to public private partnerships (PPPs) to finance planned large-scale investments, particularly in the energy sector, the authorities envisage to strengthen the regulatory framework for such PPPs. They are also attractive to greater involvement of the private sector in the management of the 
electricity company. This would be along the lines of other steps they are taking to promote private sector development, including business-friendly measures such as the reduction of the time necessary for creating a business and streamlining of the tax system.

\section{Conclusion}

14. Cape Verde's outstanding achievements over recent years have helped lift its population out of absolute poverty and strengthen the country's policy credibility. The authorities are hopeful that these achievements will be viewed by Cape Verde's development partners as a motive for stronger engagement rather than disengagement. In particular, it is their wish that the country's graduation from least-developed country status earlier this year will not lead to a premature shortage of concessional financing. The authorities welcome reassurances from most partners that their concessional assistance will not abruptly end going forward.

15. In light of the above, my Cape Verdean authorities will appreciate the Board's approval of their request for waiver for nonobservance of a structural assessment criterion and support for the completion of the fourth review of the PSI program. 